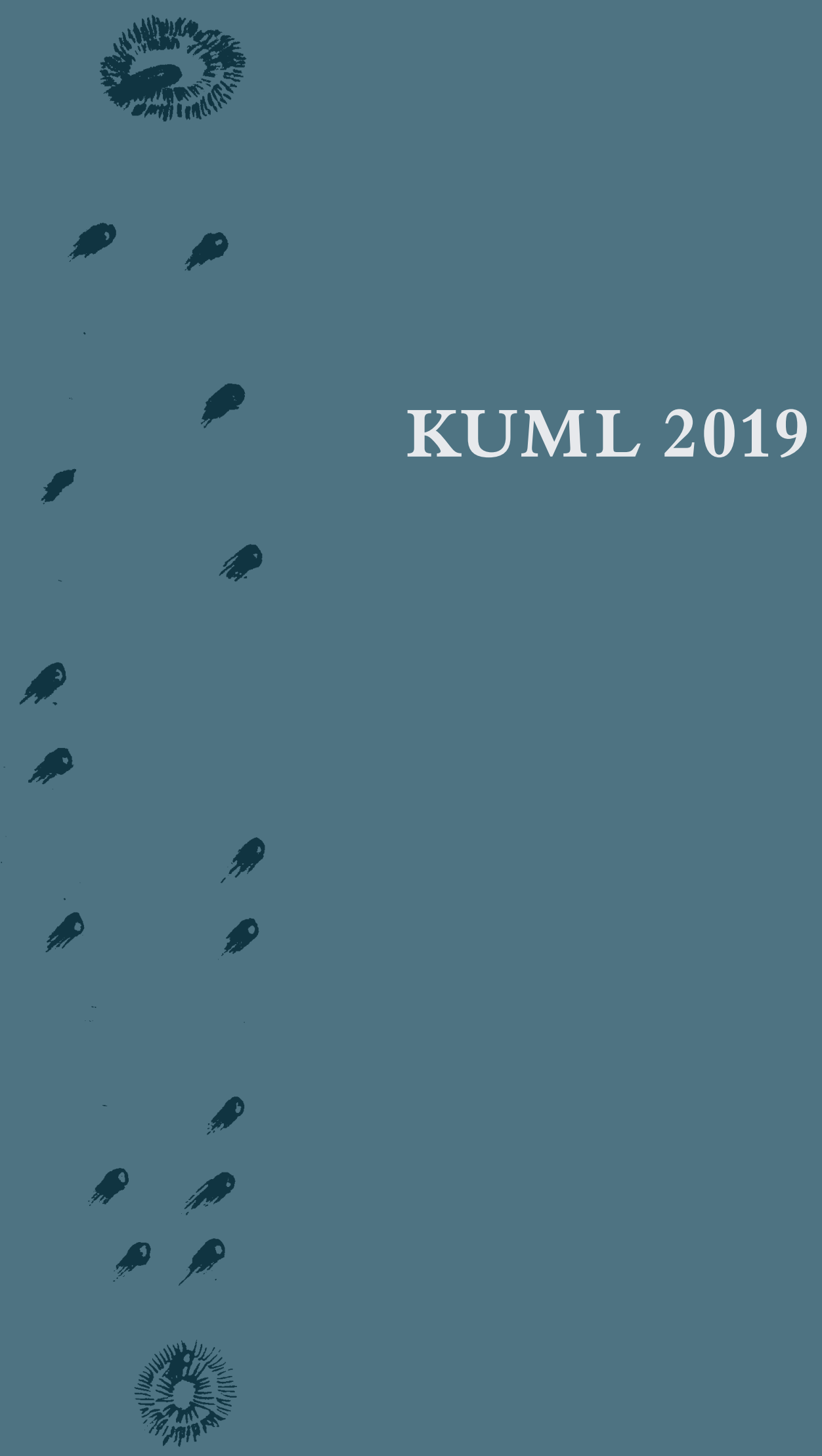

KUML 2019 


\section{KUML 2019}

Årbog for Jysk Arkæologisk Selskab

With summaries in English

I kommission hos Aarhus Universitetsforlag 


\section{Afviklingen af de middelalderlige klostre $\mathrm{i}$ Danmark og Nordtyskland}

Fra dansk side har der indenfor klosterforskningen været stor interesse for grundlæggelsen af landets mange forskellige klostre. Mindre interesse har knyttet sig til deres afvikling. På én måde kan man naturligvis sige, at klosterlivet sluttede med Reformationen, men i det mindste forsvandt bygningerne ikke med et snuptag. Tværtimod er der en kompliceret afvikling, som på mange måder er individuel for de enkelte klostre. ${ }^{1}$ Afviklingen, nedlæggelsen og ombygningerne af klosterbygningerne er dog uhyre væsentlig for mulighederne for gennem arkæologi og bygningsarkæologi at få kendskab til klostrenes udformning i middelalderen, hvor de var i brug. Nu hvor vi er begyndt at fejre 500-året for den lutherske Reformation, kunne dette være en anledning til at se på afviklingen af klostrene. Og i sammenhæng hermed kan det også være relevant at se på vilkårene uden for Danmark som i Nordtyskland, der nogenlunde samtidig overgik til den luthersk evangeliske kirkestruktur uden klostre.

Inden for klostervæsnet er det i grunden uhyre sjældent, at man drager sammenligninger mellem Danmark og Nordtyskland - her har man normalt kikket længere væk, hvilket igen hænger sammen med interessen for grundlæggelsestiden, hvor indflydelsen er kommet fra steder som England, Frankrig og Rhinområdet. Disse områder er dog ikke brugbare til sammenligninger om klostrene i forhold til Reformationen. I England skete der nemlig en voldsom forandring med The Suppression of the Monasteries fra 1536-40. Ikke nok med at godset blev inddraget og bygningerne ribbet for værdier, men også tagtømmeret blev fjernet og blytagene smeltet om. Ja selv vinduernes blysprosser blev smeltet om. Bygningerne skulle ikke let kunne sættes i stand igen. England har i virkeligheden kun relativt få middelalderlige klosterbygninger under tag $\mathrm{i}$ dag. I Centraleuropa, hvor temmelig mange klostre i øvrigt var helt ombygget i barokstil, blev klostrene nedlagt under den såkaldte oplyste enevælde, men i 
Frankrig var enevælden ikke særlig oplyst, så her skete intet, før alt eksploderede i Den Store Revolution. Også klosterlivet og klostrene gik under i et stort ødelæggelsesorgie. For England og Frankrig blev bruddet med den katolske tro helt fatalt for klosterkirker og -bygninger. Det kompenseres der så for takket være det meget store antal middelalderlige klostre, der har eksisteret i disse to lande og for Englands vedkommende også ved den tidlige og stærke interesse for klosterarkæologi.

Det skal i det følgende søges afdækket, hvorledes klostrene blev afviklet i de to områder, Danmark og Nordtyskland, med hensyn til ligheder og forskelle. I den forbindelse skildres selve Reformationens gennemførelse, som langt fra foregik på en ensartet måde, for at se på, i hvor høj grad denne begivenhed havde betydning for bygningernes skæbne og nuværende tilstand. For begge områder gælder det, at hvad bygningsvolumen i klostrene angår, var tiden før Reformationen højdepunktet. De mange klostre i Nordtyskland kan ikke enkeltvis behandles indgående i denne sammenhæng, men der vil dog være korte beskrivelser i tekst og billeder af nogle af disse klostre. ${ }^{2}$

I artiklen vil der med begrebet Nordtyskland specielt for landområderne blive fokuseret på landskaberne Mecklenburg og Pommern, der stort set har dækket den sydlige Østersøkyst fra Lübeck til Danzig. Det er de dele af Tyskland, som ligger nærmest Danmark, og hertil var der i middelalderen på forskellig måde tætte forbindelser. Det forekommer rimeligt, at de to hertugdømmer med klostre i byer såvel som på landet vil være en glimrende mulighed for sammenligninger med Danmark på klosterområdet under reformationstiden. $\mathrm{Nu}$ var Reformationen i Mecklenburg og Pommern ganske kompliceret med mange variationer og derfor interessant i sammenligning med Danmark, hvor der overordnet var en nogenlunde ensartet udvikling. Samtidig afspejler udviklingen i hertugdømmerne også den rodede situation i senmiddelalderens Tyskland med forskellige udviklinger i nærtliggende områder. I al almindelighed varierede Reformationens forandringer betydeligt fra region til region i Tyskland, samtidig med at mange områder forblev katolske.

Foruden de to nævnte hertugdømmer vil der i fremstillingen også blive inddraget udviklingen i de store hanseatiske byer som Hamburg, Lübeck, Lüneburg og Danzig og hertil mere kortfattet hertugdømmet Østpreussen. Byerne tilsluttede sig den lutherske reformation, men på forskellig vis og til forskellig tid. I Preussen var den lutheranske hertug Albrecht von Hohenzollern tidligere stormester for Den Tyske Orden og svigersøn til den danske konge Frederik I. Vejen til Reformationen for de to herskeres territorier var dog helt forskellig trods personernes slægtskab. 


\section{Den monastiske situation i senmiddelalderen}

\section{Danmark}

Klostervæsnet var i Danmark hovedsageligt et byfænomen. Ved Reformationen var 72 ud af 116 klostre placeret i byerne. ${ }^{3}$ Og det var langt hen ad vejen også et senmiddelalderligt fænomen med en fjerdedel af klostrene grundlagt efter 1400 (fig. 1). Interessen for at stifte nye klostre fortsatte næsten til begyndelsen af Reformationen herunder også med nogle mislykkede forsøg. Ved siden af konventerne i byerne blev der efter 1400 oprettet fire store klostre ude på landet - inklusiv de to birgittinerklostre i Maribo og Mariager. Mange af de nye klostre i byerne tilhørte den tredje tiggerorden, karmeliterne, eller Helligåndsordenen (fig. 2). Denne store interesse i at stifte nye klostre på dette tidspunkt er i det nordeuropæiske område helt unik for Danmark. ${ }^{4}$

Den kongelige familie i Danmark var gennem generationer betydningsfulde støtter for adskillige danske klostre. Af de 28 klostre grundlagt efter 1400 var i det mindste de 15 helt eller delvis stiftet af danske konger og dronninger. Specielt Christian I stod bag forskellige tiggerklostre og hospitaler. Han var endvidere ivrig for en reform blandt franciskanerne med overgang fra konventuale til observante konventer. ${ }^{5}$ Hvilket betød, at klostrene skulle vende tilbage til ordenens oprindelige strikse fattigdom. Dette var dog kun den ene side af kongens politik over for klostervæsnet.

Med hensyn til de gamle jordejende klostre var situationen lidt anderledes. Mange af dem blev pålagt at holde soldater og heste i tilfæelde af krig samt huse kongen og hans mænd, når de var på rejse. Hvis rettighederne ikke blev udnyttet, skulle klostret i stedet betale penge eller aflevere naturalier. I 1473 indsatte Christian eksempelvis også sin kansler som leder/prior af Sankt Clara Kloster i

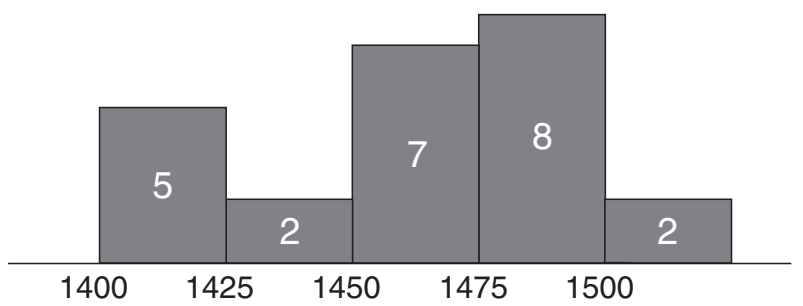

Fig. 1. Senmiddelalderlige klosterstiftelser i byerne angivet med 25 års intervaller fra år 1400 til reformationstidens uro i 1520 'erne. Der ses ikke nogen afmatning i stiftelsen af nye klostre frem gennem 1400-tallet. - Efter Krongaard Kristensen 2013.

Foundation of Late Medieval monasteries in the towns in 25-year intervals from 1400 to the uncertain times of the Reformation in the 1520s. No decline is evident in the founding of new monasteries through the course of the 15th century. 


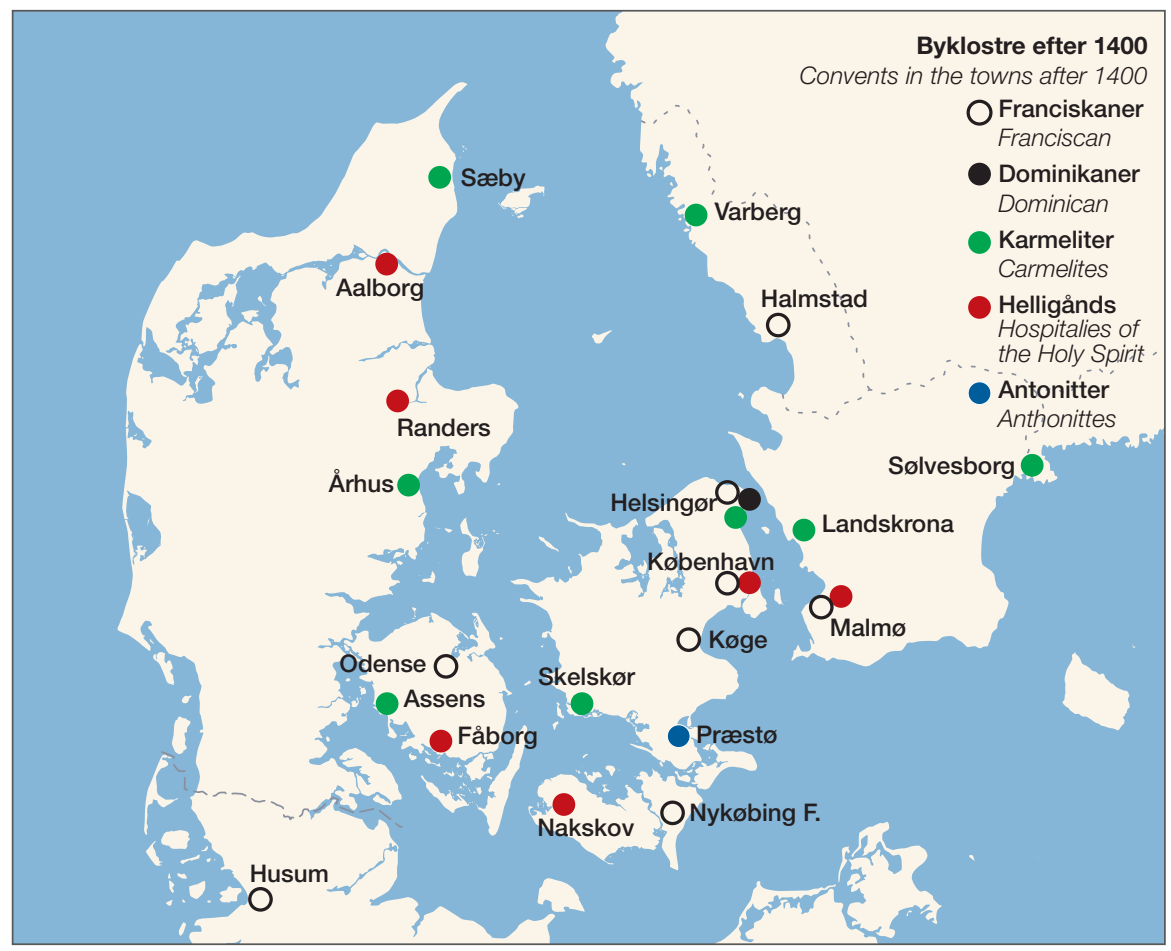

Fig. 2. Danske byklostre grundlagt efter 1400. Kortet viser to lidt modsat rettede tendenser: Dels at der stiftes en række klostre i byerne i landets yderområde, og dels at der stiftes klostre i byerne omkring Øresund, hvor der i forvejen var en hel del.

Danish urban monasteries established after 1400. The map shows two slightly opposing trends: On the one hand, several monasteries are founded in towns in the country's peripheral area, on the other, monasteries are established in the towns around the Oresund, where there was already a substantial number.

Roskilde, og i de følgende år fik mange nonneklostre en prior udpeget af kongen. Disse forhold fortsatte under de næste konger specielt under Frederik I's regering i 1520'erne, hvor også munkeklostre fik indsat mandlige lensmænd, og hvor klostrene blev opfattet som kongelige len. Allerede fra begyndelsen af sin regeringstid brugte Frederik udtrykket "vort og kronens kloster". ${ }^{6}$

\section{Mecklenburg-Vorpommern og Hinterpommern ${ }^{7}$}

I Mecklenburg-Vorpommern var der 23 klostre i byerne og 24 i landområder. ${ }^{8}$ I landområderne var det væsentligst benediktiner - og cistercienserklostre med ganske få grundlagt i slutningen af 1100-tallet og med hovedparten fra første halvdel af 1200-tallet. Blandt landklostrene var der ikke færre end 12 nonneklostre. 9 
Efter 1400 blev der kun oprettet fem nye konventer i dette område (fig. 3). Lige uden for Stralsund lå birgittinerklostret Mariakron grundlagt i $1421 .{ }^{10} \mathrm{De}$ øvrige klostre blev oprettet i byerne.

Et specielt samfund "Brüder vom Gemeinsamen Leben" (Brødrene af Fælleslivet) kom til Rostock i $1480 .{ }^{11}$ Her havde de indrettet et vigtigt værksted i deres hus til trykning af bøger. Man kan dog godt diskutere, om samfundet bør opfattes som en rigtig klosterorden. Brødrene skulle ikke aflægge klosterløfte, Så i teorien kunne de forlade huset, når de ønskede det. De skulle leve af deres eget arbejde og ikke fra tiggeri, så de blev mødt med betydelig modstand fra tiggerordenerne. Huset fortsatte også i mange år efter Reformationen i Rostock, hvilket må ses som en væsentlig bekræftelse på deres status uden for klostervæsnet. Den ret specielle bygning med kapel i den ene ende og beboelse samt værksteder i den anden er fortsat bevaret (fig. 4). I Bützow oprettede den kvindelige modpart "Schwestern vom Gemeinsamen Leben" et hus i $1468 .{ }^{12}$

Franciskanernes kloster i Güstrow blev grundlagt meget sent i 1510 som et forsøg på at fremme franciskansk observans. ${ }^{13}$ I Sternberg blev et konvent for

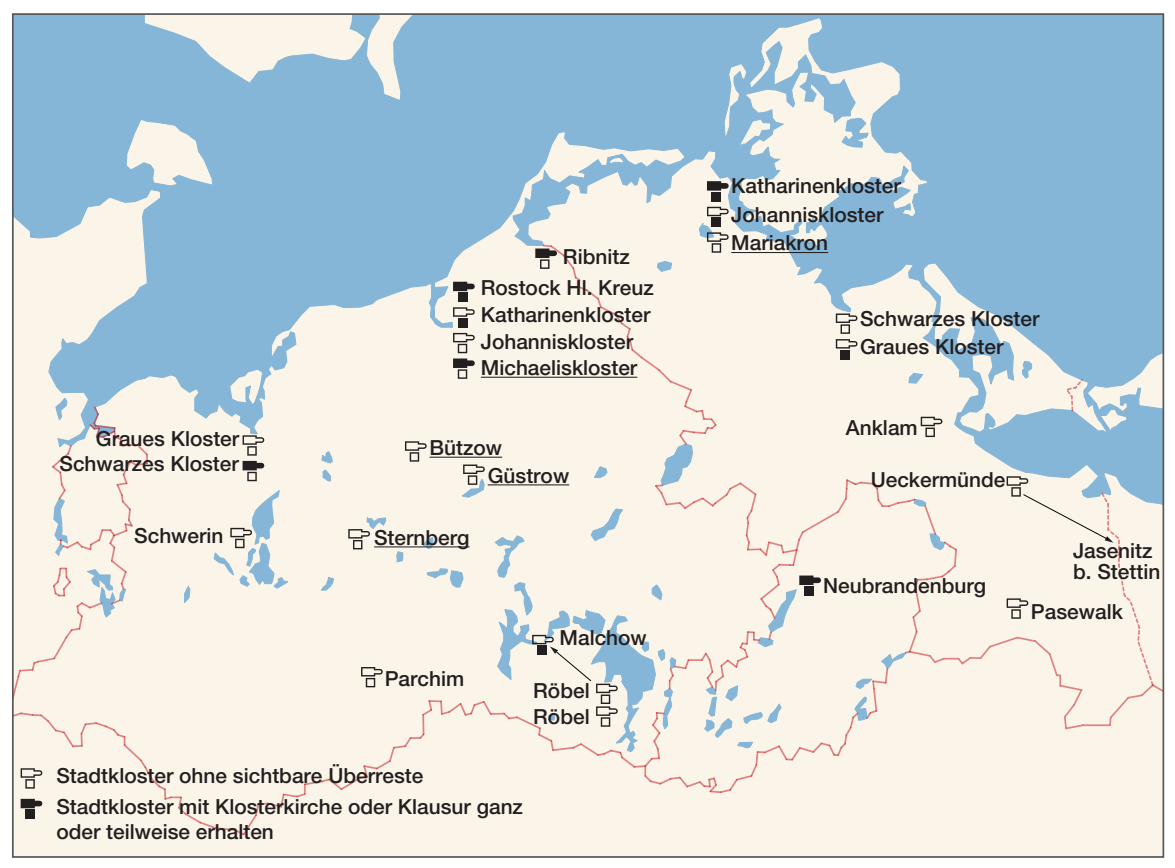

Fig. 3. Klostre i byerne i Mecklenburg-Vorpommern. Klostre stiftet efter 1400 er understreget. - Tegning: Martin Ebert, efter Ebert \& Grundner 2009.

Monasteries in the towns in Mecklenburg-Vorpommern. Those established after 1400 are underlined. 


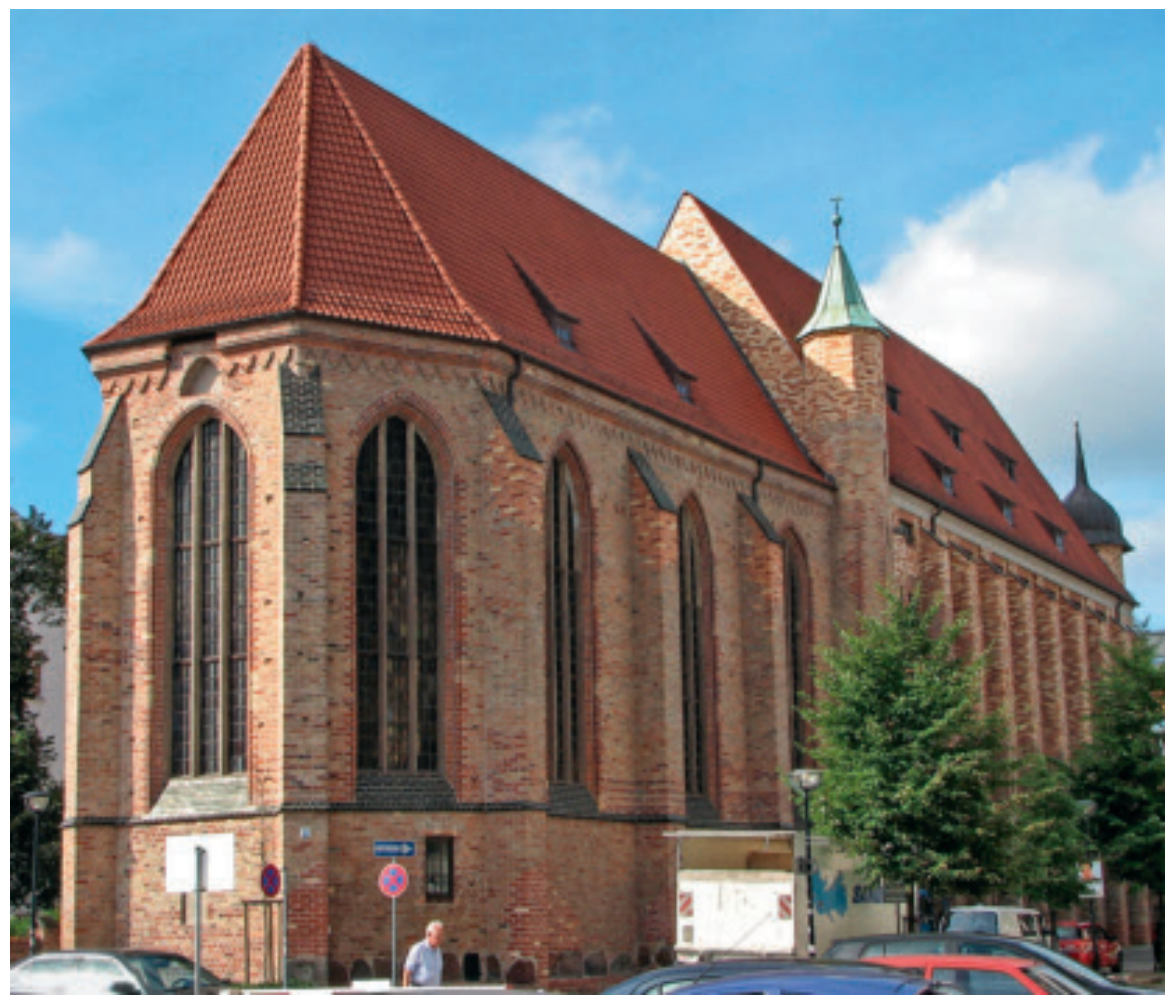

Fig. 4. Kirke (St. Michaelis) og bolig for Brødrene af Fælleslivet i Rostock. Bygningen blev opført i tiden efter 1480. Sammenbygget bag den gotiske kirke ligger der et hus i fire etager, hvor brødrene foruden bolig også havde et trykkeri og et bogbinderi. Bygningen blev genopført i 1950'erne efter et ødelæggende engelsk bombardement i 1942. - Foto: Darkone (Wikimedia) 2005.

Church (St. Michael's) and residence of the Brethren of the Common Life in Rostock. The building was constructed in the time after 1480. A four-storey building integrated into the back of the Gothic church is where the friars, in addition to their living quarters, had printing and book-binding workshops. The building was rebuilt in the 1950s following destruction by a British bombardment in 1942 .

Augustinereremitter - den fjerde tiggerorden - oprettet i 1504 for at tage vare på et pilgrimsmål. ${ }^{14}$ Augustinereremitterne fandtes ikke i Danmark i middelalderen, men var almindelige i Tyskland. Martin Luther tilhørte denne orden. I 1527 konverterede alle brødre i Sternberg i øvrigt til den lutheranske tro og lukkede deres kloster. Det var en ganske speciel begivenhed i Mecklenburg og Nordtyskland, da det var en meget tidlig lukning af et kloster.

Et kartheuserkloster blev stiftet i Hinterpommern tæet ved Rügenwalde i 1407 og et karmeliterkloster fra 1441 i Stettin. ${ }^{15}$ Sidstnævnte havde mange problemer med etableringen, og kirken blev aldrig bygget færdig. 
Sammenlignet med forholdene i Danmark var der ingen Helligåndsklostre i Mecklenburg-Vorpommern. Ansvaret for hospitalerne i Nordtyskland henhørte formentlig under de forskellige byers kommunale styre. Karmeliterne havde kun det ene konvent i Stettin i Hinterpommern. Brødrene af Fælleslivet kan let ses som en kritik af tiggerordenernes liv, og havde muligvis en negativ indflydelse på grundlæggelse af nye tiggerklostre i senmiddelalderen. Helt tydeligt var interessen $i$ at stifte nye klostre i senmiddelalderen betydeligt mindre i Mecklenburg og Pommern end i Danmark. I hele Mecklenburg og Pommern blev $10 \%$ af klostrene stiftet efter 1400 sammenlignet med $24 \%$ i Danmark.

\section{Byggeaktivitet i Danmark}

Vendende tilbage til de danske klostre var der naturligvis en vældig byggeaktivitet blandt de mange nyoprettede klostre. Mariager Kloster, der først fik pavelig godkendelse i 1446, var ved Reformationen utvivlsomt det største middelalderlige bygningskompleks i Jylland (fig. 5). ${ }^{16}$ Af andre store anlæg fra den sene middelalder kan nævnes karmeliterklostret i Helsingør og Aalborg Helligåndskloster. Byggeboomet ved klostrene omfattede dog ikke kun nyoprettede steder, men der var også stor aktivitet ved de gamle. Som eksempler på det sidste kunne man nævne vestfløjen i Vitskøl fra 1520'erne og korsgangen i Skovkloster dateret til 1502 (fig. 6). Tydelig er også udviklingen af Øm Kloster, hvor hovedparten af klosteranlægget bortset fra østfløjen og den ufuldførte kirke tilhørte 1400- og begyndelsen af 1500-tallet. Byggeboomet i senmiddelalderen for næsten alle danske klostre synes at have været et generelt fænomen (og måske også lidt specielt) for vort land. ${ }^{17}$ Bevægelsen var væsentlig, og hovedparten af de stadig eksisterende klosterbygninger i Danmark tilhører perioden efter 1400. Mange danske klostre opnåede først det traditionelle lukkede anlæg omkring en klostergård i slutningen af middelalderen.

\section{Byggeaktivitet i Mecklenburg-Vorpommern}

I 1400-tallet fik klosterkirken i Dargun opført et nyt kor og tværskib. ${ }^{18}$ Formentlig påbegyndt i første fjerdedel af århundredet tog det meget lang tid at afslutte det enorme projekt (fig. 7). Bygningsdelen var forberedt med stående fortandinger til en videreførelse med tilsvarende skib; men dette blev aldrig realiseret. I virkeligheden synes det store foretagende at være en undtagelse blandt klostrene i Mecklenburg-Vorpommern. Byggeriet var da også planlagt i en skala, som ikke kendes fra danske cistercienserklostre.

Naturligvis er meget gået tabt, og mange bygninger kan ikke dateres eksakt; men i betragtning af, hvad der stadig er bevaret, ses ingen større byggeprojekter andetsteds. I Krummin og Neubrandenburg var der mindre ombygninger af 


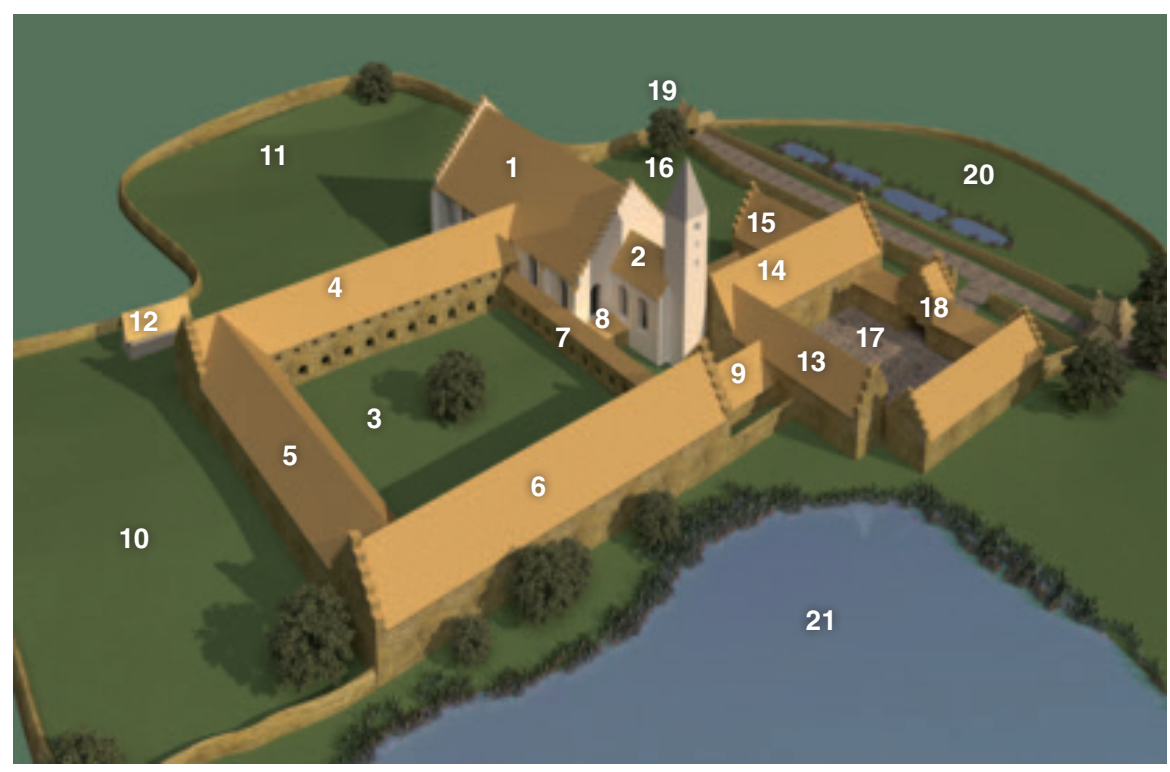

Fig. 5. Rekonstruktionstegning af hovedanlægget ved Mariager Kloster som det kan have set ud på reformationstiden. 1) Kirken. 2) Eksisterende brødrekor med tilmuret dør til skriftemålshuset i nord. 3) Søstrenes gård, der sikkert har været græsklædt, så den var egnet til tøjblegning. 4) Hovedbygning med søstrenes dormitorium. 5) Nordføø. 6) Vestfløj med køkken og formentlig bryggeri samt forrådsrum. 7) Korsgange omkring søstrenes gård. 8) Skriftemålshuset der var delt i to rum. 9) Taleporten. 10) Formentlig pladsen for klostrets ladegård. 11) Klostrets kirkegård. 12) Formentlig fattigasyl, Kierlingehuset. 13) Brødreklostrets eksisterende nordfløj. 14) Brødreklostrets hovedbygning hvorfra præstebrødrene har haft direkte adgang til deres kor i kirken gennem tårnets syddør. 15) Brødrenes kapitelsalsbygning. 16) Brødrenes have (en del af klausuren). 17) Brødrekonventets vestlige gård. 18) Sydfløjen. 19) Porthus fra lensmandstiden. 20) Klosterhave med fiskedamme. 21) Den kunstigt anlagte klosterdam. - Tegning: Tais Koopmann 2013.

Reconstruction of the main complex at Mariager abbey as it could have appeared at the time of the Reformation. 1) Church. 2) Existing friars' choir/chancel with walled-up door to the confession house in the north. 3) The sisters' yard, which was probably grasscovered so it was suited to bleaching clothes. 4) Main building with the sisters' dormitory. 5) North wing. 6) West wing containing a kitchen and probably a brewery, as well as a pantry. 7) Cloisters around the sisters' yard. 8) The confession house which was divided into two rooms. 9) Speaking gate. 10) Probably the site of the abbey's farm buildings. 11) The abbey's churchyard. 12) Probably poorhouse, Kierlingehuset. 13) The existing north wing of the brethren. 14) The brethren's existing north wing from where the priests had direct access to their choir/chancel in the church through the southern door of the tower. 15) The brethren's chapter house. 16) The brethren's garden (part of the enclosure). 17) The brethrens western yard. 18) South wing. 19) Gatehouse from the vassal period. 20) Abbey garden with fishponds. 21) The artificially made abbey pond. 
korpartierne. ${ }^{19}$ Konventet i Tempzin byggede et nyt fritstående hus, og dominikanerne i Stralsund fik en stor sal i 1400-tallet. ${ }^{20}$ Cisterciensernonnerne i Hellig Kors Kloster i Rostock overhvælvede deres refektorium i $1480 .{ }^{21}$ Dette kan på ingen måde sammenlignes med den store aktivitet i Danmark. Hvad angår de fysiske forhold, var klostervæsnet i Danmark i en langt bedre form end i Mecklenburg-Vorpommern. På forskellig måde var interessen for klostre betydelig mere afdæmpet i sidstnævnte område end i Danmark.

\section{Reformationens begyndelse}

\section{De danske tiggerklostres skæbne}

Lukningen af de danske tiggerklostre begyndte adskillige år før, den endelige beslutning til en fundamental reform af kirken blev taget i 1536. I årene 1528 til 1532 forsvandt 19 ud af 26 af de franciskanske klostre, som det kan følges i Krøniken om gråbrødrenes fordrivelse (De expulsione fratrum minorum) (fig. 8). ${ }^{22} \mathrm{Vi}$ kender ikke alle detaljer om udviklingen for dominikanerne, men

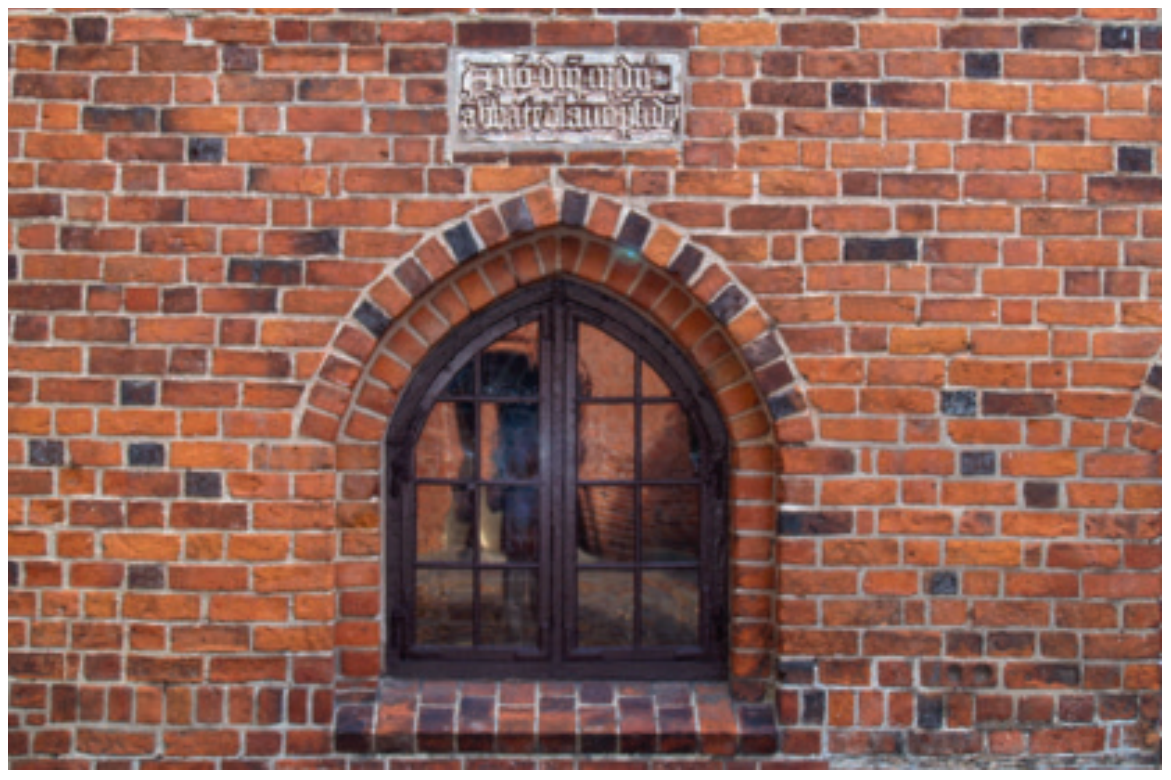

Fig. 6. Indskriftstavle på korsgangen i Skovkloster. Denne del af korsgangen blev opført under ledelse af abbed Oluf i 1502. "An[n]o D[omi]ni MDII abate olauo p[re]side[nte]". Den grundmurede korsgang har utvivlsomt erstattet en ældre opført i træ eller bindingsværk. - Foto: HKK 2011.

Inscription plate on the cloister at Skovkloster. This part of the cloister was built under the direction of Abbot Oluf in 1502: "An[n]o D[omi]ni MDII abate olauo p[re]side[nte]". The brick-built cloister undoubtedly replaced an earlier timber or half-timbered structure. 


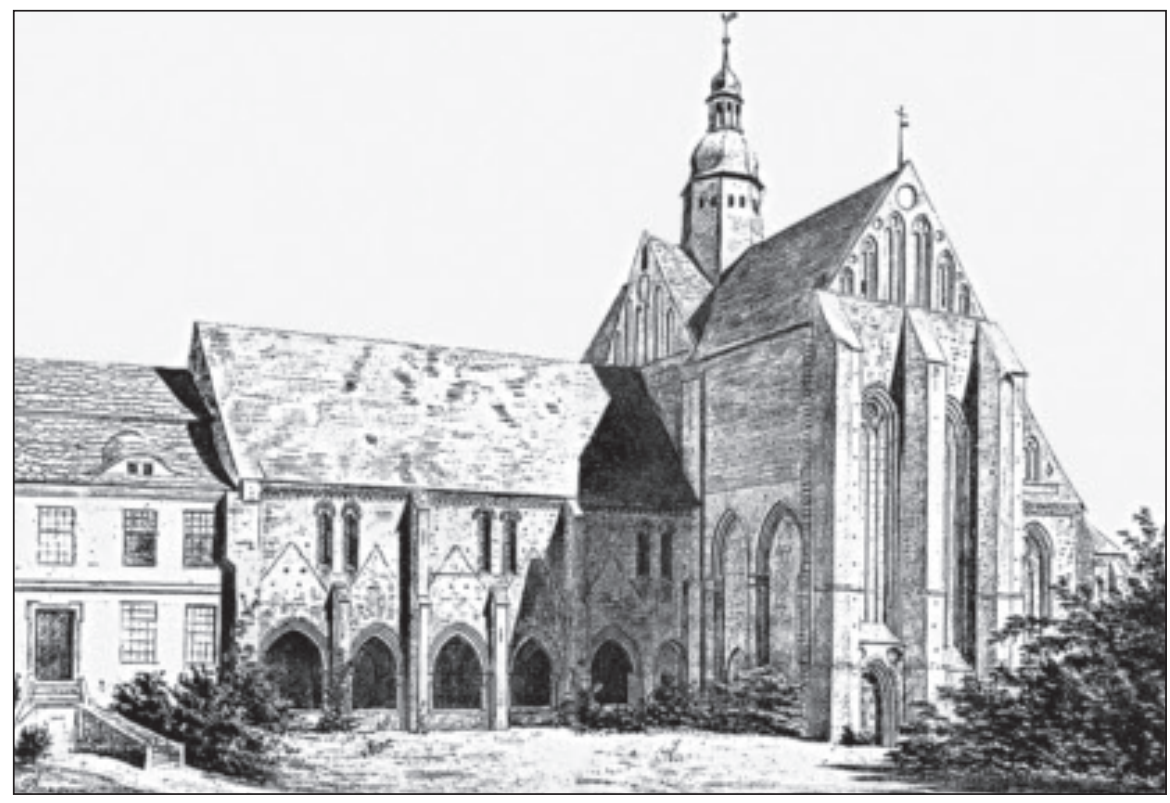

Fig. 7. Cistercienserkirken i Dargun set fra sydvest. Hovedskibet (med manglende sideskib) er fra første halvdel af 1200-tallet og i dansk cistercienserstil. Det nye kor og tværskibet blev færdiggjort i tiden 1464-79. Tværskibet blev opført med en meget høj bue mod skibet og der afsluttet med fortandinger på korsarmens sydvesthjørne til et kolossalt skib, som aldrig blev opført. - Tegning: Jacob Kornerup 1875, efter Kornerup 1881.

The Cistercian church in Dargun, seen from the southwest. The nave (with missing side aisle) is from the first half of the 13th century and built in Danish Cistercian style. The new choir/chancel and the transept were completed in the period 1464-79. The transept was constructed with a very high vault towards the nave and terminated there with toothing on the transept's southwest corner for the attachment of an enormous nave that was never constructed.

deres situation var nok af samme art. For karmeliternes vedkommende blev brødrene i Assens, hvor karmeliterbroder Peder Laurentsen havde prædiket evangelisk siden 1527, fordrevet i 1529. I København forlod de kollegiehuset i 1530, og samme år overlod brødrene i Landskrona deres kloster til byen. ${ }^{23}$

Det er helt klart, at ophævelserne var accepteret og tilskyndet af kong Frederik I. I mange tilfælde ses det, at klosterbygningerne blev lovet til byens borgere på forhånd som et hospital, et rådhus eller en skole i tilfælde af, at brødrene forlod deres huse. Derfor hjalp borgerne i mange byer på forskellig vis med at drive franciskanerbrødrene ud. Således skete det i Horsens, hvor borgerne ikke kunne afvente en frivillig afrejse, men drev dem ud på en umenneskelig måde. ${ }^{24}$ I Svendborg har vi dog et specielt tilfælde: Både i 1530 og igen i 1532 blev borgmestre og råd tilbudt kirken og klosterbygningerne som hospital, 


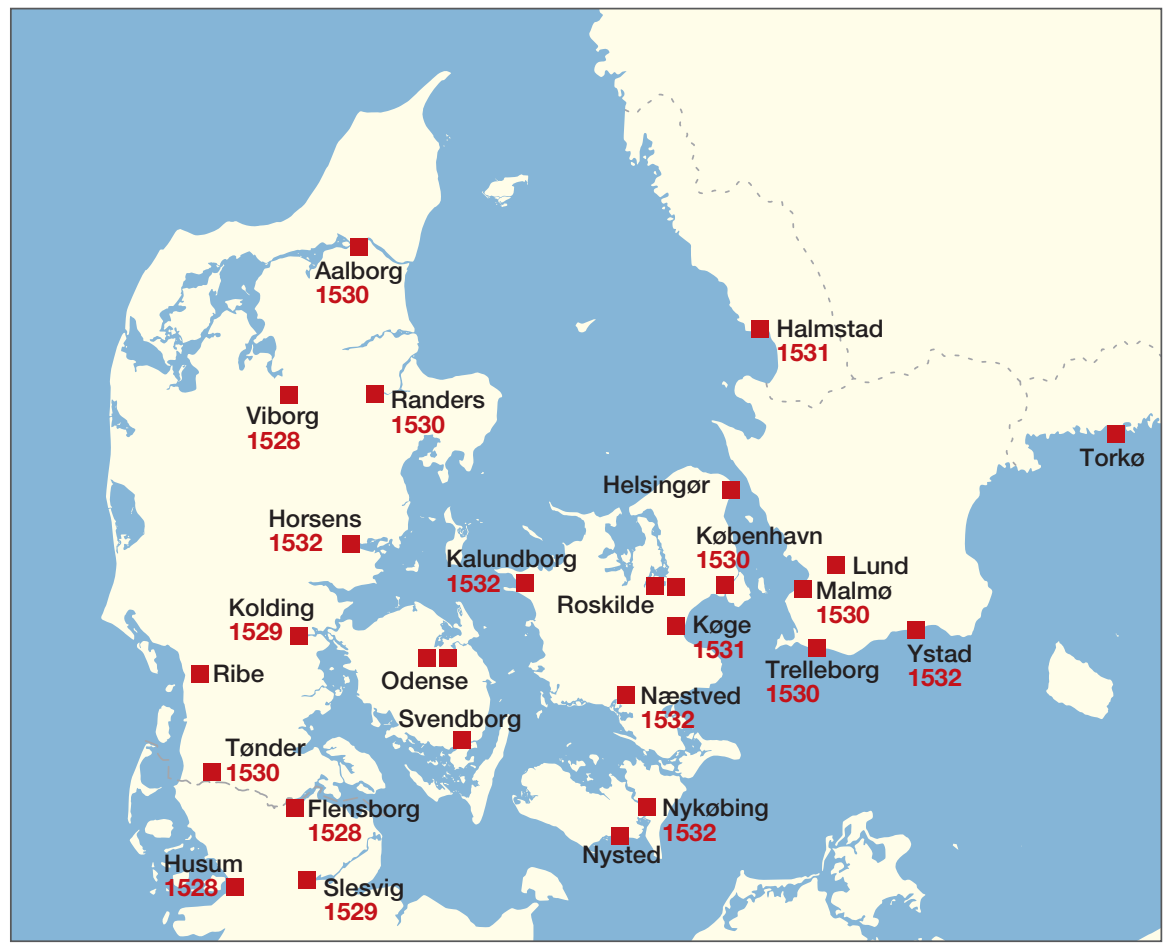

Fig. 8. Kort over danske franciskanerklostre med årstal for deres nedlæggelse. Nedlæggelserne har været spredt over hele landet, men det er karakteristisk, at nogle af stiftsbyerne som Ribe, Odense, Roskilde og Lund med et stærkt katolsk islæt ikke blev berørt i den tidlige fase af klosternedlæggelser.

Map of the Danish Franciscan monasteries with the year of their dissolution. The dissolutions took place across the entire country, but it is characteristic that some of the cathedral cities such as Ribe, Odense, Roskilde and Lund, with a strong Catholic element, were not affected in the early phase.

så snart franciskanerne havde forladt bygningerne. ${ }^{25}$ Borgerne tøvede dog, og brødrene blev ikke fordrevet. Formentlig fungerede klostret videre indtil opløsningen af tiggerordenerne ved Kirkeordinansen af 1537. Franciskanerkonventet i Nysted blev lukket som det sidste i 1538.

Det er ganske interessant, at kongen tidligt påberåbte sig retten til at disponere over tiggerklostrenes bygninger. Det er der dog også en vis logik i. Efter overgangen til observansen havde franciskanerne fuldstændig afsagt sig ejerskab og overladt denne til paven. Samtidig havde den danske kirke i 1526 brudt forbindelsen til pavestolen. For at undgå at bygninger og inventar skulle gå tilbage til de oprindelige givere, opførte kongen sig som om, at han var den virkelige ejer af bygningerne. Så længe brødrene forblev i klostret, havde de 
ret til af bruge bygningerne; men i det øjeblik, de forlod dem, havde kongen ret til at disponere, som han lystede.

Selv om mange klostre i princippet blev overladt til købstæderne, kunne disse ofte ikke finde anvendelse for bygningskomplekserne. Efter få årtier var hen ved 40 byklostres kirker forsvundet. Og hvor kirkerne blev bevaret, forsvandt de øvrige bygninger hurtigt.

\section{Den tidlige Reformation i Pommern}

De lutherske ideer blev forst introduceret i Pommern i præmonstratenserklostret Belbuck nær Treptow (fig. 9). ${ }^{26}$ I 1504 havde abbeden indstillet Johannes Bugenhagen som leder af byskolen i Treptow. ${ }^{27}$ Han blev ansat og gjorde skolen berømt i Nordtyskland, og i 1517 blev han også lektor i Belbuck. I slutningen af året 1520 blev Bugenhagen introduceret til Luthers skrift: De capitivitate Babylonica ecclesiae praeludium (om kirkens babyloniske tilfangetagelse). I løbet af kort tid blev han og en stor del af indbyggerne i Treptow tilhængere af Luther. I 1521 forlod korherrerne klostret, og deres ideer blev spredt over hele Pommern som fx til Stralsund. Belbucks besiddelser blev overtaget af hertug

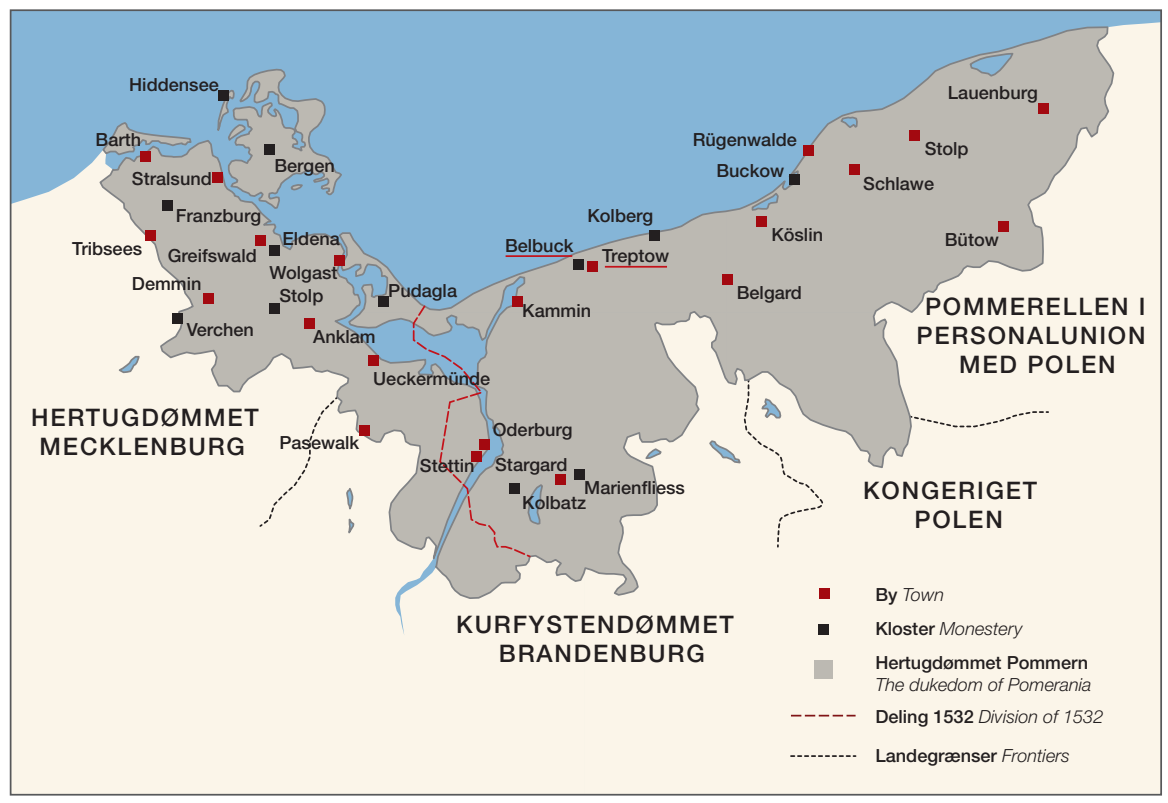

Fig. 9. Hertugdømmet Pommern på reformationstiden med angivelse af byer og klostre. Klostret Belbuck og byen Treptow er understreget. - Efter Leder \& Buske 1985, rentegning: Morten Larsen 2019.

The Duchy of Pomerania at the time of the Reformation showing towns and monasteries. Belbuck monastery and the town of Treptow are underlined. 
Bogislaw X (1474-1523). ${ }^{28}$ Han var i øvrigt svigerfar til Frederik, hertug af Slesvig-Holsten og senere konge af Danmark, og han var ikke protestant. Bygningerne i Belbuck forsvandt i øvrigt meget hurtigt.

Elever fra Treptow og kanniker fra Belbuck spredte de evangeliske tanker til andre steder i Nordtyskland efter lukningen. Andreas Knopke (en kollega til Bugenhagen i Treptow) rejste til Riga og blev af byrådet kaldet til prædikant i byen i 1522. Christian Ketelhut (en munk fra Belbuck) kom til Stolp (i Bagpommern) i 1521, men forlod byen efter nogle problemer med greven der og kom i stedet til Stralsund i 1523. ${ }^{29}$ Abbeden fra Belbuck, Johan Boldewan, tog studier i Wittenberg efter klostrets lukning og rejste senere til Hamburg. ${ }^{30}$

Næsten på samme tid, som Bugenhagen arbejdede i Treptow, begyndte en franciskaner, Johannes Knipstro, i 1521 at prædike evangelisk i franciskanerklostret i Pyritz. ${ }^{31}$ Efter trusler fra det nærliggende cistercienserabbedi i Kolbatz rejste han til Stettin i 1522/23 og senere til Stralsund i 1525.

Ligeledes begyndte augustinereremitterne i Anklam at forlade klostret, og det blev endeligt lukket i $1530 .^{32}$

\section{Den tidlige Reformation i Stralsund}

Byen Stralsund var en delvis uafhængig by i hertugdømmet Pommern, og byrådet ønskede helt afgjort at få de samme forhold som i Lübeck, hvilket var "Reichsunmittelbar", der betyder direkte under riget uden nogen regerende fyrste mellem by og kejser.

Lukningen af tiggerklostrene i Nordtyskland begyndte i Stralsund i 1525. En vis uro i byen både social og religiøs med prædikener af reformatoren Christian Ketelhut gennem er par år kulminerede i en kirkestorm, kaldet “das Kirchenbrechen", den 10. april 1525. Bystyret havde kaldt de fattige indbyggere sammen til et møde i Sankt Nikolai Kirke, men mødet endte i optøjer. Kirkens indre blev raseret, og senere angreb mængden franciskanernes kirke og kloster, ødelagde altrene og drev brødrene $u d .{ }^{33}$ Dernæst fulgte birgittinerklostret uden for murene, hvor al inventar blev smadret og mange bygninger ødelagt. Herefter blev der øvet hærværk i nogle af de andre kirker. ${ }^{34}$ Bystyret ønskede utvivlsomt at straffe de skyldige, men aktionen endte i de følgende dage med en ændring af byrådet og en officiel indførelse af protestantismen på den lutherske måde i byen Stralsund som det første sted i Nordtyskland. De to tiggerklostre blev lukket og genbrugt af byen. ${ }^{35}$ Franciskanernes kloster blev omdannet til et hospital for syge og fattige, mens dominikanernes med tiden blev til en skole.

Dominikanerne var kommet til Stralsund i 1251 og fik en grund i den vestlige del af byens "altstadt" ud mod bymuren. Ganske hurtigt fik de opført 
det største tiggerkloster i Nordtyskland (fig. 10). Tagværket over kirken er velbevaret, og takket være dendrokronologiske dateringer har man kunnet følge det ret hurtige byggeri fra slutningen af 1200 -tallet. ${ }^{36}$ Den hastige byggegang ved den store treskibede kirke vidner om hansestadens store økonomiske betydning i slutningen af 1200-tallet. Dominikanerkirken fungerer i dag som det tyske Havmuseum og er desværre delt i to etager med et indskudt gulv. Ellers er der tale om det bedst bevarede tiggerkloster i Nordtyskland - måske i hele Tyskland.

Franciskanerklostret blev grundlagt i 1254 og fik en grund yderst mod nord i byen ud mod Strelasund, hvor man formentlig ganske hurtigt opførte en kirke med et tredelt skib og et smallere kor. I slutningen af 1200-tallet blev østfløjen forlænget op mod bymuren, og der blev opført en nordfløj langs muren. (fig. 11). Skibet i franciskanerkirken brændte i 1624, og koret blev bombet i 1944. Kirken udgør i dag en stemningsfuld ruin. Trods kirkens ødelæggelse har vi

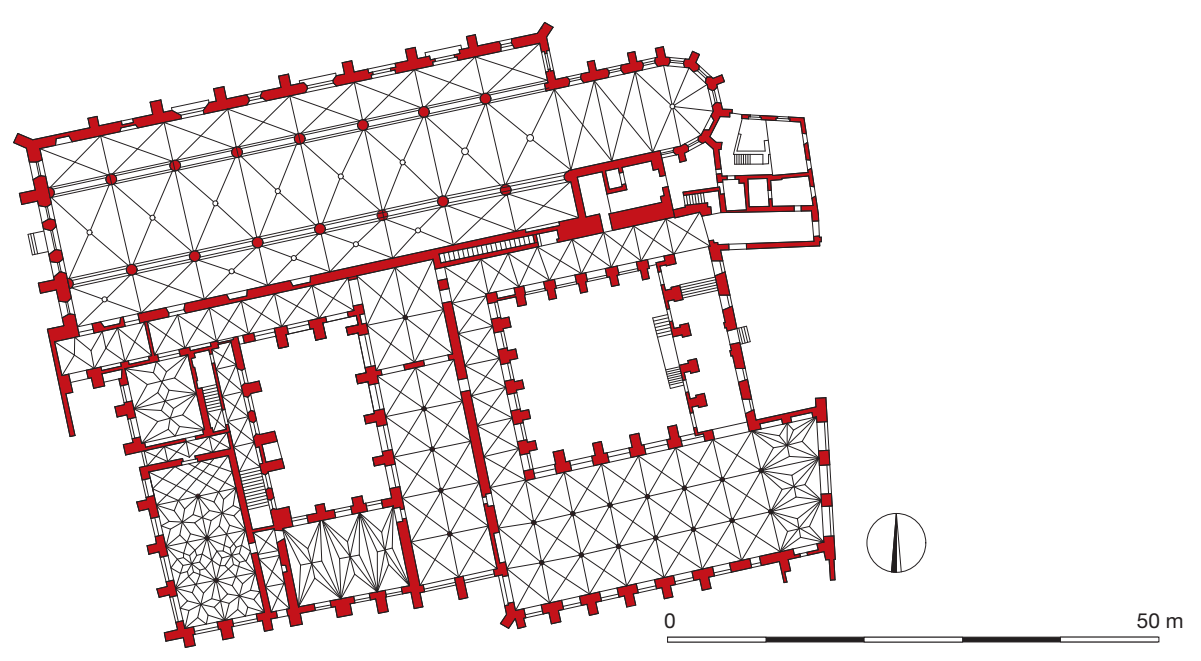

Fig. 10. Grundplan af dominikanerklostret i Stralsund. Koret blev opført i 1282, mens skibet dateres til 1292 og 1308. Klosterbygningerne repræsenterer mange byggefaser fra 1200 -tallet til o. 1500. Den store treskibede sal i sydøst fra tiden o. 1420 opfattes som klostrets sommerrefektorium, Remter. De to klostergårde med korsgange skal muligvis ses i problematikken omkring offentlige og lukkede fratergårde. - Tegning: Martin Ebert, efter Ebert \& Grundner 2009.

Ground plan of the Dominican friary at Stralsund. The chancel was built in 1282, while the nave is dated to 1292 and 1308 . The friary buildings represent numerous construction phases from the 13th century to around 1500 . The large three-aisled hall in the southeast from around 1420 is perceived to be the friary's summer refectory, Remter. The two cloister garths with cloisters should possibly be understood in the light of the matter of public and private (enclosed) friar's yards. 




Fig. 11. Grundplan af franciskanerklostret i Stralsund. Kirken blev påbegyndt i anden halvdel af 1200-tallet, og det centrale klosteranlæg regnes for færdiggjort i begyndelsen af 1300-tallet. Også her kom der senere en ekstra klostergård længere væk fra kirken. De to gårde er tolket som henholdsvis en offentlig og en privat gård. - Tegning: Martin Ebert, efter Ebert \& Grundner 2009.

Ground plan of the Franciscan friary at Stralsund. The building work on the church began in the second half of the 13th century, and the central complex is thought to have been completed in the early 14th century. Here too, a second cloister garth was added later, further away from the church. The two yards are interpreted as, respectively, a public and a private yard.

to velbevarede eller i det mindste velkendte klosteranlæg i Stralsund. De har begge haft store kirker og mere eller mindre dobbelte klosteranlæg.

Som hovedparten af de nordtyske tiggerklostres kirker er/var kirkerne i Stralsund treskibede med et enskibet kor. I modsætning hertil var hovedparten af de danske franciskaner- og dominikanerkirker enskibede salskirker eller asymmetrisk toskibede. Den treskibede version finder vi kun ved de alleryngste kirker som dominikanernes Sankt Catharinæ i Ribe, karmeliternes klosterkirke i Helsingør og de tre helligåndskirker i Randers, Fåborg og København.

Birgittinersøstrene fra klostret Mariakron uden for byen Stralsund blev genhuset i det tomme dominikanerkloster. De forblev katolikker. Nye novicer blev ikke tilladt, og den sidste søster døde i 1559. ${ }^{37}$ Efter en kort anvendelse af 
de resterende bygninger i klostret Mariakron til hjemløse, begyndte man at rive bygningerne ned for at genbruge byggematerialerne. ${ }^{38}$ Udformningen af klosteranlægget er helt ukendt.

Den nye tro i Stralsund forårsagede problemer for naboområderne som eksempelvis i 1528, hvor en skare fra Stralsund lavede et iconoclastisk raid til cistercienserabbediet på øen Hiddensee vest for Rügen og ødelagde en masse altertavler i kirken.

Reformationen i Stralsund bredte sig til andre byer i regionen herunder Malmø i Skåne, og mange tiggerklostre blev lukket i de følgende år i Pommern. Det skete ikke systematisk som i Danmark, og lukningerne blev ikke støttet af hertugerne.

\section{Reformationen i Pommern}

Ligesom Danmark havde Det Tyske Rige eller det kejserlige imperium som sådan klare grænser og kun én regent. Derimod var det helt anderledes i mange små og større fyrstendømmer, som udgjorde Det Tyske Rige, og hvor den væsentligste del af magten fandtes i senmiddelalderen. I fyrstendømmerne har vi mange eksempler på, at to brødre arvede magten, eller at en del af fyrstedømmet blev givet væk som medgift. Regentskabet med to regenter kunne organiseres på forskellig måde. De to fyrster kunne regere i fællesskab, hertugdømmet kunne være delvis delt med nogle elementer som fælles områder, eller helt delt i to fyrstendømmer. Senere kunne de to dele eksempelvis ved arv samles igen.

I de sene 1520'ere blev Pommern styret i fællesskab af de to brødre, Georg I og Barnim XI, sønner af Bogislaw X. I denne periode begyndte den lutheranske bevægelse i byerne, som vi har set det i Stralsund, og fortsatte mange andre steder med en mængde uro i hertugdømmet. ${ }^{39}$ I 1531 døde Georg og blev efterfulgt af sin søn Philipp, og i 1532 delte han og Barnim landet i to: Pommern Wolgast og Pommern Stettin, nogenlunde som i dag langs grænsen mellem Tyskland og Polen. For at løse problemet om de kirkelige forhold indkaldte de til et møde, et såkaldt "Landtag" i Treptow an der Rega i 1534. ${ }^{40}$ På dette tidspunkt støttede byen Stralsund sammen med nabobyen Lübeck Christian II's side i Grevens Fejde, mens hertugerne af Pommern støttede den anden side med Christian III. Så Pommern var ved at bryde sammen både politisk og religiøst. Mødet kan således ses som et forsøg fra hertugernes side på i det mindste at tage føringen i den reformatoriske bevægelse.

Ved mødet i Treptow deltog dr. Johannes Bugenhagen. Han var født i Wolgast i Pommern og havde som tidligere nævnt været leder af latinskolen i Treptow og lektor i Belbuck. ${ }^{41}$ Han arbejdede nu sammen med Martin Luther 
i Wittenberg. Han var blevet en ekspert i skabelsen af nye protestantiske kirker, hvilket han havde gjort i Braunschweig 1528, Hamburg 1529 og Lübeck 1530. Senere skabte han kirkeordinansen for den danske kirke i 1537.

Ved mødet ønskede hertugerne at gennemføre en reformation i hele Pommern. Da dette også inkluderede hertugernes overtagelse af de jordejende klostre, forlod adelen dog mødet i protest. ${ }^{42}$ Alligevel blev resultatet, at Bugenhagen skrev den nye konstitution for kirken, som blev trykt i 1535, og mandsklostrene og de tilbageværende tiggerklostre blev lukket.

De fleste nonneklostre blev dog holdt åbne for nye novicer for at tilfredsstille adelen, og lidt senere omkring 1560 blev nogle af disse klostre omdannet til lutherske konventer for adelige kvinder, som det kendes i Bergen, Kolberg, Marienfließ, præmonstratenserklostret i byen Stolp og det kortlivede Verchen. ${ }^{43}$ I det mindste Bergen, Marienfließ og Stolp fortsatte som sådan til 1945 (fig. 12). Kirken i Bergen er bevaret, mens Kolberg brændte i 1670 og blev efterfølgende

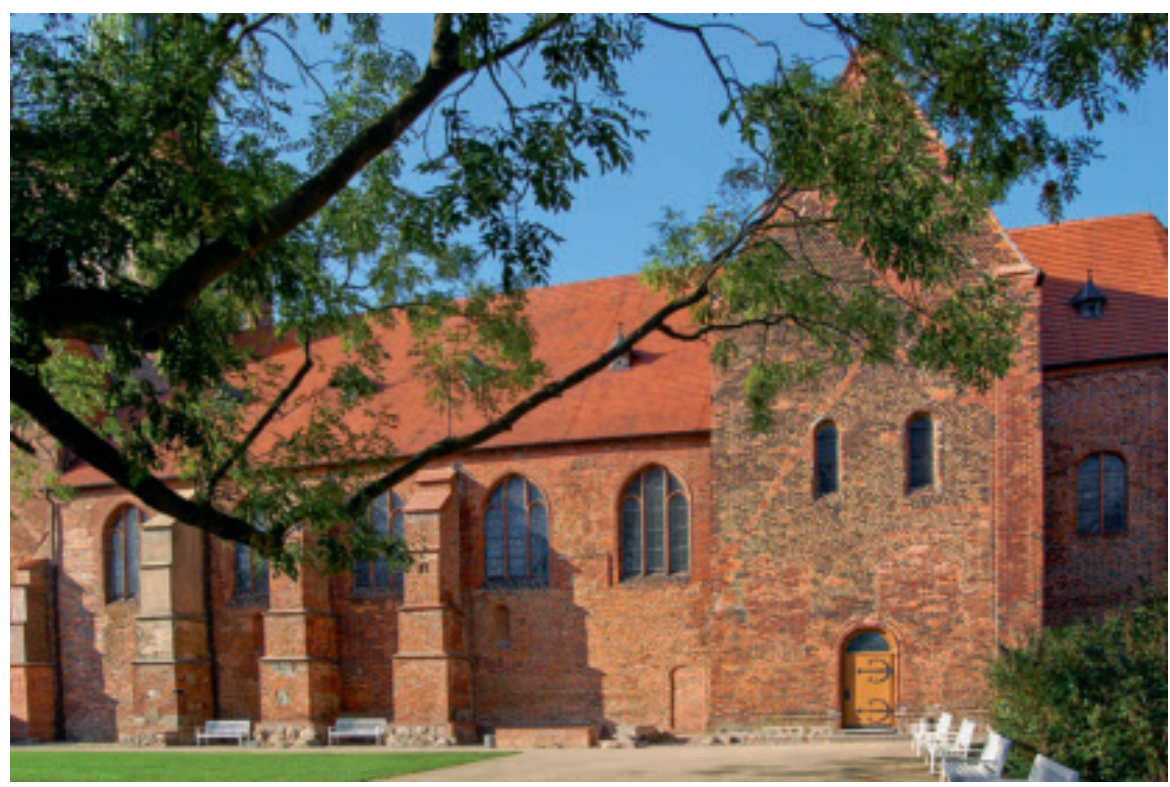

Fig. 12. Klosterkirken i Bergen set fra syd. Den færdige teglstenskirke blev i 1193 skænket af fyrst Jaromar af Rügen til nonner fra Vor Frue Kloster i Roskilde. De østlige dele af kirken (kor og tværskib) er tydeligvis opført i Den Sjællandske Teglstenstil. Skibet blev ombygget til hallekirke i senmiddelalderen. - Foto: Gerhard Giebener, Wikimedia Commons 2008.

The convent church in Bergen, seen from the south. In 1193, the completed brick-built church was given by Prince Jaromar of Rügen to nuns of Our Lady's abbey in Roskilde. The eastern parts of the church (chancel and transept) are clearly constructed in the Zealand brick style. The nave was converted into a hall church in the Late Middle Ages. 
nybygget. Marienfließ blev ødelagt af svenskerne under Trediveårskrigen og har i dag kun få middelalderlige spor. Stolp er efter ødelæggelse ombygget til skole.

Det meste af godset fra klostrene endte hos hertugerne, og som nævnt tidligere havde allerede den katolske hertug Bogislav X i 1532 lukket klostret i Belbuck og overtaget det tilhørende gods. Sandsynligvis var dette den første sekularisering af et herrekloster i hele Tyskland i reformationsårene. ${ }^{44}$

De stadigt eksisterende tiggerklostre blev lukket efter den endelige Reformation (fig. 13). Franciskanerne i Greifswald fik dog tilladelse til at blive i deres kloster i resten af deres liv, så først i 1556 blev bygningerne overladt til byen og genbrugt som en skole og et hospital. Kun en enkelt bygning fra klostret har overlevet nedrivninger i 1700-tallet og indgår i dag i det Pommersche Landesmuseum. I de mindre byer blev tiggerklostrenes bygninger revet ned. ${ }^{45}$ Eftersom de fleste mandlige klostre i Pommern blev lukket hurtigt i 1535, var munkene nødt til at forlade deres klostre, og godset blev omdannet til administrative enheder kaldt "amter" ${ }^{46}$ Fra da af havde klostrene hovedsageligt individuelle historier.

Som eksempler kan vi se på de store cistercienserabbedier i Eldena, Kolbatz og Neuenkamp. Generelt for disse gælder det, at de alle var betydeligt større end de danske cistercienserklostre, og efter alt at dømme også ejede større godskomplekser. Bygningerne i Eldena synes at have været nogenlunde intakte som en herregård frem til Trediveårskrigen, hvor de blev mere eller mindre

\author{
Vorpommern Vorpommern \\ 1525 Stralsund: franciskanere franciscans \\ 1525 Stralsund: dominikanere dominicans \\ 1530 Anklam: augustinereremitter austin friars (nedrevet demolished) \\ 1532 Pasewalk: dominikanere dominicans (nedrevet demolished) \\ 1531 Greifswald: dominikanere dominicans (universitet university) \\ 1534 Reformationen i Pommern Reformation Pomerania \\ 1535 Gartz: augustinereremitter austin friars (nedrevet demolished) \\ 1536 Greifswald: franciskanere franciscans (skole \& hospital school \& hospital)
}

\title{
Hinterpommern Hinterpommern
}

\begin{tabular}{|c|c|c|}
\hline 1525 & Stettin: franciskanere franciscans & (hospital hospital) \\
\hline 1525 & Stettin: karmelitere carmelites & (skole school) \\
\hline 1525 & Stolp: dominikanere dominicans & (nedrevet demolished) \\
\hline 53 & Reformationen i Pomme & Pomerania \\
\hline & Pyritz: franciskanere franciscans & (nedrevet demolished) \\
\hline & Greifenberg: franciskanere franciscans & (nedrevet demolished) \\
\hline & Stargard: augustinereremitter austin friars & s (skole school) \\
\hline
\end{tabular}

Fig. 13. Oversigt over lukningen af tiggerklostre i de to dele af hertugdømmet Pommern med angivelse af den efterfølgende brug.

Overview of the closing of mendicant friaries in the two parts of the Duchy of Pomerania, showing their subsequent use. 


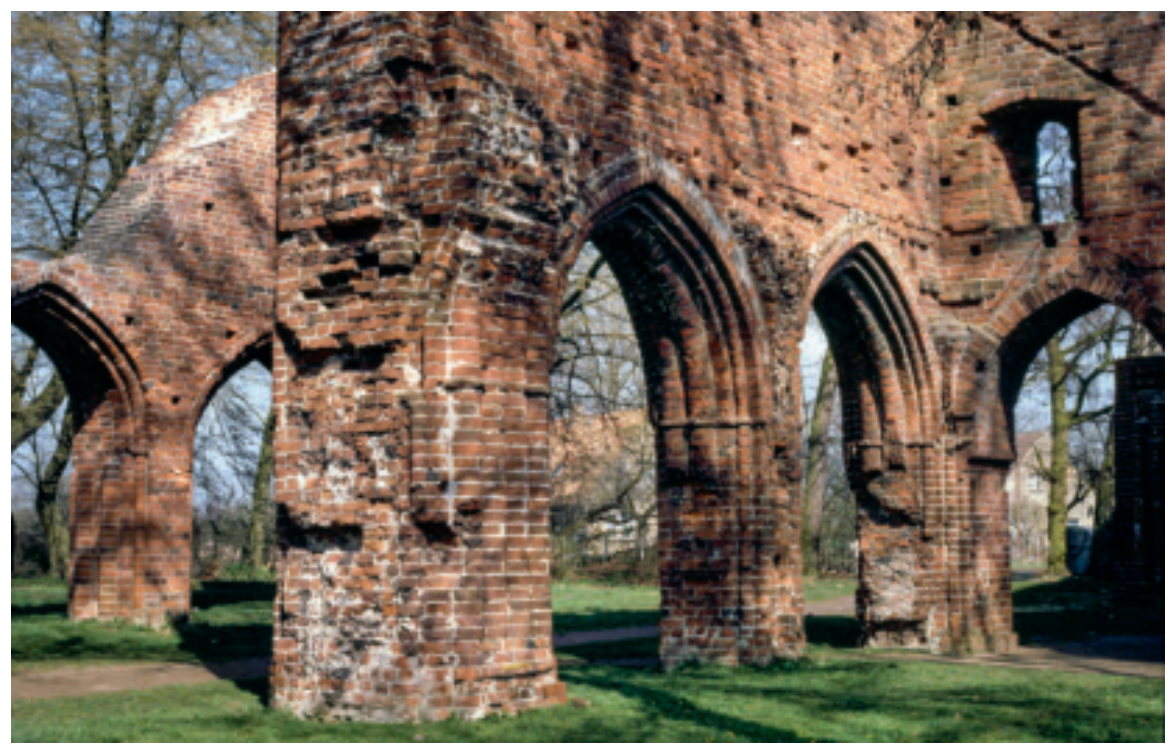

Fig. 14. Ruinerne af klosterkirken i Eldena. Et kik fra søndre sideskib mod korsskæringen. Klostret blev grundlagt i 1199 af munke, der var flygtet fra Dargun ud til kysten. Klostret var et datterkloster under Esrum, så kirkens østligste dele hører til den danske cistercienserstil. - Foto: HKK 1993.

The ruins of the abbey church at Eldena. A view from the southern side aisle towards the intersection of nave and transept. The abbey was founded in 1199 by monks who had fled out to the coast from Dargun. The abbey was a daughter house of Esrum, so the eastern part of the church belongs to the Danish Cistercian style.

ødelagte, hvorefter godset blev overført til universitetet i Greifswald. ${ }^{47}$ Ruinerne blev beskyttet som sådan fra omkring 1830 og udgør en meget malerisk ruingruppe (fig. 14).

Kirken i Kolbatz blev reduceret efter en brand i 1682 og skibet omdannet til en lade, men godset forblev intakt i hertugdømmet og senere i Preussen til begyndelsen af 1800-tallet, hvor det i en kort periode var privatiseret (fig. 15). Det er stadig i vore dage en meget stor landbrugsbedrift og en landbrugsskole (fig. 16). ${ }^{48}$

Klosterbygningerne til det godsrige cistercienserkloster Neuenkamp blev fra slutningen af 1530'erne benyttet som hertugelig residens. ${ }^{49}$ I $1561 \mathrm{blev}$ det meste af den enorme kirke revet ned, og kun den sydlige korsarm bevaret og ombygget til et protestantisk slotskapel (fig. 17). Selv i sin reducerede størrelse kan kirkebygningen virke imponerende. Omkring 1580 blev klosterbygningerne genopført og fik navnet Franzburg. Bortset fra kapellet blev resten dog fjernet i 1800-tallet og klostertomten benyttet som byggegrunde. 


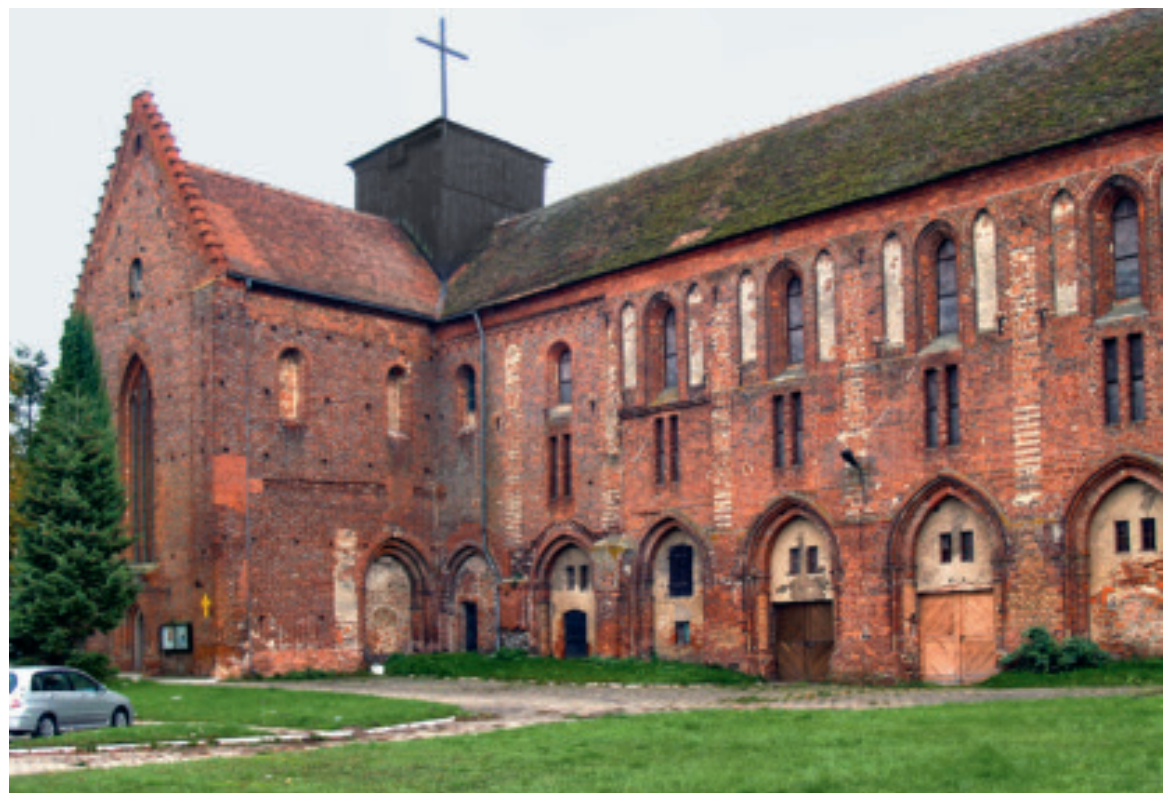

Fig. 15. Klosterkirken i Kolbatz set fra nordvest. Klostret blev grundlagt 1174 som et datterkloster af det danske kloster i Esrum. Tværskibet og de to østligste fag af skibet er fra den romanske periode med tydelige danske træk. Sideskibene blev nedrevet i 1700-tallet, hvor midterskibet blev ombygget til kornmagasin. - Foto: HKK 2006.

The abbey church in Kolbatz, seen from the northwest. The abbey was founded in 1174 as a daughter house of the Danish Esrum abbey. The transept and the two easternmost bays of the nave are from the Romanesque period with obvious Danish features. The side aisles were demolished in the 18th century, when the nave was converted into a granary.

\section{Den tidlige Reformation i Mecklenburg}

I første halvdel af 1500-tallet var der en ret speciel regeringsform i Mecklenburg med to regerende hertuger og hertugdømmet delt i tre dele. Der var to adskilte dele, som blev regeret af hver sin hertug (i Schwerin og Güstrow) og en yderligere del, som inkluderede de 12 største byer, prælaterne og klostrene, adelen og universitetet i Rostock, som blev regeret i fællesskab. ${ }^{50}$ Hertugdømmet var blevet delt i 1503 mellem to brødre. Den ene, hertug Heinrich V, var en proprotestantisk regent, mens den anden, Albrecht VII, var en overbevist katolik. Det gav en ganske uklar situation. Institutionerne blev opretholdt, men den protestantiske overbevisning blev prædiket og tolereret mange steder, men ikke overalt. Albrecht var engageret i Grevens Fejde i Danmark på Christian II's side. Efter nederlaget her mistede han derfor meget af sin indflydelse tilbage i Mecklenburg. 


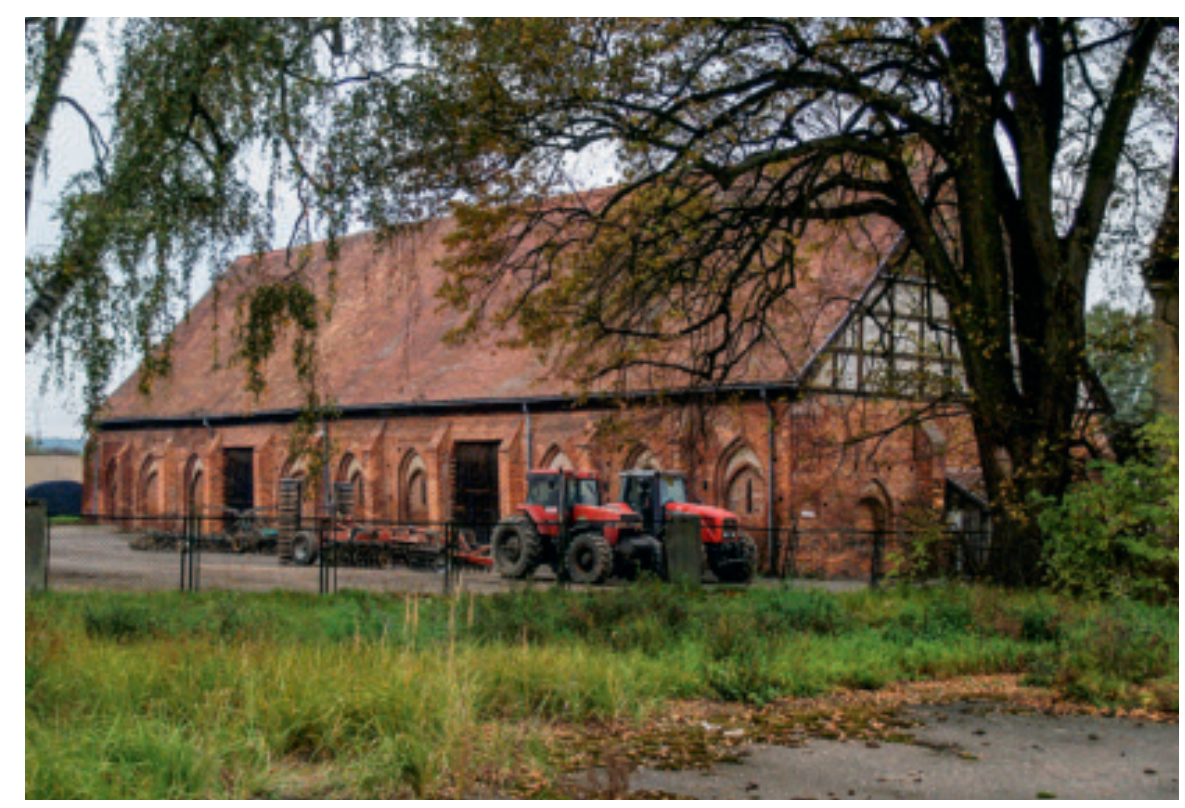

Fig. 16. Den store kornlade i Kolbatz. Nu er bygningen en del af stedets landbrugsskole. Ved mange cistercienserklostre blev der opført store ladebygninger i klostrets ydre gård. Ingen er bevaret i Danmark, men flere steder har man i Nordtyskland bevaret store grundmurede bygninger, der har været brugbare som landbrugsbygninger frem til vor tid. - Foto: HKK 2006.

The large granary in Kolbatz. The building is now part of the town's agricultural college. At many Cistercian abbeys, large barns were built in the outer yard. None have survived in Denmark, but in several places in northern Germany large brick-built structures still stand that have been usable as agricultural buildings up to the present day.

\section{Rostock og Wismar}

Som i Pommern begyndte Reformationen i Mecklenburg i de store hansebyer - i dette tilfælde Rostock og Wismar. I Rostock begyndte Joachim Slüter evangelisk prædiken i Sankt Peters Kirke fra 1523 og fremefter. ${ }^{51}$ Modsat situationen i forskellige andre byer besluttede rådet ganske uproblematisk i 1531, at byen skulle være protestantisk, og i september blev den katolske messe forbudt. Dominikanernes kloster blev lukket samme år, og nogle få år senere blev det taget i brug som latinskole. ${ }^{52}$ Dominikanerne var kommet til Rostock senest i 1256, hvor de fik overladt en grund langs bymuren. Her opførte de en treskibet hallekirke med langstrakt kor. Med tiden forsvandt klosterbygningerne til fordel for nye, og som det sidste blev kirken revet ned i $1831 .^{53}$

Franciskanerklostret fra 1265 ophørte i 1534 og blev genbrugt som hospital (fig. 18). I dag er det en skole for musik og teater og ganske vel bevaret 


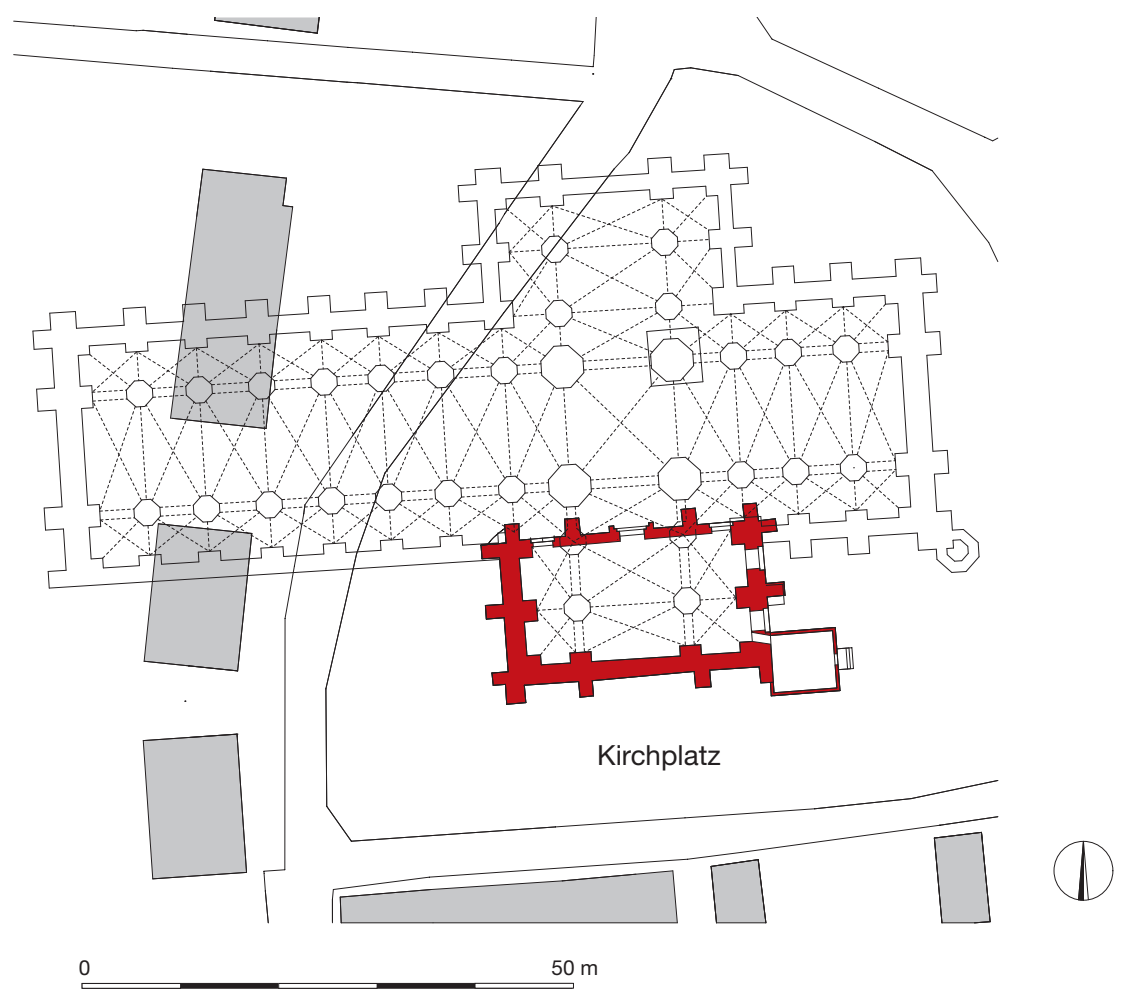

Fig. 17. Rekonstrueret grundplan af klosterkirken i Neuenkamp (Franzburg). Den $90 \mathrm{~m}$ lange kirke regnes for opført i perioden 1280-1340. Såvel skib som kor og tværskib var opført som en treskibet hallekirke med stor indvendig højde. - Tegning: Martin Ebert, efter Ebert \& Grundner 2009.

Reconstructed ground plan of the abbey church in Neuenkamp (Franzburg). The $90 \mathrm{~m}$ long church is thought to have been built in the period 1230-1340. The nave, the chancel and the transept were constructed as a three-aisled hall church of great internal height.

bortset fra kirken. ${ }^{54}$ De to klostergårde nord for kirken er begge forsynet med hvælvede korsgange - mod nord dog kun to smalle gange. Forholdet med de dobbelte klostergårde er af Matthias Untermann tolket som en offentlig gård med adgang for lægfolk og en privat gård kun for brødrene. ${ }^{55}$

På den anden side fortsatte det cisterciensiske nonnekloster Zum Heiligen Kreuz blot ændret til et lutheransk konvent i 1562 og eksisterede derefter frem til $1920 .{ }^{56}$ Det blev brugt til døtre af byens patricierfamilier. I dag er det et museum og et meget fint bevaret kloster (fig. 19). Klostret blev grundlagt $\mathrm{i}$ tiden omkring 1270 under medvirken af den danske enkedronning Margrete (kaldet Sprænghest), hendes fætter og borgere i Rostock. ${ }^{57}$. Klostret fik plads i et tyndt bebygget område op mod bymuren i syd, hvor det med tiden voksede til et meget stort anlæg med økonomibygninger og haver. 

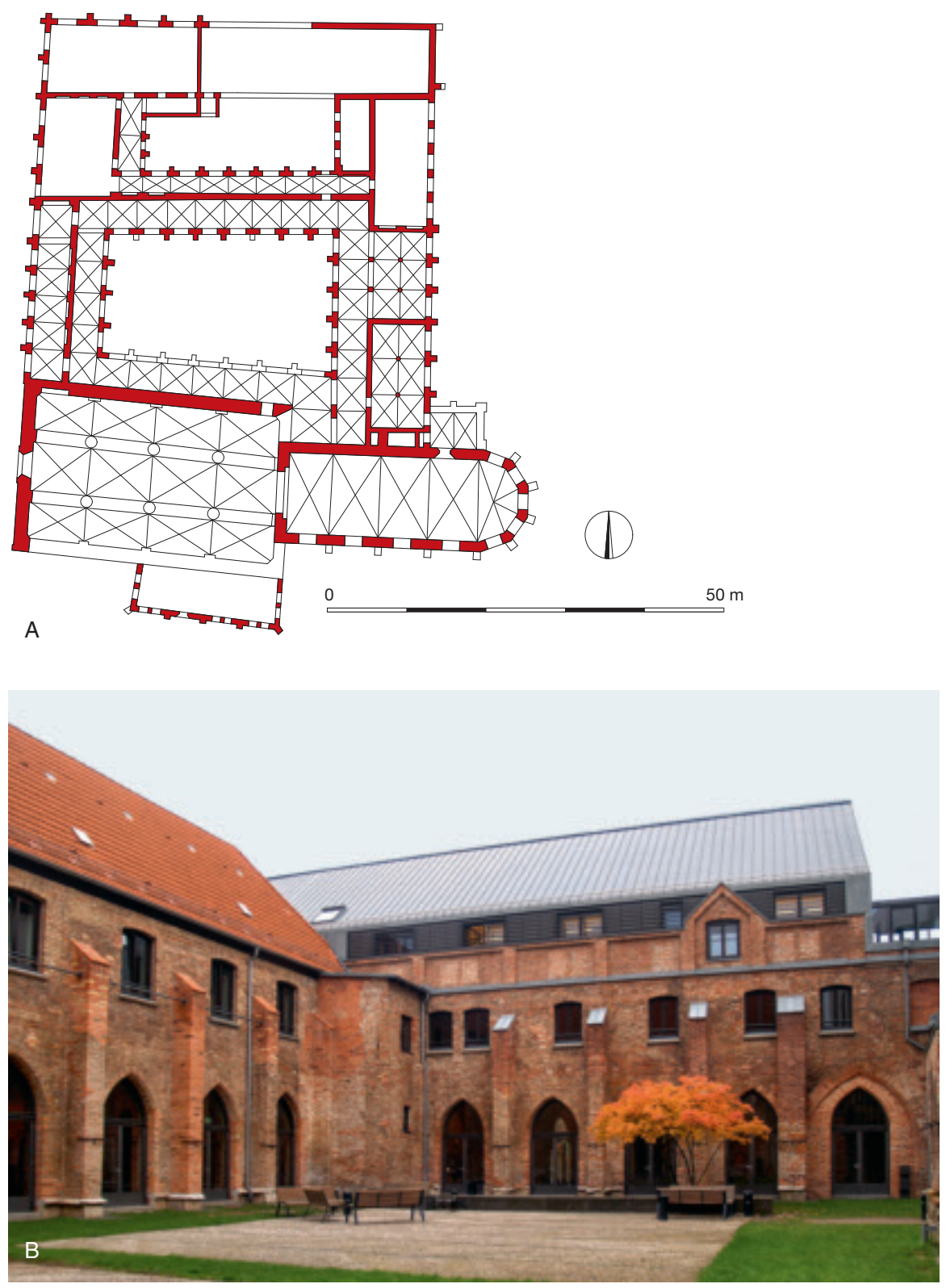

Fig. 18. Franciskanerklostret i Rostock. A) Rekonstrueret grundplan af det middelalderlige anlæg. B) Klostergården med korsgange set mod nordøst. Efter en brand i midten af 1200-tallet blev den treskibede hallekirke opført. I 13- og begyndelsen af 1400-tallet blev koret og hovedparten af klosterbygningerne nybygget. - Tegning: Martin Ebert, efter Ebert \& Grundner 2009. Foto: HKK 2006.

The Franciscan friary in Rostock. A) Reconstructed ground plan of the Medieval complex. B) The cloister garth with cloisters, seen looking northeast. After a fire in the mid-13th century, the three-aisled hall church was constructed. In the 14th and early 15 th century, the chancel and most of the abbey buildings were rebuilt. 

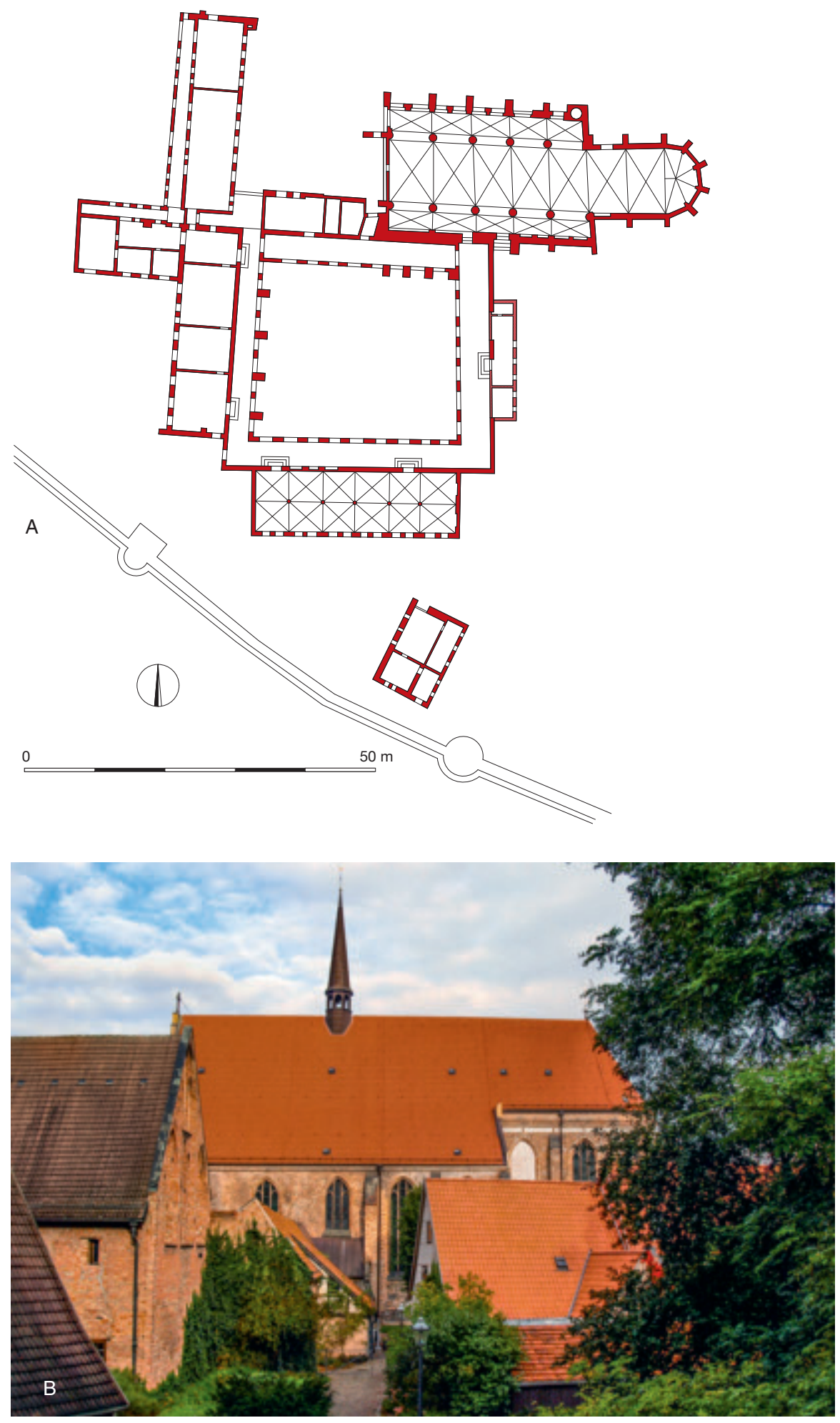
I 1524 et år senere end i Rostock blev evangelisk prædiken påbegyndt af Heinrich Never i Wismar. ${ }^{58}$ Han blev forstander for franciskanerklostret, som blev reformeret i 1527. Nogle brødre levede dog videre i bygningerne frem til 1541. Klostret blev omdannet til skole, men blev gradvist revet ned med kirken i løbet af 1800-tallet og de sidste rester i 1891/92 (fig. 20). Franciskanerklostret blev stiftet i 1251 nogenlunde midt i byen og fik den for Nordtyskland karakteristiske form med to klostergårde syd for kirken. ${ }^{59}$

Efter 1532 var alle medlemmer af byens råd protestanter, og Wismar var i princippet en evangelisk by, men dominikanernes konvent fik støtte fra hertugerne og fortsatte som et katolsk tiggerkloster frem til $1552 .{ }^{60}$ Efterfølgende blev bygningerne brugt som vajsenhus og fattiggård for i 1880 efter en ombygning at blive brugt som skole. Af det middelalderlige bygningskompleks er i dag kun koret bevaret (fig. 21). Klostret blev grundlagt i 1292 på en lidt dårlig byggegrund tæt ved bymuren i en udvidelse af byrummet. Overraskende hurtigt rejstes her et stort bygningskompleks (fig. 22).

Gennem reformationsårene vendte prædikanten Heinrich Never sig mere og mere mod Zwinglis teologi, og efter nogen diskussion og kritik fra Luther og Bugenhagen blev han afsat som prædikant i $1541 .^{61}$

I de mindre byer levede indbyggerne efter 1534 med to konfessioner side om side. I byer med kun en sognekirke som i Malchin eller Neubrandenburg delte katolikkerne og protestanterne kirken efter aftale på bestemte tidspunkter. I andre byer med to sognekirker som eksempelvis Friedland, Güstrow og Parchim fik hver part sin egen kirke og måtte til gengæld ikke bruge den anden. ${ }^{62}$

$\longleftarrow$ Fig. 19. Klostret Zum Heiligen Kreuz A) Plan. Cistercienserkirken blev nyopført i midten af 1300-tallet med forbillede i områdets tiggerklosterkirker. Klosterbygningerne er i strukturen lidt ældre og planlagt til en kirke placeret lidt længere mod vest. Derfor ligger vestfløjen med nonnernes dormitorium/celler forskudt mod vest. B) Klosterkirken set fra bymuren i syd. Til venstre gavlen af klostrets sydfløj med refektorium. - Tegning: Martin Ebert, efter Ebert \& Grundner 2009. Foto: HKK 2006.

The nunnery Zum Heiligen Kreuz. A) Plan. The Cistercian church was rebuilt in the middle of the 14th century, modelled on the area's mendicant churches. The convent buildings are slightly earlier in construction and planned to accommodate a church located a little further west. As a consequence, the west wing containing the nuns' dormitory/cells is displaced westwards. B) The abbey church, seen from the town wall to the south. On the left, the gable of the south wing of the abbey containing the refectory. 


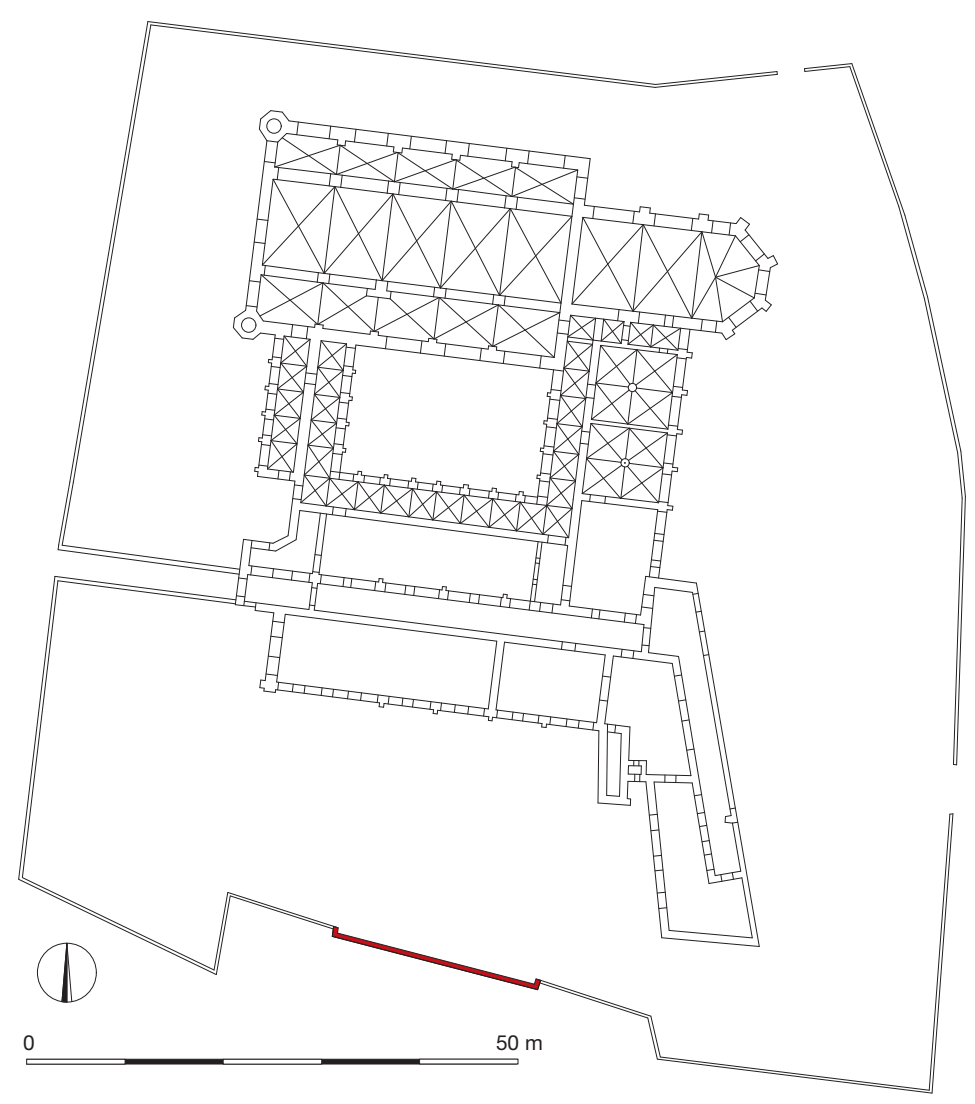

Fig. 20. Rekonstrueret plan af franciskanerklostret i Wismar. Kirken har haft den typiske nordtyske form som en treskibet hallekirke med et langstrakt kor. Det antages, at det søndre sideskib har været delt $\mathrm{i}$ to stokværk, således at korsgangen ind mod kirken har forløbet i sideskibets nederste stokværk. - Tegning: Martin Ebert, efter Ebert \& Grundner 2009.

Reconstructed plan of the Franciscan friary in Wismar. The church had a typically North German form as a three-aisled hall church with an extended chancel. It is presumed that the southern side aisle has been divided into two storeys, such that the cloister in towards the church ran inside the side aisle's lower storey.

\section{Den endelige Reformation i Mecklenburg}

Situationen skiftede efter hertug Albrecht VII's død i 1547. Hans efterfølger Johann Albrecht I samlede sammen med Heinrich V prælaterne, adelen og byerne til et møde "Landtag" ved Sagedorfer bro ved Sternberg i 1549, hvor de forkastede et krav fra den katolske kejser Karl V om at acceptere kravene i Det Augsburgske Interrim om at vende tilbage til den katolske tro, indtil et nyt koncil havde fundet sted. I stedet havde de udråbt hele Mecklenburg til et protestantisk hertugdømme. ${ }^{63}$ Beslutningen førte til lukning af de tilbageblevne klostre i Mecklenburg. ${ }^{64}$ En endelig ordning for kirken blev der dog først skabt 


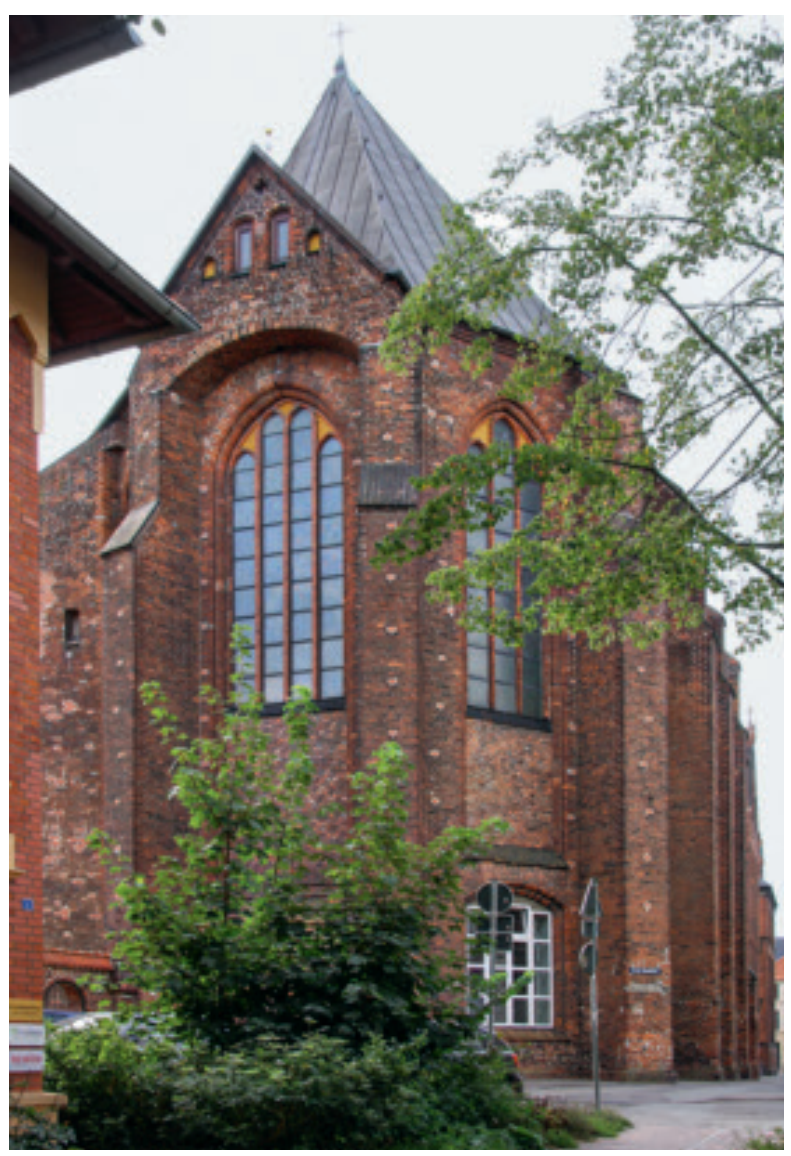

Fig. 21. Dominkanerklostret i Wismars kor fra 1397. Ved ombygningen o. 1880 blev det høje kor delt i to etager. - Foto: HKK 2016.

The chancel of the Dominican friary in Wismar from 1397. In the renovation work around 1880 the high chancel was divided into two storeys.

enighed om i 1552. Denne "Kirchenordnung" havde et afsnit om klostrenes fremtid. ${ }^{65}$ Nonner og munke havde frit lov til at forlade deres kloster. Der skulle holdes evangeliske gudstjenester i klosterkirkerne, nye novicer måtte ikke indtræde i mandsklostrene, men var tilladt i nonneklostrene. Ordensdragt og klosterløfter blev forbudt.

Tiggerklostrene blev overtaget af byrådene, og de fleste omdannet til skoler og hospitaler. Lukningen blev dog en langtrukken affære (fig. 23). Franciskanerklostret i Schwerin blev senere revet ned på grund af en udbygning af byens befæstning. ${ }^{66}$ Ellers blev tiggerordenernes klostre i det mindste i de større byer bevaret ganske godt frem til 1800-tallet, hvor en del forsvandt til fordel for den tids byudvikling. ${ }^{67} \mathrm{Vi}$ har således et bedre kendskab til tiggerklostrenes udformning i Mecklenburg-Vorpommern end i Danmark, skønt der var langt flere af den type klostre her i landet. 


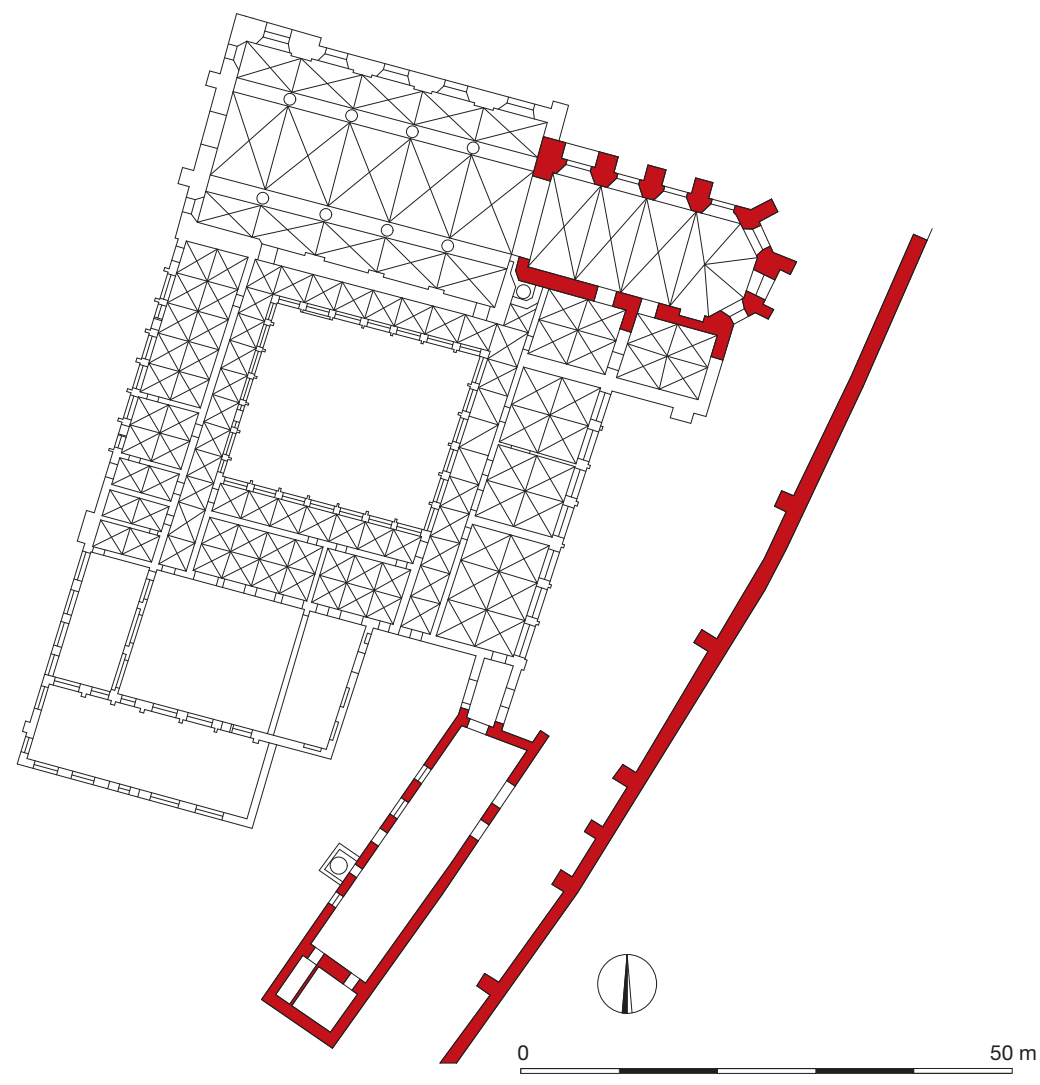

Fig. 22. Dominikanerklostret i Wismar. Rekonstrueret grundplan med treskibet hallekirke og store klosterfløje fra første tredjedel af 1300-tallet. Koret blev senere nybygget. - Tegning: Martin Ebert, efter Ebert \& Grundner 2009.

The Dominican friary in Wismar. Reconstructed ground plan with three-aisled hall church and large abbey wings from the first third of the 14th century. The choir was later rebuilt.

$\begin{array}{lll}\begin{array}{l}\text { Lukningen af tiggerklostre i Mecklenburg The closing of friaries in Mecklenburg } \\ 1527\end{array} & \text { Sternberg: augustinereremitter austin friar } & \text { (boliger flats) } \\ 1531 & \text { Rostock: dominikanere dominicans } & \text { (skole school) } \\ 1534 & \text { Rostock: franciskanere franciscans } & \text { (hospital hospital) } \\ 1541 & \text { Wismar: franciskanere franciscans } & \text { (skole school) } \\ 1543 & \text { Röbel: dominikanere dominicans } & \text { (nedrevet demolished) } \\ & & \\ 1549 & \text { Reformationen i Mecklenburg Reformation } & \text { Mecklenburg } \\ 1550 & \text { Güstrow: franciskanere franciscans } & \text { (nedrevet demolished) } \\ 1552 & \text { Wismar: dominikanere dominicans } & \text { (hospital hospital) } \\ 1552 & \text { Schwerin: franciskanere franciscans } & \text { (nedrevet demolished) } \\ 1552 & \text { Parchim: franciskanere franciscans } & \text { (skole school) } \\ 1552 & \text { Neubrandenburg: franciskanere franciscans } & \text { (hospital hospital) }\end{array}$

Fig. 23. Oversigt over nedlæggelsen af tiggerklostrene i Mecklenburg med angivelse af den efterfølgende brug. Halvdelen blev nedlagt før den endelige Reformation.

Overview of the dissolution of the mendicant friaries in Mecklenburg, and their subsequent use. More than half were abolished prior to the actual Reformation. 


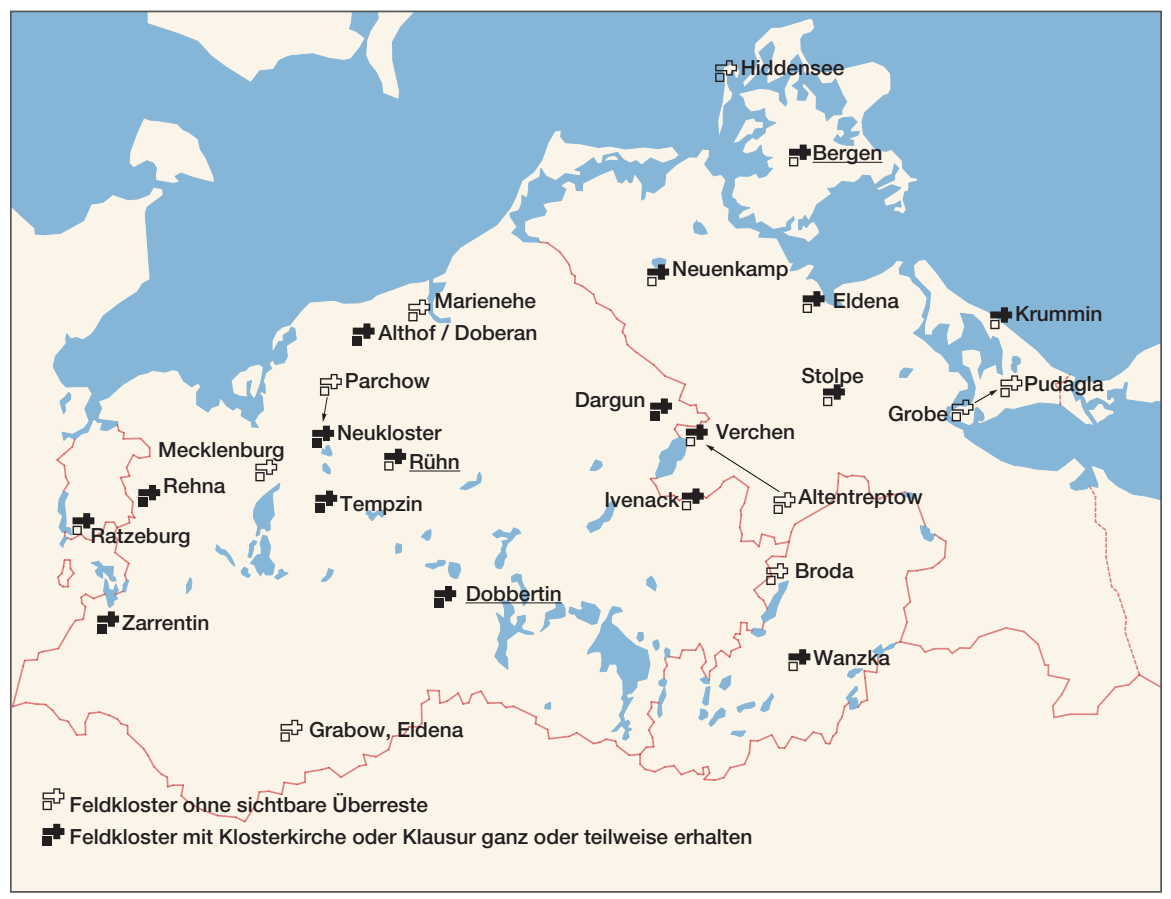

Fig. 24. Landklostre i Mecklenburg-Vorpommern. Nonneklostre i begge områder, der blev omdannet til lutheranske stiftelser, er understreget.

Rural monasteries in Mecklenburg-Vorpommern. The nunneries in both areas that were converted into Lutheran foundations are underlined.

For adelens skyld blev en række nonneklostre ikke lukket og var stadig til rådighed for deres ugifte døtre. I 1572 blev de reduceret i antal og ændret til lutherske "Damenstifte" uden klosterløfte og ordensdragt (fig. 24 og fig. 3). Dette skete for klostrene i Dobbertin, Malchow, Rühn og Ribnitz. ${ }^{68}$ I Dobbertin, Ribnitz og Rühn er der bevaret betydelige dele af de middelalderlige klostre, der i dag benyttes til ret forskellige formål (fig. 25). I Malchow er kirke og klosterbygninger om- eller nybygget i 1800-tallet. Cisterciensernonneklostret Zum Heiligen Kreuz i Rostock blev som nævnt bevaret for byens skyld for patricierfamiliernes ugifte døtre. Alle fungerede frem til 1918 eller $1920{ }^{69}$

De andre nonneklostre blev lukket på forskellige tidspunkter i anden halvdel af 1500-tallet. ${ }^{70}$ Blandt disse var cisterciensernonneklostret Sonnenkamp i Neukloster. Det var oprindelig stiftet som et benediktinerkloster, men overgik til cistercienserordenen og blev i 1219 flyttet til det nuværende sted. ${ }^{71}$ Efter at nonnerne var uddøde, blev kirken brugt som sognekirke, mens klosterbygningerne blev revet ned (fig. 26). Klosterkirken hører til blandt Mecklenburgs ældste monumentale kirkebygninger (fig. 27). 


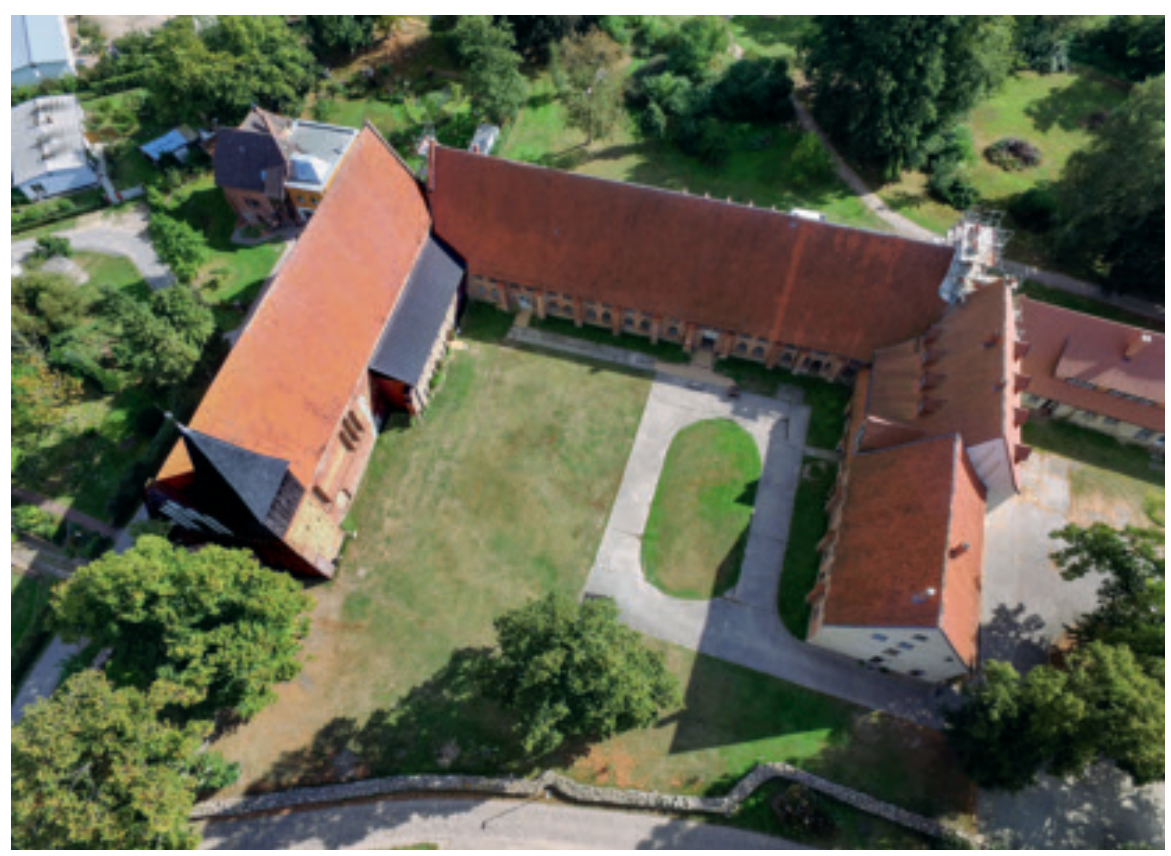

Fig. 25. Cisterciensernonnekloster Rühn set mod øst fra luften. Den langstrakte (45 m) og enskibede kirke (til venstre) og de øvrige bevarede klosterbygninger stammer fra midten af 1200-tallet. Formentlig har klostergården aldrig været lukket. Korsgangen langs kirken førte fra nonnernes dormitorium i østfløjen frem til det $25 \mathrm{~m}$ lange nonnepulpitur i kirkens vestende. - Foto: Wikimedia Commons 2016.

The Cistercian nunnery of Rühn, seen from the air, looking east. The extended ( $45 \mathrm{~m}$ long) single-aisled church (on the left) and the other surviving abbey buildings originate from the mid-13th century. The cloister garth has probably never been closed. The cloister alongside the church led from the nuns' dormitory in the east wing to the $25 \mathrm{~m}$ long nun's gallery at the western end of the church.

Ifølge den nævnte kirkeordning af 1552 skulle der gennemføres visitatser over hele hertugdømmet med introduktion af de protestantiske former. Kartheuserne i Marienehe udenfor Rostock modsatte sig og blokerede porten; men hertug Johann Albrecht I angreb karteuserklostret med en hær på 300 landsknægte og ødelagde efterfølgende bygningerne totalt. ${ }^{72}$ Nonnerne i Dobbertin var ligeledes modstandere af reformen og forsvarede deres kloster, således at det først i 1562 blev muligt at gennemføre Reformationen i Dobbertin. ${ }^{73}$

Kun ganske få mandsklostre havde overlevet frem til den endelige Reformation i Mecklenburg. Bortset fra to kommanderier fra Johanniterordenen blev de få tilbageværende hurtigt lukket i 1552 og godset overtaget af hertugerne. ${ }^{74}$ De vigtigste klostre var cistercienserabbedierne i Dargun og Doberan. I 1556 


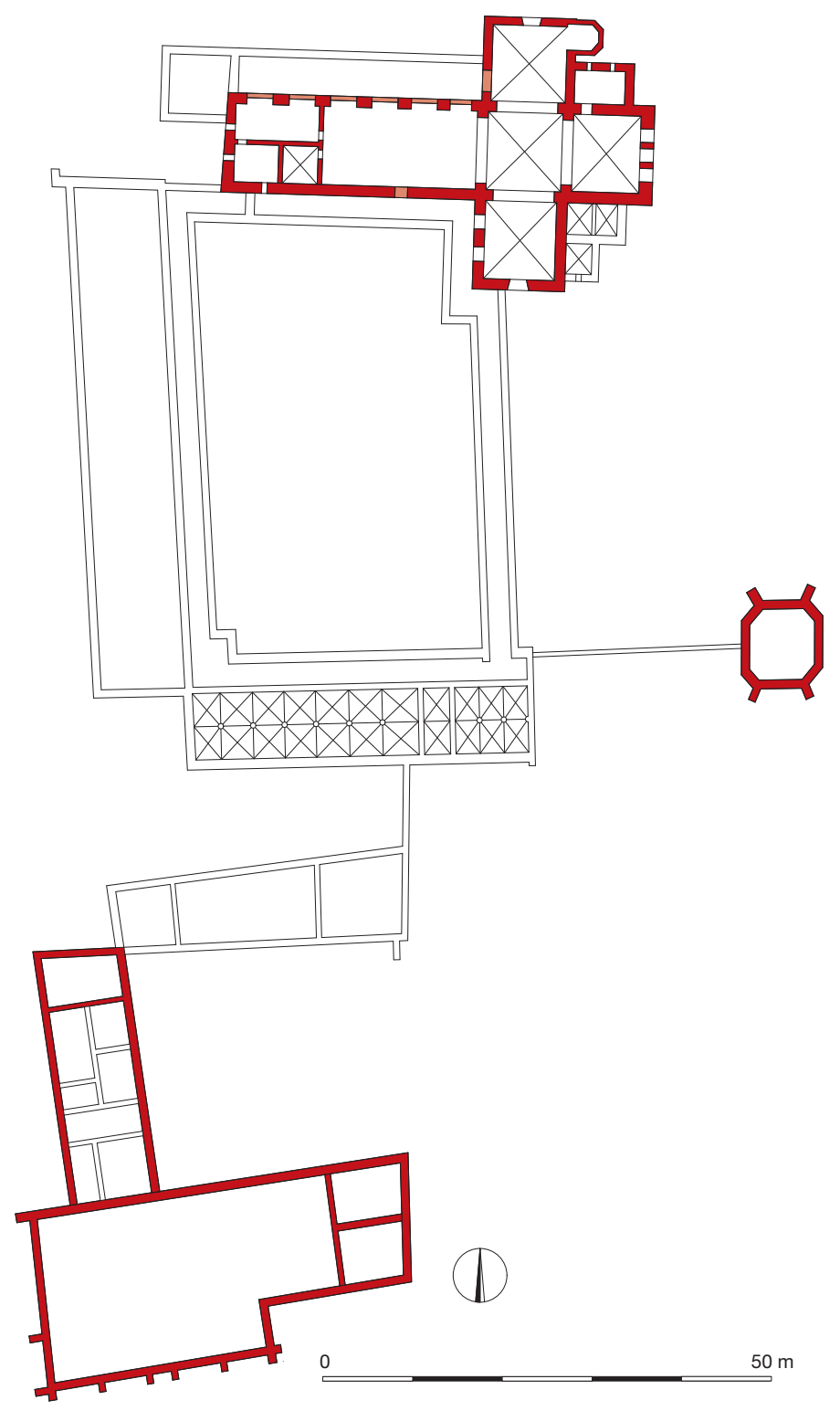

Fig. 26. Rekonstrueret plan af nonneklostet Sonnenkamp i Neukloster. Den store klosterkirke var udformet med tværskib og en basilika med sideskib kun mod nord. Nonnerne holdt til i den store vestfløj, hvorfra der må have været adgang til et nonnepulpitur i skibets vestende. Syd for det egentlige klosteranlæg er der bl.a. bevaret et "Probstei", hvor den verdslige administrator af klostergodset boede. - Tegning: Martin Ebert, efter Ebert \& Grundner 2009.

Reconstructed plan of the nunnery in Sonnenkamp, Neukloster. The large church was built with a transept and a basilica with side aisle only to the north. The nuns lived in the large west wing from where there must have been access to a nun's gallery at the western end of the nave. To the south of the actual monastery complex there is also a preserved "Probstei", where the secular administrator of the monastery estate lived. 
overgik Dargun til hertug Ulrich af Güstrow, som omdannede bygningerne til et stort slot. ${ }^{75}$ Det udbrændte totalt ved en påsat brand den 1. maj 1945.

Efter visitationen af Doberan i 1552 forlod munkene stedet og rejste til datterklostret Pelplin i Polen. ${ }^{76}$ Den hertugelige foged begyndte derefter at nedbryde klostret, men blev stoppet af den fremtidige hertug Ulrich på grund af de fyrstelige gravmæler i kirken. I de kommende århundreder fortsatte kirken med at blive brugt som gravkirke for den hertugelige familie. Takket være dette er denne meget store klosterkirke stadig bevaret (fig. 28). Kirken hører til de største og mest avancerede cistercienserkirker overhovedet og et væsentligt monument i generationen af højgotiske kirker i Nordtyskland o. år 1300. ${ }^{77}$ Af det centrale klosteranlæg (klausuren) er kun østfløjens østmur bevaret, mens der på den store klostergrund står betydelige dele af forskellige økonomibygninger (fig. 29).

Fig. 27. Østgavlen på klosterkirken i Sonnenkamp. Dendrokronologiske undersøgelser har vist, at taget over østpartiet med kor og tværskib blev rejst i 1244, og at skibet blev færdigbygget i 1251. - Foto: HKK 2006.

The east gable of the abbey church in Sonnenkamp. Dendrochronological investigations have shown that the roof over the eastern section, containing the chancel and transept, was constructed in 1244 and that the nave was completed in 1251 .

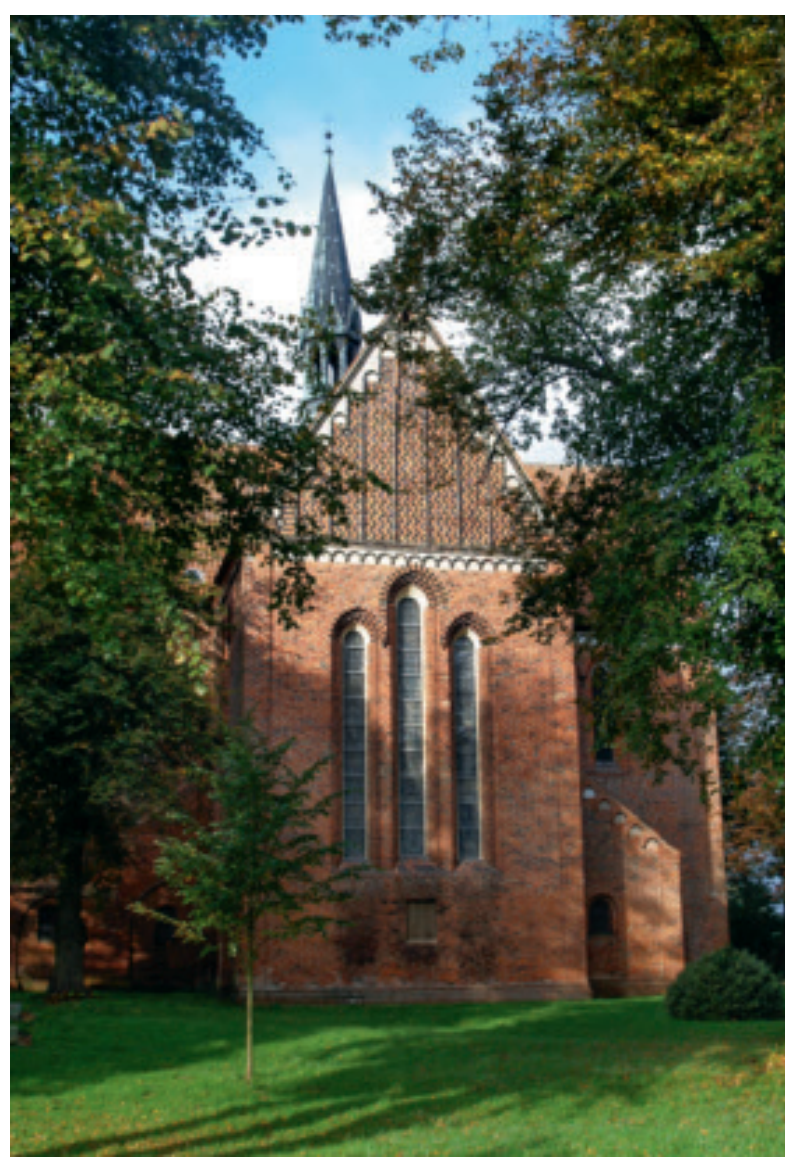




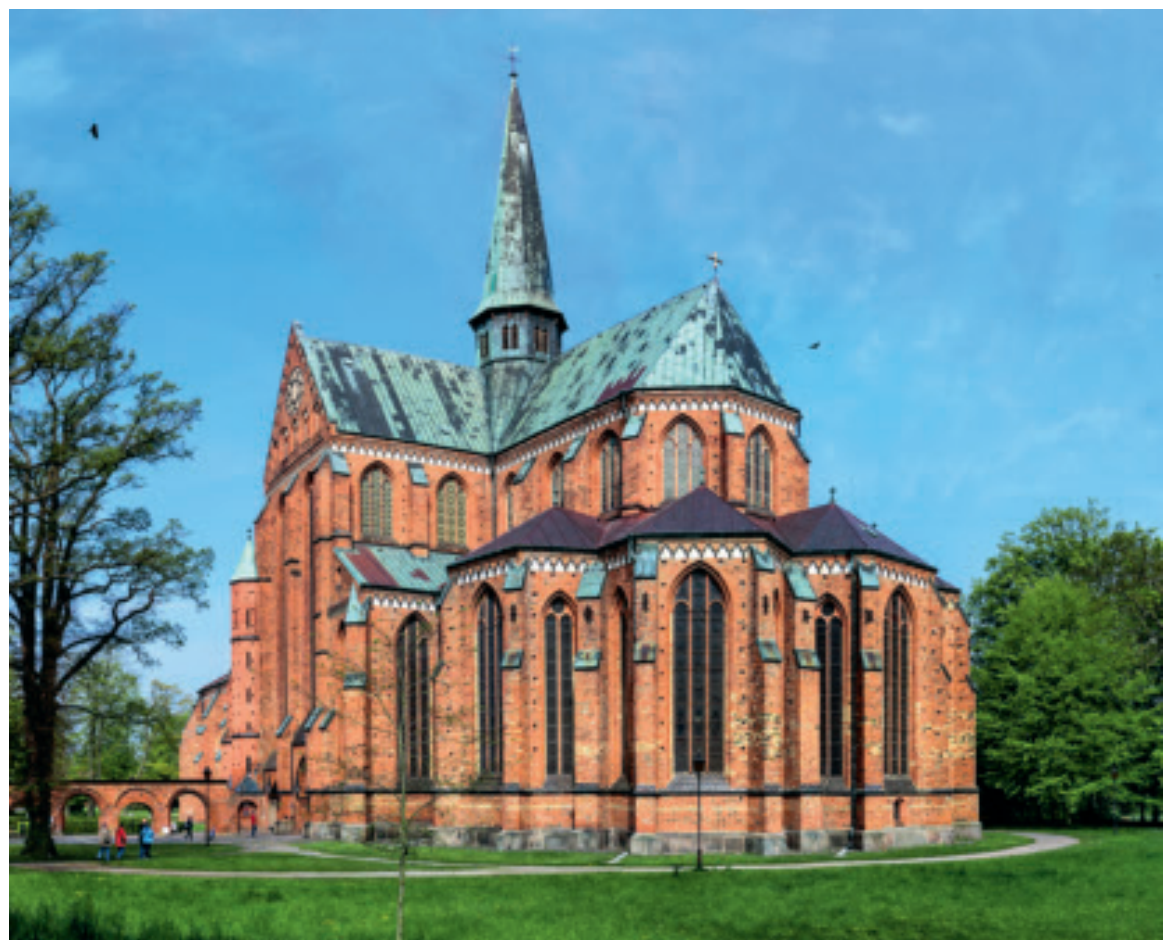

Fig. 28. Klosterkirken i Doberan set fra sydøst. Kirken blev nyopført i slutningen af 1200-tallet med radierende kapeller omkring et polygonalt kor efter forbilleder fra domkirken og St. Marienkirchen i Lübeck. Planløsningen er ganske ekstravagant i forhold til cisterciensernes postulerede beskedenhed i byggeriet. Den katedrallignende kirke er Tysklands største cistercienserkirke. I nyere tid har det vist sig, at kirken er opført i en løbende byggegang med tagværker over højkirken både i kor og skib dateret til 1297. - Foto: Schiwago, Wikipedia CCA-SA 2012.

The abbey church in Doberan, seen from the southeast. The church was newly built/ rebuilt at the end of the 13th century, with radiating chapels around a polygonal chancel, modelled on the cathedral and St. Mary's church in Lübeck. The layout is quite extravagant, given the Cistercians' postulated modesty in building works. The cathedral-like building is Germany's largest Cistercian church. In recent times, it has become apparent that it was constructed in one continuous building operation with the roof constructions over both the choir and nave dated to 1297.

\section{Den endelige Reformation i Danmark}

I reformationsåret 1536 skete der ikke så meget vedrørende klostrene, og det blev besluttet, at omkring de jordejende klostre, prælaturer og præbender skulle den fremtidige skæbne afgøres af en kommission. ${ }^{78}$ Dette skete dog aldrig. Derfor fortsatte de fleste klostre i evangelisk form uden nogen fælles beslutning, men blev behandlet som om de tilhørte kronen, og de fik ikke tilladelse til 


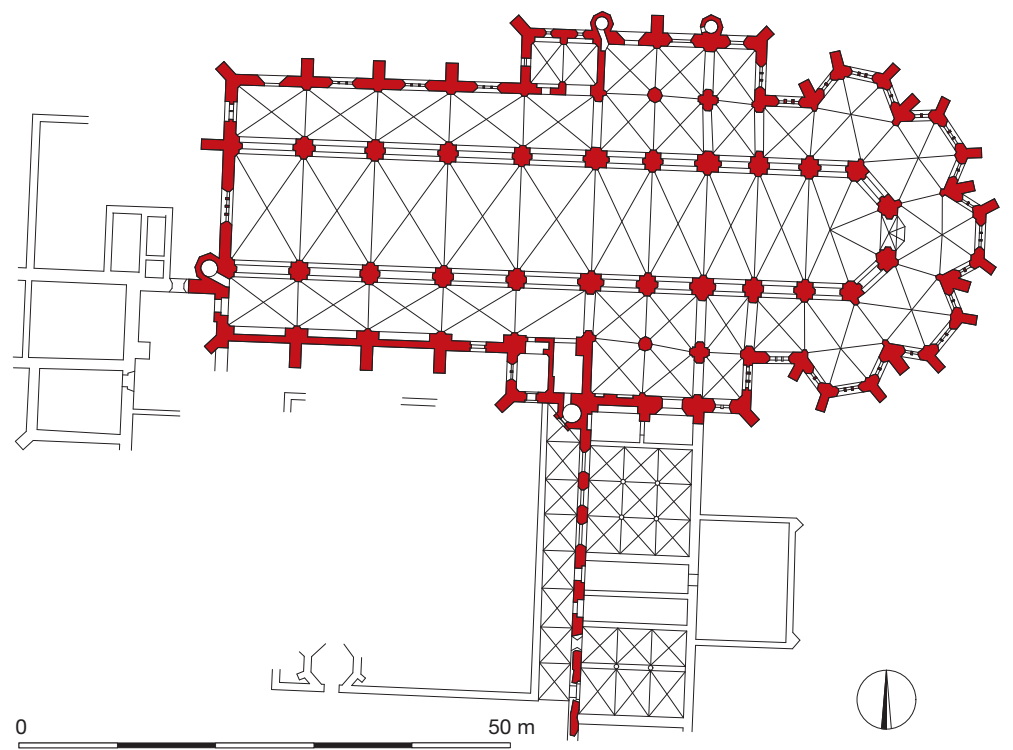

Fig. 29. Grundplan af cistercienserklostret i Doberan. Kirkens planløsning har haft stor betydning for udformningen af hovedkirkerne i København (Vor Frue) og Malmø (Sankt Petri). - Tegning: Martin Ebert, efter Ebert \& Grundner 2009.

Ground plan of the Cistercian abbey in Doberan. The church's layout has had great significance for the form of the main churches in Copenhagen (Our Lady's) and Malmö (St. Peter's).

hverken at sælge eller pantsætte ejendomme. ${ }^{79}$ Munkene var frie til at forlade klostrene; men hvis de forblev, skulle de lytte til forelæsninger om evangeliet. I virkeligheden var dette dog ikke væsentlige nye reguleringer.

I det følgende år udkom Kirkeordinansen på latin og to år senere på dansk med de fremtidige bestemmelser. Heri blev tiggerordenerne forbudt i Danmark. ${ }^{80}$ Gamle brødre fik lov at blive i landet, men uden ordensdragt.

\section{Klosterbygningernes skæbne i Danmark}

Skønt en stor del af tiggerklostrene og andre byklostre var planlagt til at genbruges som hospitaler og skoler, blev de fleste alligevel revet ned eller forsvandt gradvis på anden måde i tiden efter Reformationen. Så bortset fra nogle kirker er kun en ret begrænset del af bygningerne stadig stående eller kendt på anden måde end fra arkæologiske udgravninger.

Et ønske fra adelen om at lade nogle nonneklostre fortsætte i evangelisk form blev kun prøvet i Maribo med store problemer frem til 1621. ${ }^{81}$ Stiftelsen blev opgivet, og efterfølgende forsvandt klosterbygningerne. I stedet blev adelen 


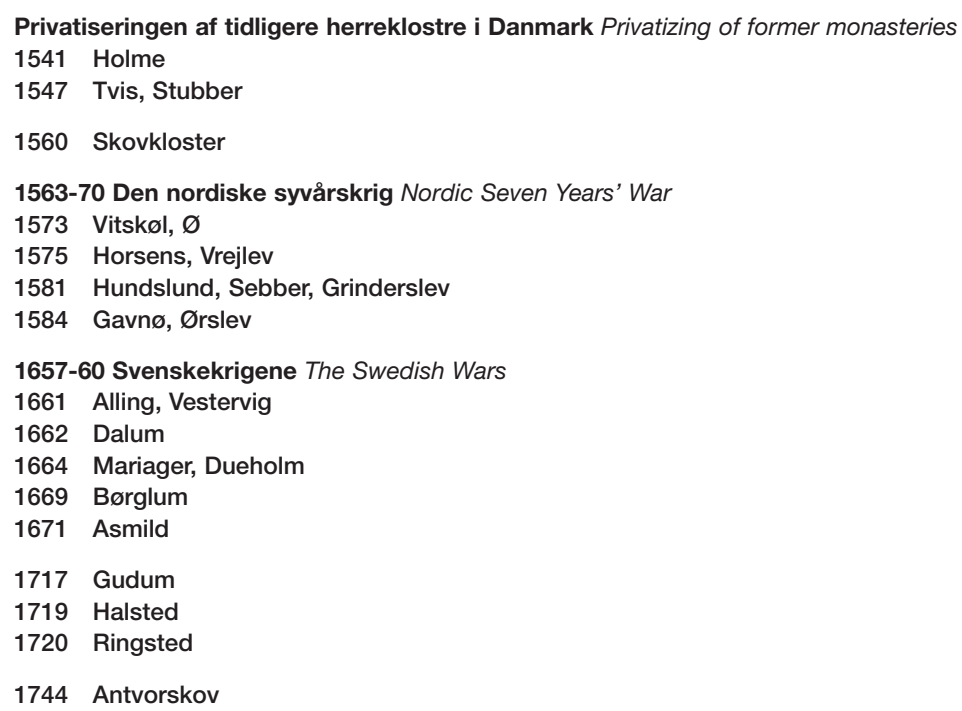

Fig. 30. Privatiseringen af de danske herreklostre.

The privatisation of the Danish abbeys.

nødt til selv at betale for at oprette nogle institutioner for deres ugifte døtre, de såkaldte adelige jomfruklostre. Disse huse er således i modsætning til de tyske uden forbindelse tilbage til middelalderlige klostre.

Kort efter Reformationen i Danmark blev en stor del af de jordejende klostre lukket. Det gjaldt specielt augustinernes, præmonstratensernes, og johanniternes konventer med kannikker ordineret som præster, der fremover i givet fald ville kunne arbejde som sådan i de omgivende sogne. ${ }^{82}$ Sandsynligvis havde nogle af dem haft dette arbejde tidligere i kirker, der var inkorporeret $\mathrm{i}$ klostrene. De fleste klostre fortsatte i kortere eller længere tid med enten en abbed eller en verdslig lensmand, men resultatet af begge løsninger var det samme. I det lange løb uden nye novicer døde nonner og munke ud, og så var klostrene blot ordinære kongelige len.

Gennem de næste 200 år blev en stor del af klostrene frasolgt kronen til private personer. Vi kan se, at de fleste blev solgt i bestemte tidsrum (fig. 30). De to væsentligste grupper var i perioden 1573-84, der fulgte efter den Nordiske Syvårskrig, og perioden 1661-71 i årene efter Svenskekrigene. Det var perioder, hvor kronen manglede penge til at betale gælden fra krigene. ${ }^{83}$ Tilsvarende form for privatisering ses ikke i Mecklenburg-Vorpommern, hvor nogle få klostre forblev i fyrsternes besiddelse og blev ombygget til slotte, mens de andre hurtigt forsvandt helt. ${ }^{84}$ 
Klosterbygningerne blev i Danmark genbrugt som residenser for private familier. De er selvfølgelig blevet moderniseret noget fra tid til anden, men meget er stadig bevaret, skønt det ikke er uden problemer, at så mange middelalderlige klostre stadig er og har været i privat besiddelse.

\section{Hansebyerne Hamburg, Lübeck, Lüneburg og Danzig}

\section{Hamburg}

Allerede i 1518 nåede Martin Luthers tanker til Hamburg, og i 1522 begyndte den tidligere korherre af præmonstratenserordenen, Johann Wiedenbrügge, med evangeliske prædikener i byen. De første protestantiske bøger fra Hamburg blev trykt allerede i 1522/23. Et meget betydningsfuldt skridt for Reformationen i Hamburg var ankomsten i 1523 af franciskanerbroderen Stephan Kempke fra Rostock, som prædikede i franciskanerkirken Sankt Maria Magdalene i Hamburg.

Domkapitlet var naturligvis imod den lutheranske bevægelse, og det gav meget uro i byen. Byrådet besluttede derfor at afholde en offentlig debat, "Disputation", om den rigtige forståelse af kristendommen. Den første blev afholdt i maj 1527 og den anden i april 1528. Begge debatter blev vundet af protestanterne. Efter den anden Disputation måtte fem højtplacerede prælater forlade Hamburg, og den katolske messe blev forbudt i byen.

Året efter vedtog indbyggerne og rådet i Hamburg en såkaldt "Kirchenordnung" skrevet af Johannes Bugenhagen, og det blev fastslået, at kun den lutherske tro kunne tolereres i byen.

Byen Hamburg havde to store klostre ${ }^{85}$ Franciskanerklostret var indviet til Sankt Maria Magdalena og grundlagt mellem 1227 og 1239 og havde mange bygninger arrangeret omkring to klostergårde. Dominikanernes kloster fra 1235/36 indviet til både Johannes Døberen og Johannes Evangelist havde ligeledes bygningerne placeret rundt om to gårde (fig. 31). Måske var begge anlæg indrettet med korsgangen nærmest kirken åben for offentligheden, mens den fjerne var forbeholdt brødrene alene ${ }^{86}$ Klostrets nordside grænsede op til den xldre bymur ved Klosterfleet.

Efter Reformationen forlod dominikanerne deres kloster i 1529, og bygningerne blev delvis overtaget af nogle nonner fra det ødelagte kloster i Harvestedhude uden for byen. I Hamburg dannede de et protestantisk Damenstift. Andre dele af klostret blev indrettet til en skole. Franciskanerklostret blev efter 1529 benyttet som hospital for kvinder. Begge klosteranlæg blev revet ned i midten af 1800 -tallet. 


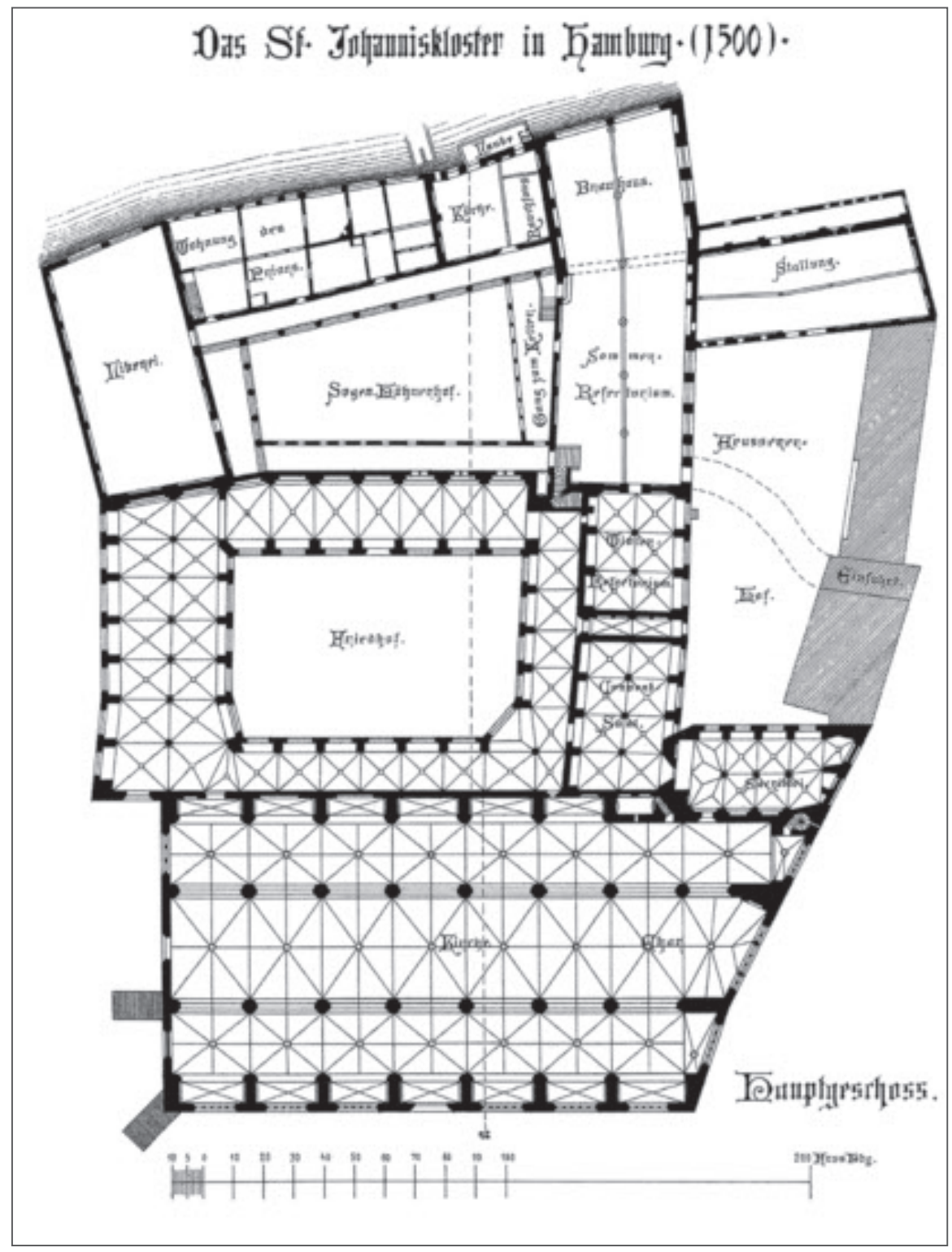

Fig. 31. Grundplan af dominikanerklostret i Hamburg. Den store treskibede kirke med kapelrækker mellem stræbepillerne blev genopført efter en brand i 1424. Korets skrå afslutning skyldes, at kirken blev bygget helt ud til gaden Hinter dem Breitengiebel. Vestfløjen og dele af korsgangen var nok fra samme tid som kirken, mens andre dele af klostret blev opført i 1300-tallet. - Efter Först 2014.

Ground plan of the Dominican friary in Hamburg. The large three-aisled church with rows of chapels in between the buttresses was rebuilt after a fire in 1424. The oblique termination of the choir results from the church being built all the way out to the street Hinter dem Breitengiebel. The west wing and parts of the cloister are probably from the same time as the church, while other parts of the abbey were built in the 14th century. 


\section{Lübeck}

Luthers ideer vandt også tidligt indpas i Lübeck, måske allerede fra $1518 .{ }^{87} \mathrm{De}$ nye tanker blev fremmet af en stor modvilje mod biskoppen, domkapitlet og misbruget blandt det førende kleresi. På den anden side havde byrådet stærke relationer til den højere gejstlighed og forblev faste katolikker, så der opstod et socialt gab mellem de almindelige borgere i byen og medlemmerne af byrådet. Gennem nogle år reagerede biskoppen og domkapitlet og rådet hårdt overfor lutheranske prædikanter, og i 1526 blev en mængde lutherske skrifter brændt i offentlighed på torvet.

Situationen ændredes dog i de tidlige 1530 'ere, fordi byrådet ønskede at hæve skatterne med henblik på en militær oprustning. I den anledning havde man behov for tilslutning fra en større del af befolkningen. Derfor blev det den 30 . juni 1530 besluttet, at i alle kirker bortset fra domkirken skulle evangeliske gudstjenester erstatte den katolske messe. Året efter udfærdigede Johannes Bugenhagen den nye ordning: Der Keyserliken Stadt Lübeck Christlike Ordeninge for byen. Byrådet blev herved den religiøse leder af kirkerne i Lübeck. Reformationen i Lübeck begyndte som en religiøs bevægelse, men kampen mod rådet medførte også en social og politisk forandring af bystyret med langt større indflydelse fra almindelige borgere. Det er dog en anden historie.

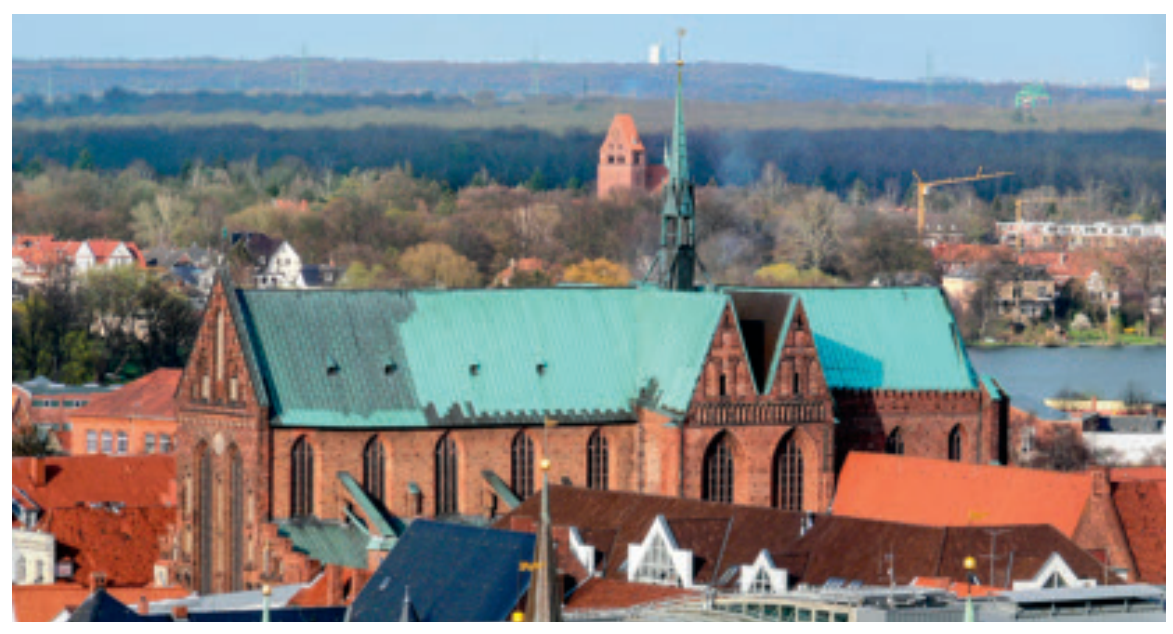

Fig. 32. Franciskanerkirken i Lübeck set fra syd. Opført som en basilika med meget højt midterskib, tværskib og et par radierende kapeller afviger denne højgotiske kirke således på flere punkter fra de øvrige tiggerklosterkirker i Nordtyskland. - Foto: Andres Praefcke, Wikimedia 2007.

The Franciscan church in Lübeck, seen from the south. Constructed as a basilica with a very high nave, transept and a couple of radiating chapels, this High-Gothic church deviates in several aspects from the other mendicant churches of northern Germany. 
Fig. 33. Grundplan af franciskanerklostret i Lübeck (1832). Frem til en ombygning af skolen o. 1880 var det store klosteranlæg velbevaret. - Efter Schneider 2014.

Ground plan of the Franciscan friary in Lübeck (1832). Up until the alteration of the school around 1880, the large friary complex was well preserved.

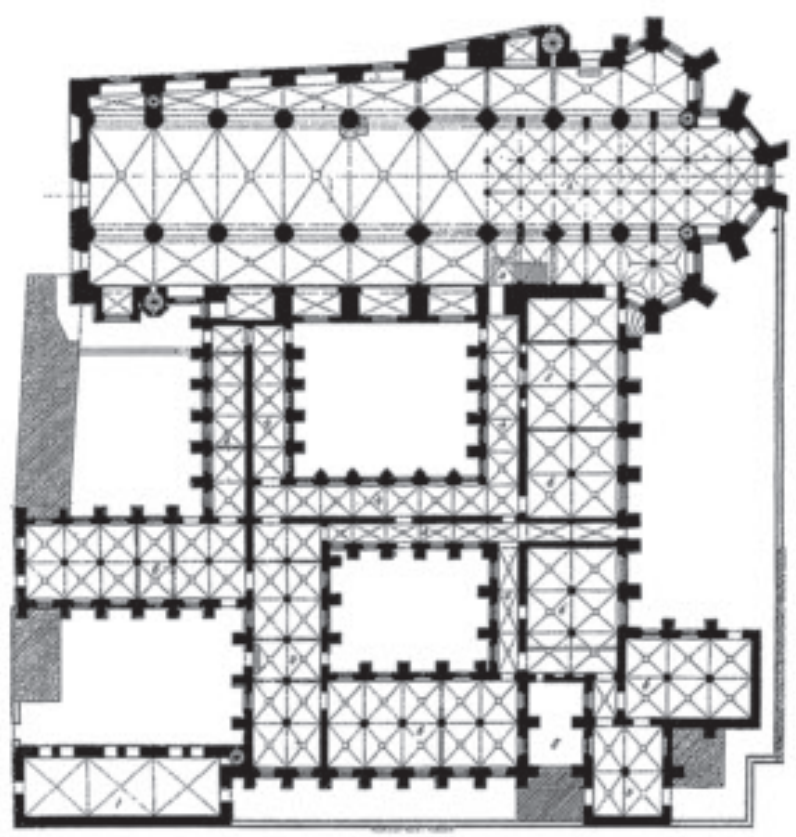

Ved Reformationen var der fire klostre i Lübeck. Det ældste Sankt Johannes var stiftet $\mathrm{i}$ årene efter 1173 som et benediktinerabbedi. ${ }^{88}$ Kort efter erobringen af den danske borg i Lübeck og slaget ved Bornhøved i 1226/27 blev konventet formentlig på grund af dets nære tilknytning til det danske herredømme bedt om at flytte til Cismar i Østholsten, hvilket det dog først gjorde i 1256. Munkene blev i klostret efterfulgt af nonner af cistercienserordenen. Nonneklostret Sankt Johannes fyldte et stort område op mod bymuren i byens østlige del. De havde en stor kirke og en mængde bygninger. Efter Reformationen blev dette store kloster omdannet til et evangelisk Damenstift. Institutionen blev opgivet i begyndelsen af 1800-tallet, og efterfølgende blev alle bygninger på nær refektoriet revet ned. ${ }^{89}$

Franciskanerklostret blev stiftet i 1225, men vi ved ikke meget om dets grundlæggelse. Ved Reformationen havde brødrene et stort bygningskompleks på et meget centralt sted i byen (fig. 32). Franciskanerkirken var meget anderledes end ordenens andre klostre, og det har været foreslået, at kirken oprindelig var planlagt som en kirke for et kollegiatskapitel. ${ }^{90}$ Korpartiet er dendrodateret til 1304. ${ }^{11}$ Efter beslutningen om den nævnte "Kirchenordnung" blev klostret lukket i 1531, og de fleste af brødrene forlod det. Bygningerne blev senere brugt som et gymnasium (latinskole), som det stadig er (fig. 33). 


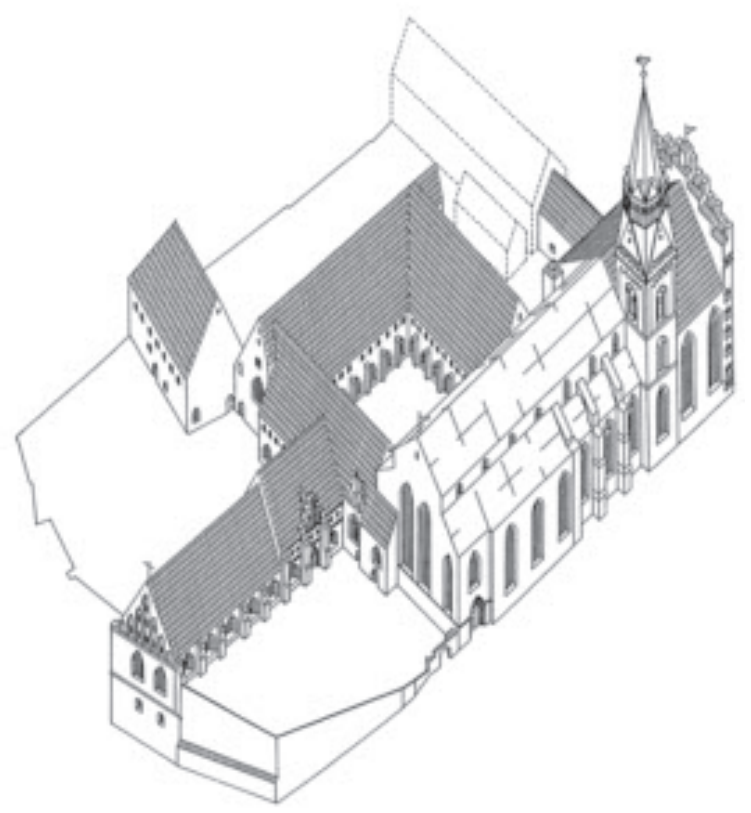

Fig. 34. Isometrisk tegning af Burgkloster i Lübeck set fra sydvest. Klosteranlægget består af bygninger fra forskellig tid. Ældst er nordfløjen, der i substansen er et genbrug af den store sal i Valdemar Sejrs borg fra før klostrets oprettelse. Den nu nedrevne kirke indeholdt bygningsdele fra 1200-, 1300- og 1400-tallet. Bygningen mod vest, der er opført på en betydelig opfyldning og underjordiske subkonstruktioner, er klostrets såkaldte "Skriftemålsbygning” fra midten af 1300-tallet. - Tegning: M. Gorski, efter Schneider 2014.

Isometric drawing of Burgkloster in Lübeck, seen from the southwest. The friary complex consists of buildings from different times. The north wing is earliest and essentially represents reuse of the great hall in Valdemar II's castle dating from before the abbey's construction. The now demolished church contained parts from the 13th, 14th and 15th centuries. The building to the west, which was built on a substantial fill layer and subterranean substructures, is the friary's so-called "confession house" from the mid-14th century.

Efter slaget ved Bornhøved i 1227 blev den danske borg i Lübeck omdannet til et dominikanerkloster som tak for sejren på Maria Magdalenas dag, og Valdemar Sejrs store sal blev genbrugt som nordfløj i klostret. ${ }^{92}$ Klostret blev indviet til Maria Magdalena som tak, fordi hun efter en bøn havde hjulpet til sejren ved Bornhøved, og klostret blev bevidst lagt på den sløjfede borgs plads for at forhindre et fremtidigt borganlæg her. Efter Reformationen blev klosterbygningerne genbrugt som hospital. Kirken blev revet ned i 1818 efter en sammenstyrtning, da den delvis var opført på den sløjfede voldgrav fra Valdemar Sejrs borg. Resten af komplekset er vel bevaret og huser i dag et museum (fig. 34-35). I forbindelse med ombygningen til museum i begyndelsen af det nye århundrede blev der udført omfattende arkæologiske undersøgelser, der har kastet lys over bygningshistorien..$^{93}$ 


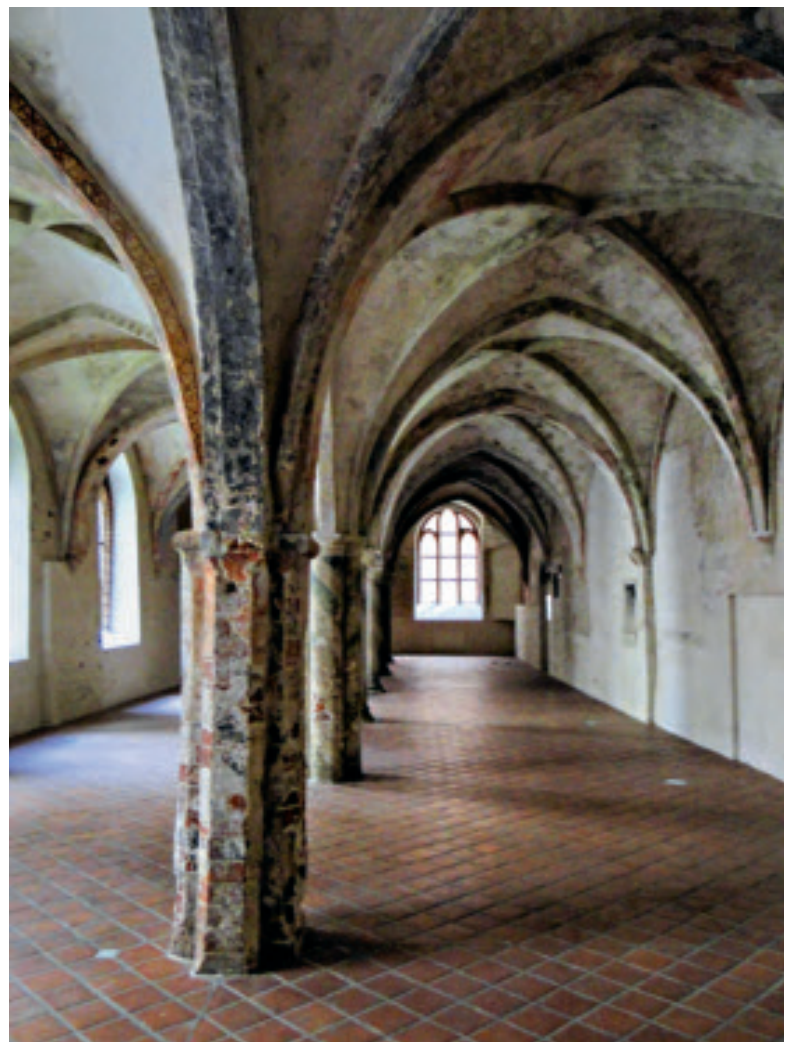

Fig. 35. Den store sal i Burgkloster. Selve bygningen $(10 \times 40 \mathrm{~m})$ er salen fra Valdemar Sejrs borg, mens overhvælvningen stammer fra klostertiden og er opført i flere omgange. - Foto: Wikimedia Commons 2012.

The large hall in Burgkloster. The actual building $(10 \times 40 \mathrm{~m})$ is the hall from Valdemar II's castle, while the vaulting is from the monastic period and was constructed in several stages.

Så sent som i 1502 blev et nyt kloster, Sankt Annen, stiftet af de mest velhavende borgere i byen. ${ }^{94}$ Årsagen hertil var et behov for anbringelser af enker og ugifte døtre. Nonneklostret af augustinerordenen blev lagt i den sydlige del af byen, men det var dog ikke uden problemer at finde plads i den tæet bebyggede by. ${ }^{95}$ Nonnerne forlod bygningerne i 1532, som derefter blev benyttet til forskellige formål. Efter en brand i kirken i 1843 blev komplekset ombygget til et kunstmuseum.

\section{Lüneburg}

Luthers tanker nåede sikkert til Lüneburg på samme tid som til Hamburg og Lübeck. ${ }^{96}$ I 1525 blev borgere, der læste Luthers skrifter, forjaget fra byen, men antallet af protestanter voksede alligevel i de følgende år. Den evangelisklutherske reformation i området blev gennemført af hertug Ernst af Braunzweig-Lüneburg ved udstedelsen af den såkaldte Artikelbuch i 1529, og byen Lüneburg blev pålagt at følge bestemmelserne. I det følgende år kom der mange sammenstød mellem katolikker og protestanter og herunder forstyrrelser af 
messer med salmesang fra de sidstnæunte. I 1529 blev franciskanerne den 28. august drevet ud af byen. I september 1531 accepterede byrådet i Lüneburg Reformationen med et nyt gejstligt system kaldet Schul- und Kircheordnung.

Lüneburg havde tre klostre inde i byen og et nonnekloster (Kloster Lüne) blot en kilometer uden for bymurene. Benediktinernes abbedi Sankt Michael var grundlagt i midten af 900 -tallet som det ældste kloster i Nordtyskland. ${ }^{97}$ I begyndelsen afviste munkene at slutte sig til Reformationen; men i 1532 konverterede deres prior til den lutherske dogmatik. Dette chokerede abbeden til døde, men resten af munkene fulgte prioren. Abbediet blev konverteret til et protestantisk kloster for mænd, der eksisterede frem til midten af 1600 -tallet. ${ }^{98}$ Senere fungerede det som skole for unge adelsmænd indtil 1850, mens bygningerne - bortset fra kirken og en enkelt fløj - blev genopbygget i 1700-tallet lidt længere væk fra det oprindelige sted..$^{99}$ En stor del af de nedrevne bygninger blev udgravet i 1978.

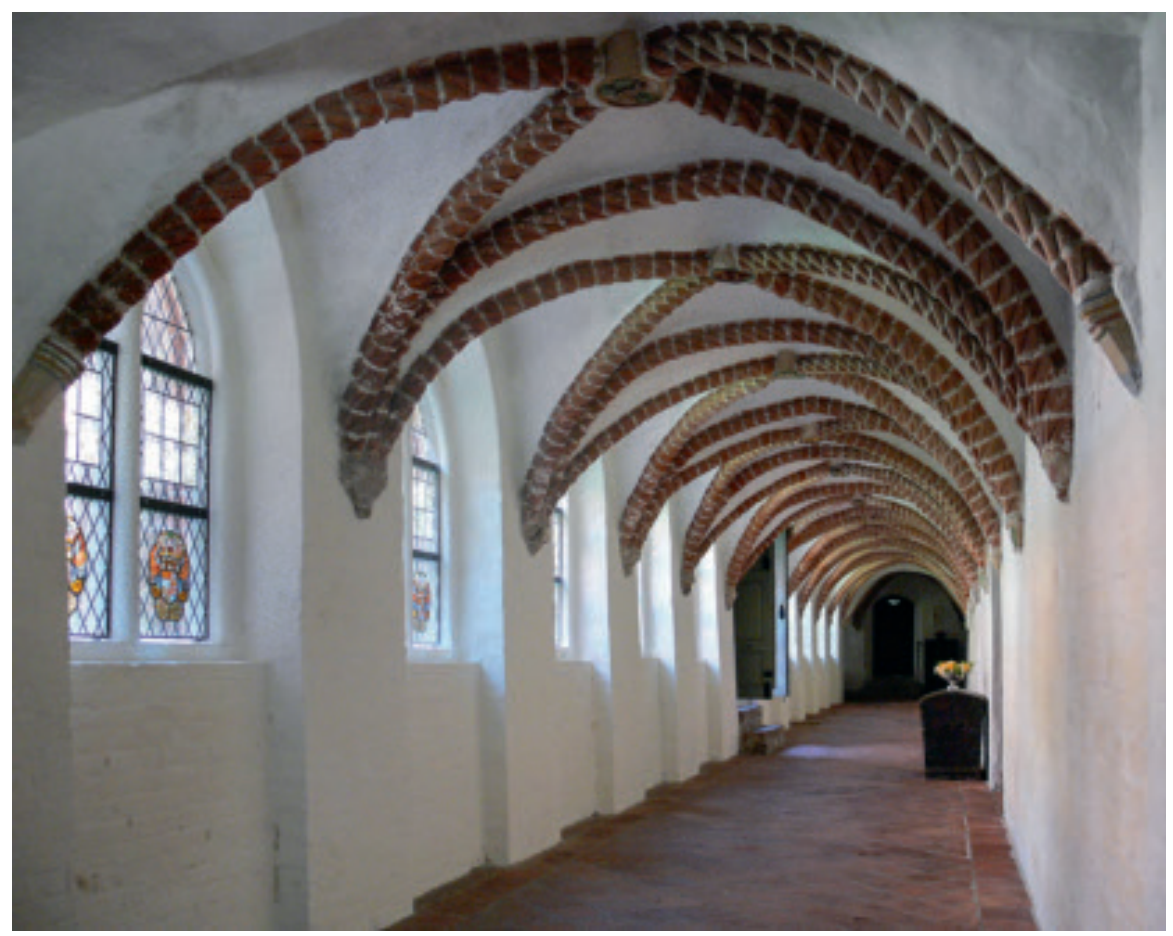

Fig. 36. Korsgangen i Kloster Lüne. I stedet for åbne arkader har korsgangen vinduer, hvori der er glasmalede våbenskjolde for adelige støtter. - Foto: Wikimedia Commons 2010.

The cloister in Kloster Lüne. Instead of open arcades, the cloister has windows in which there are the painted-glass coats of arms of its noble sponsors. 
Franciskanerklostret blev stiftet i midten af 1200-tallet i en udvidelse af byen, som senere blev en ret central del, ved siden af rådhuset. ${ }^{100}$ Bygningerne blev overtaget af byen i 1530. En del af klostret - måske refektoriet - er bevaret, mens resten er forsvundet gennem århundrederne, efter at klostret var omdannet til et bibliotek i $1535 .{ }^{101} \mathrm{I} 1382 \mathrm{blev}$ præmonstratensernes kloster i Heiligenthal overflyttet til Lüneburg by. Der blev skaffet plads ved opkøb af nogle grunde nær ved bymuren. Klostret blev lukket ved Reformationen i 1530, og kort efter begyndte nedrivningen af klostret - kirken som det sidste i 1820 .

Lidt uden for Lüneburg ligger benediktinernonneklostret Lüne, som blev grundlagt i $1140 .{ }^{102}$ Det forblev katolsk frem til 1562. I dag er det et evangelisk Damenstift oprettet i 1711. Både kirken og alle klosterbygninger er vel bevaret og i brug i dag. Kloster Lüne er blandt de bedst bevarede klostre for kvinder i Nordeuropa (fig. 36).

\section{Danzig}

Efter den Anden Fredsslutning i Thorn i 1460 hørte byen Danzig til kongeriget Polen, dog med en speciel politisk og økonomisk selvstændighed. Som den største by i det baltiske område modtog Danzig hele tiden nye ideer udefra. Nogle tanker kom fra unge mænd, som havde studeret i Wittenberg. ${ }^{103}$ Dominikaneren Jacob Knade begyndte at prædike på evangelisk vis i 1518, men fik forbud mod at gøre det af biskoppen. ${ }^{104}$ Senere i $1522 \mathrm{blev}$ han efterfulgt af Jakob Hegge (kaldet Finkelblock). I 1525 blev byen reformeret i luthersk forstand. De dominikanske og franciskanske tiggerbrødre blev udvist fra klostrene, og de, som ikke kunne rejse væk, blev anbragt i karmeliternes kloster, og bystyret ansatte fem prædikanter til at holde gudstjenester i kirkerne. ${ }^{105}$

På samme tid som de religiøse bevægelser opstod, var der store sociale og politiske problemer i Danzig. Krigen mellem Polen og Østpreussen i 1519-21 havde medført ødelæggelse af byens forstæder og ført til en overbefolkning med høje priser og høje skatter inden for murene. Det udløste en revolte og en ændring af byens råd. Dette skridt var ikke acceptabelt for den polske konge, som gav et ultimatum, at den tidligere borgmester skulle genindsættes. ${ }^{106}$ Konflikten endte med kong Sigismund I's angreb og indtagelse af byen. Herefter fulgte arrest, henrettelser, indsættelse af det gamle råd og en tilbagevenden til den katolske tro samt genhusning af tiggerbrødrene fra de forskellige klostre. Herefter varede det endnu 30 år, før den endelige Reformation blev ført igennem i Danzig i 1557.

Senmiddelalderens Danzig havde fire klostre - tre huse for tiggerklostre og et abbedi for Birgittinerne. Dominikanerne kom til byen så tidligt som 1227, mens franciskanerne først dukkede op i begyndelsen af 1400-tallet. ${ }^{107}$ Domi- 


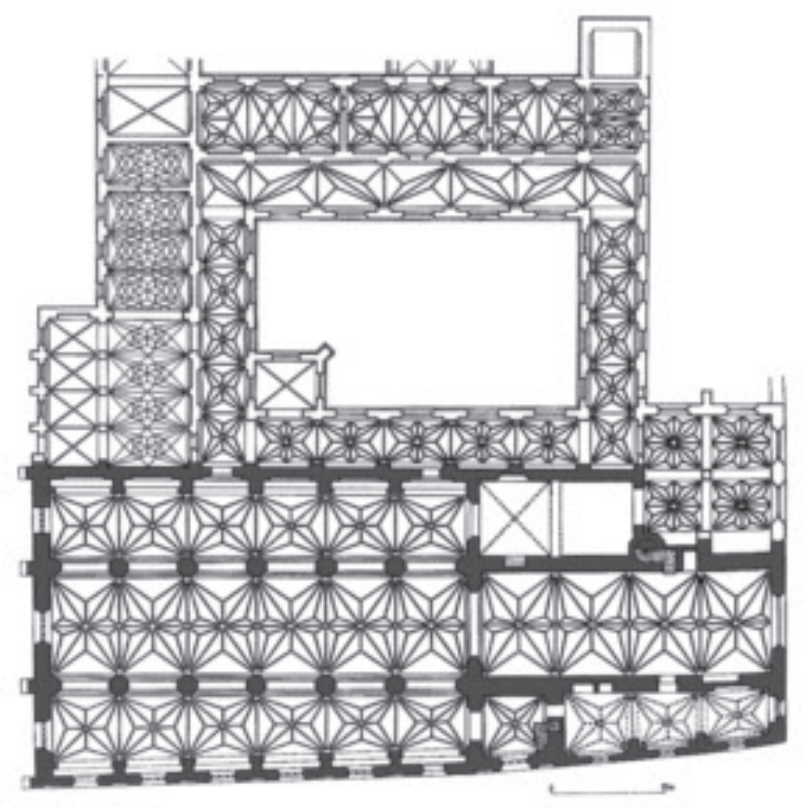

Fig. 37. Grundplan af dominikanerkirken i Danzig og klostergården nærmest kirken. Kirken blev opført i løbet af anden halvdel af 1300-tallet. Karakteristisk for området er der tale om en treskibet hallekirke med et langt etskibet kor. Som brugt i Danzig er hvert af skibene dækket af sit eget saddeltag. Brugen af stjerne- og nethvælv var helt dominerende i senmiddelalderen i Østpreussen og Danzig. - Efter Herrmann og von Winterfeld 2015.

Ground plan of the Dominican church in Danzig and the cloister garth closest to the church. The church was built in the second half of the 14th century. Characteristic of the area, it is a three-aisled hall church with a long, single-aisled choir/chancel. As is the norm in Danzig, each of the aisles has its own double-pitched roof. The use of star and net vaulting was totally dominant during the Late Middle Ages in East Prussia and Danzig.

nikanerne havde en stor treskibet kirke med et langt kor (fig. 37). På nordsiden var der mange fløje omkring en stor fratergård og to mindre. ${ }^{108}$ Efter den anden Reformation i 1557 forblev dominikanernes kirke katolsk og er stadig bevaret, mens klosterbygningerne forsvandt i 1700-tallet. Franciskanerklostret endte efter flere byggefaser med en stor kirke (indviet i 1514) ikke væsentlig anderledes end den ældre hos dominikanerne og med fløje omkring en stor fratergård ${ }^{109}$ Klosterbygningerne blev i 1558 omdannet til en skole, der blev et vigtigt protestantisk center for lærdom. Der var problemer omkring den fremtidige brug i begyndelsen af 1800-tallet, men den blev åbnet som et bymuseum i 1872 - i dag kaldet Nationalmuseet. ${ }^{110}$ Karmeliterne forblev katolske, indtil byen blev preussisk i 1810. Deres stort anlagte kirke fra slutningen af 1400-tallet er bevaret som sognekirke. Kirken var af samme type som dominikaner- og franciskanerkirken. Den ældste danske karmeliterstiftelse blev i øvrigt grundlagt i Landskrona i 1410 af brødre fra Danzig. 
Birgittinerklostret blev stiftet med pavelig godkendelse i $1394 .{ }^{111}$ Klostret var grundlagt inde i byen, så der var mindre plads end normalt for den type kloster. Traditionelt var klosterbygningerne for det kvindelige og det mandlige konvent placeret på hver sin side af kirken. Men i Danzig måtte de nødvendigvis placeres side om side på nordsiden (fig. 38). Det godsejende kloster blev ikke berørt af Reformationen i Danzig hverken i 1525 eller 1555. Det katolske konvent ophørte først i årene efter 1812. ${ }^{112}$

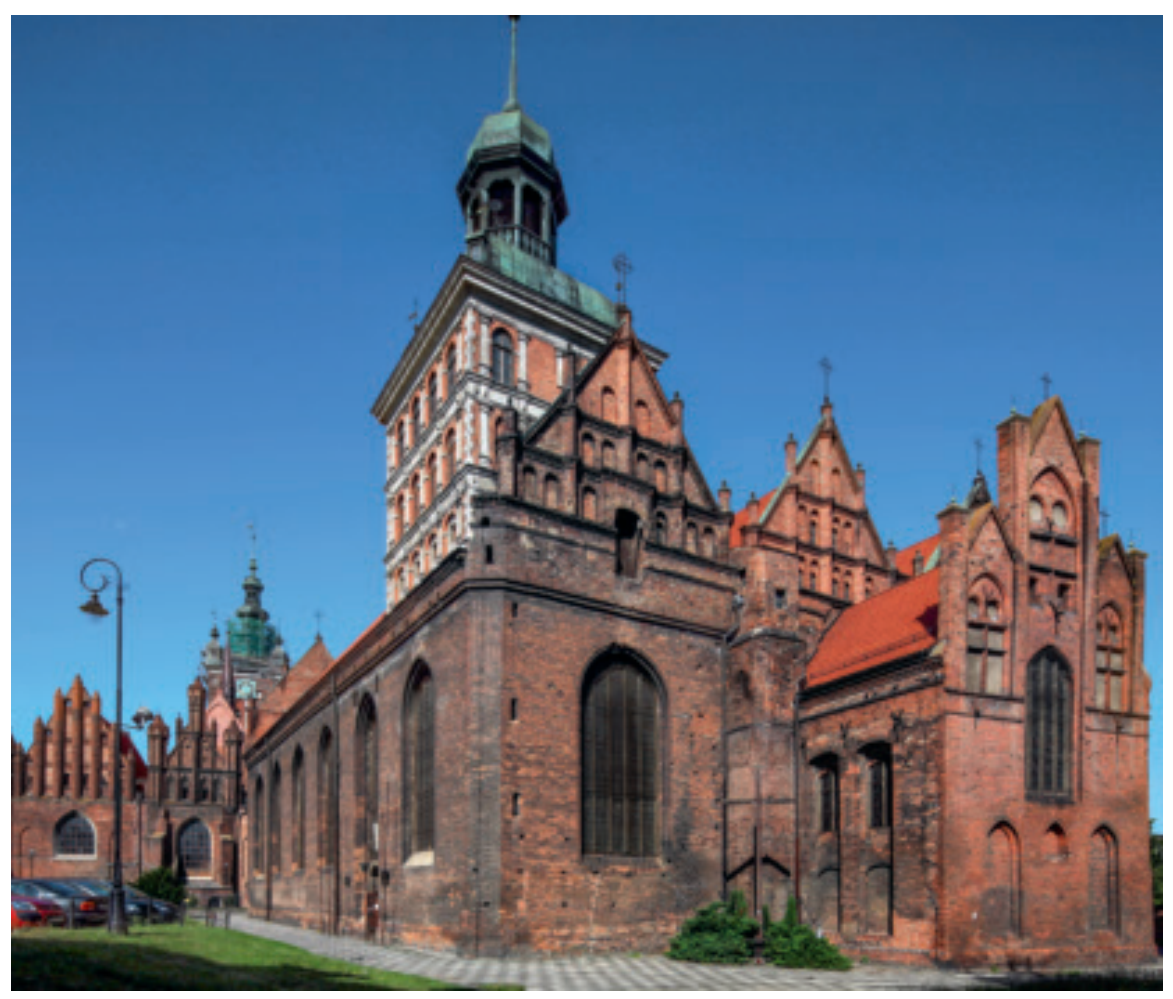

Fig. 38. Marienbrunn Klosterkirke i Danzig set fra sydøst. Som det var karakteristisk for mange af 1300-tallets nordtyske kirker, er stræbepillerne placeret indvendig, således at der er mulighed for en glat ydre væg. Udbygningen mod øst er det gamle Magdalena Kapel. Det var etableret for tidligere prostituerede, og her hvilede de jordiske rester af Den Hellige Birgitta undervejs fra Rom til Vadstena. I baggrunden ses Sankt Katharine Kirke, som havde afstået jord til birgittinerklostret. - Foto: Christofer Herrmann 2010.

Marienbrunn abbey in Danzig, seen from the southeast. It was characteristic of many of North Germany's 14th century churches that the buttresses were placed internally, making it possible to have a smooth outer wall. The extension to the east is the former Magdalena chapel. It was founded for former prostitutes, and here rested the mortal remains of St. Bridget en route from Rome to Vadstena. In the background St. Catherine's church which had given up land to the Bridgettine abbey. 


\section{Østpreussen}

Ved Den Anden Fredstraktat i Thorn (1460) blev Den Tyske Orden tvunget til af afstå Vestpreussen, byerne Danzig, Elbing og Marienburg sammen med stifterne Kulm og Ermeland til det polske kongerige. Og med hensyn til resten af Østpreusen måtte Den Tyske Orden aflægge lensed til kongen. Ordenens stormester, Albrecht markgreve af Brandenburg-Ansbach, som var udnævnt i 1511, prøvede forgæves at gøre den preussiske stat uafhængig og generobre Vestpreussen. ${ }^{113}$ Efter en ødelæggende krig blev han dog tvunget til at give op og aflægge lensed i 1525, men ved samme lejlighed blev han indsat som sekulær hertug i Østpreussen. Dette skridt blev accepteret af Den Tyske Orden i Preussen.

Gennem et længere ophold i Nürnberg i 1522-23 havde Albrecht truffet protestanterne der, og senere havde han talt med Luther i Wittenberg. Da han vendte tilbage fra dette møde, havde han to prædikanter med. Kort efter sin udnævnelse til hertug indkaldte han til et møde, en "Landtag", i december 1525, hvor han, de to biskopper og andre gejstlige presenterede en ny lutheransk kirkeordning, som blev modtaget. Så helt stilfærdigt blev Østpreussen i 1525 den første protestantiske stat og på dette tidspunkt $\mathrm{i}$ en lutheransk udformning. ${ }^{114}$ Året efter giftede hertug Albrecht sig med prinsesse Dorothea, der var datter af kong Frederik I af Danmark. På dette tidspunkt havde Frederik endnu ikke vist sin præference for den lutherske tro, så for ham var det et temmelig kontroversielt skridt.

Hertugdømmet Østpreusen husede kun to egentlige klostre - et franciskanerhus i byen Saalfeld og et nonnekloster i Königsberg. ${ }^{115}$ Den væsentligste årsag til de få klostre var naturligvis statens opbygning domineret af Den Tyske Orden, som ikke var interesseret i gejstlig konkurrence. Nonneklostret var oprindelig stiftet af cisterciensernonner i 1340, men blev senere benyttet af benediktinernonner. I 1531 blev det omdannet til et hospital. Franciskanerklostret fra 1480 blev nedlagt i 1534 af biskoppen ved reformeringen af Pomesanien og genbrugt som "Konsistorium" for den protestantiske stiftsadministration. Der er ikke bevaret spor efter de to klostre.

\section{Konklusion}

Med hensyn til klostrenes grundlæggelsestidspunkt og bygningshistoriske udvikling ses flere forskelle mellem Danmark og Nordtyskland, som skyldes den forskelligartede politiske og økonomiske udvikling i de to områder. Modsat Danmark, hvor klosterstiftelserne forløber gennem lange perioder i middelalderen, begynder de først i Nordtyskland efter den tyske (og danske) 
erobring/kolonisering af de slaviske områder. Til gengæld grundlægges der mange klostre gennem en forholdsvis kort periode begyndende i slutningen af 1100-tallet og fortsættende det næste århundrede igennem. Den store interesse for at stifte klostre i senmiddelalderen, som ses i Danmark kendes ikke tilsvarende syd for Østersøen.

Angående byggeriet er det i høj grad anden halvdel af 1200-tallet og en del af 1300-tallet, der er den store periode i Nordtyskland. Det er et tidsrum, hvor Danmark efter Valdemarstiden er præget af borgerkrige, strid mellem konge og kirke samt pantsætningerne til de holstenske grever. I 1300-tallet stiftedes der stort set ikke nye klostre i Danmark, og byggeriet på de eksisterende var beskedent. I Tyskland voksede hansestæderne vældigt frem, og der blev bygget i meget stor stil på både kirker og klostre.

Ved betragtningen af cistercienserklostrene ses, at nogle af de ældste i Nordtyskland har rod i den danske arkitekturtradition og er tidlige, mens der kommer andre med et lidt andet udgangspunkt og er opført på et senere tidspunkt. Karakteristisk for cistercienserklostrene i Danmark er som udgangspunkt en meget ambitiøs plan, som man de fleste steder ikke har kunnet realisere (fig. 39). Kirkerne bliver ikke bygget færdige, og det lukkede firfløjede anlæg med en fratergård omgivet af en grundmuret korsgang synes at være et senmiddelalderligt fænomen. Ved de kendte eksempler i Nordtyskland synes kirkerne at være fuldt udbygget forholdsvis tidligt, ligesom også klausurdelen almindeligvis bliver bygget færdig i højmiddelalderen.

For nonneklostrene i det nordtyske galder det som ved de danske, at der mangler systematisk forskning vedrørende klosteranlæggenes indretning. I Danmark fik ganske mange nonneklostre en ældre kirke som udgangspunkt. Dette synes ikke at være så udbredt syd for Østersøen, men da der heller ikke var så mange tidlige kirker, giver det sig selv. Som i Danmarks synes nonnerne at have opholdt sig på et hævet pulpitur i kirkens vestende. Og årsagen skal nok søges i, at kirken også var sognekirke eller åben for lægfolk på en eller anden måde. Til gengæld er der nogen uklarhed om, hvordan man forestiller sig, at nonnerne kom fra deres dormitorium til pulpituret. Hvor der i Danmark vel er en generel enighed om, at nonnernes dormitorium lå i vestfløjens andet stokværk med ret direkte adgang til pulpituret, ser man for det nordtyske område en del antagelser om, at nonneklostret har været struktureret som mandsklostrene med kapitelsal og dormitorium i østfløjen.

For tiggerklostrenes vedkommende er den væsentligste faktor til forskellighed nok specielt byernes størrelse. I Nordtyskland er tiggerklostrene i de mindre byer helt forsvundet, og der er ikke foretaget arkæologiske undersøgelser, der kan sige noget om klosteranlæggenes udformning. Kendskabet her 


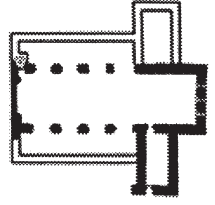

Holme

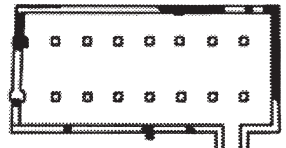

Tvis

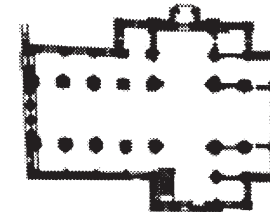

Løgum

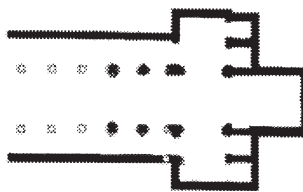

Herrevad

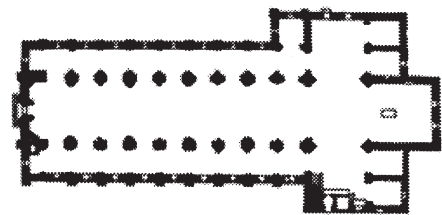

TE:

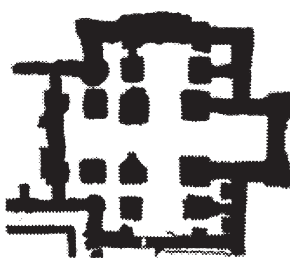

Sorø

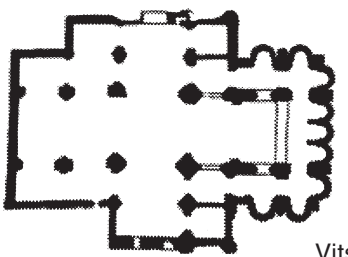

$\varnothing m$

Vitskøl

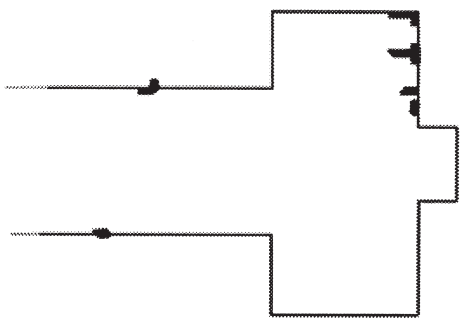

Esrum

$0 \quad 10$ 50
Fig. 39. Grundplaner af danske cistercienserklosterkirker. De fleste kirker fik ikke den tilsigtede længde. Blandt de afbildede planer er det lidt usikkert, om Esrum og Herrevad blev udbygget til fuld længde. Idealet har været en kirke af Fontenay-type, dvs. en treskibet basilika med tværskib, retkantet kor og retkantede kapeller ved tværskibets østside. Kirken i Vitskøl fik ret hurtigt en koromgang med ni apsider, mens munkene i Holme og Tvis med tiden opgav at opføre et tværskib. - Efter Callesen 2011.

Ground plans of Danish Cistercian abbey churches. Most churches never attained their intended length. Of the plans shown here, it is a little uncertain whether Esrum and Herrevad were extended to their full length. The ideal was a church of Fontenay type, i.e. a three-aisled basilica with transept, straight-edged chancel and straight-edged chapels at the east side of the transept. The church at Vitskøl very quickly acquired an ambulatory with nine apses, while the monks at Holme and Tvis eventually abandoned the idea of constructing a transept. 


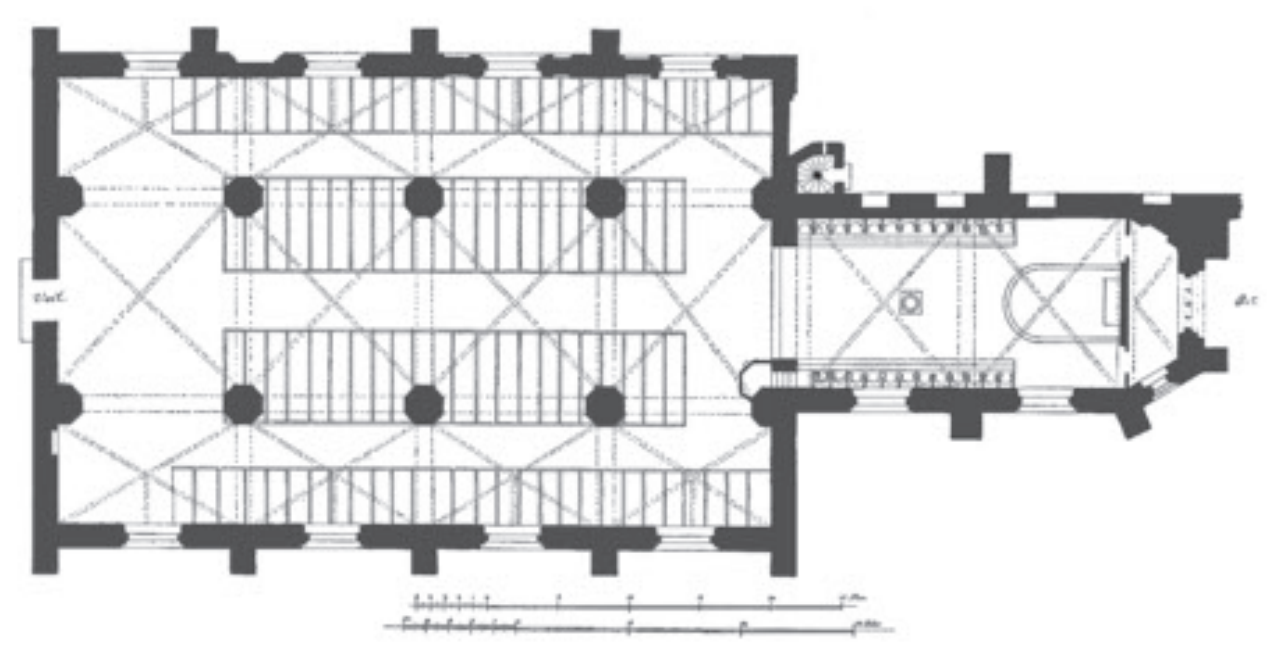

Fig. 40. Grundplan af klosterkirken i Fåborg. Kirken, der hører til den seneste del af middelalderen og derfor ikke blev helt færdig før Reformationen, har fået den karakteristiske planløsning, som kendetegner de betydeligt ældre tiggerklosterkirker i Nordtyskland. Dog er skibet ikke en hallekirke, men en pseudobasilika. - Efter Lorenzen 1912

Ground plan of the friary church at Faaborg. The church, which is from the final part of the Middle Ages and which was therefore not fully completed before the Reformation, has been given the distinctive layout that characterises the significantly earlier mendicant churches in northern Germany. The nave is, however, not a hall church but a pseudo basilica.

stammer således fra de store byer og fra klosteranlæggene, som de så ud på reformationstiden. Noget kunne tyde på, at i den første tid har ligheden med de danske klostre med en enskibet kirke og en usystematisk klostergård være større end senere. Kendskabet til de danske tiggerklostre stammer i vid udstrækning fra arkæologiske udgravninger og herunder også i de mindre byer. ${ }^{116}$

Specielt hansebyernes tiggerklostre fik en meget monumental udformning som treskibede hallekirker med smallere polygonalt afsluttede korpartier. De danske tiggerklostre var oprindeligt enskibede, men blev ved tilbygning gerne asymmetrisk toskibede. Den treskibede løsning ses i Danmark først ved det senmiddelalderlige byggeboom, hvor denne udformning optræeder ved Helligåndskirkerne i København, Randers og Fåborg (fig. 40). På denne tid blev der til gengæld ikke bygget ret meget nyt i de nærmeste områder syd for Østersøen. Derimod var der en vældig byggeaktivitet i eksempelvis Danzig og forskellige områder i Polen. ${ }^{117}$ Udviklingen foregik altså ikke parallelt, og der har nok ikke været så meget indflydelse på den danske arkitektur i senmiddelalderen som hævdet i gamle dage. ${ }^{118}$ 
Markant for de store tiggerklostre i hansebyerne er løsningen med to klostergårde og til dels korsgang også i den yderste gård. Enkelte steder ses også tilløb til to klostergårde i det danske materiale - dog ingen korsgang i gård nummer to.

Gennemgangen af afviklingen viser, at Reformationen er forløbet ret forskelligt fra sted til sted og med afvigende virkninger for klosterbygningerne. Ud fra en dansk baggrund viser det sig lidt overraskende, at munkene i et par klostre i Nordtyskland var blevet så grebet af de lutherske ideer, at de selv havde opgivet klosterlivet og lukket klostret.

Generelt ses det tydeligt af eksemplerne, at Reformationens skæbne i høj grad var afhængig af den magthavendes tro eller overbevisning, hvad enten denne var et byråd, hertugen eller kongen, og dernæst af den magt en sådan leder havde til at gennemføre sine ønsker. Dette var medvirkende til den meget afvigende udvikling for Reformationen blandt byer og fyrstendømmer i Nordtyskland og i kongeriget Danmark samt den hastighed, hvormed den gennemførtes.

Interessant nok bevægede den evangelisk-lutherske Reformation i Nordtyskland sig ikke fra vest til øst som almindeligvis antaget omkring spredningen af ideer, men nærmere den anden vej fra øst mod vest. I Østpreussen blev Reformationen indført uden problemer i 1525 af den nye hertug, Den Tyske Orden, to biskopper og andre gejstlige i fællesskab.

Danzig blev reformeret i den lutherske version i 1525, men på grund af ændringerne i byrådet fik den polske konge mulighed for at blande sig og tilbageføre ændringerne. Den religiøse reformering i Danzig blev derfor forsinket i 30 år.

Reformationen i Stralsund blev temmelig voldelig i 1525, men endte efter nogle få dage i en almindelig enighed om en antagelse af Luthers lære. Det foregik i øvrigt mange år før Reformationen i resten af hertugdømmet Pommern.

I Hamburg besluttede borgerne og byrådet efter en disputation mellem de lærde at antage den lutherske tro i 1528. Lidt på samme ukomplicerede vis foregik det i Rostock i 1531 og ligeledes i Wismar i 1532. I andre byer som Lübeck og Lüneburg var der store meningsforskelle mellem byrådet og de almindelige borgere, således at processen tog lang tid. Byerne overgik dog til protestantismen i 1530-31.

Den samlede gennemførelse af Reformationen i hele Pommern blev besluttet på et møde, et såkaldt "Landtag", i Treptow i 1534. Det foregik lidt tidligere end i Danmark og i øvrigt uden støtte fra adelen. I Mecklenburg med et delt styre var der en lang periode med en rodet overgang, hvor begge retninger eksisterede samtidigt side om side, og først i 1549 blev hele Mecklenburg til et protestantisk land med tilslutning fra alle grupper. 
Den politiske situation i Danmark på reformationstiden var tydeligvis forskellig fra forholdene i Mecklenburg og Pommern. Magtudøvelsen var på visse områder mere centraliseret i Danmark, men på den anden side var kongen meget afhængig af rigsrådet, hvor der var en stor gruppe katolske prælater. Uddrivelsen af tiggermunkene fra deres klostre blev helt sikkert accepteret af kong Frederik I, og blev ført igennem i løbet af kort tid (1528-32), men kun i få byer foregik der en egentlig kirkelig reformation i den forbindelse, og den lovlige undertrykkelse af tiggerordenerne kom først i 1537, efter at kong Christian III havde vundet borgerkrigen. Så i virkeligheden var der en ret lang periode, hvor situationen ikke var afklaret, og Reformationen i Danmark blev en langtrukket affære og undertiden temmelig voldelig - og det endda uden at medregne borgerkrigen, Grevens Fejde. Den egentlig ændring af kirkelivet kom betydeligt senere end i de fleste af nabostaterne i Nordtyskland. Hovedparten af tiggerklostrenes bygninger blev tilbudt byerne, men det meste forsvandt efter kortere eller længere tid.

I Mecklenburg-Vorpommern blev mange tiggerklostre hurtigt lukket ved Reformationen, som ganske vist foregik på forskellige tidspunkter i de forskellige områder. Kun i få tilfælde hører vi i øvrigt om samme brutale uddrivning som i Danmark. I de store byer blev klostrene genbrugt som skoler og hospitaler. Desværre forsvandt der nogle klosterbygninger i Nordtyskland i anden halvdel af 1800-tallet på grund af byudvikling. Deres planløsning og til dels udseende er dog kendt. Generelt er klosterbygningerne dog bedre bevaret eller bedre kendt her end i de danske byer. Derimod er byklostrene i Hinterpommern gået tabt i tidens løb - bl.a. som følge af krige som Trediveårskrigen og Anden Verdenskrig.

Vedrørende de godsejende herreklostre på landet er der kun få velbevarede klosteranlæg i Danmark eller Nordtyskland. Takket være udgravninger og andre undersøgelser kan vi alligevel supplere mange klosterkirker og -bygninger. Det ser dog ud til, at på grund af Reformationens forskelligartede gennemførelse er nonneklostrene bedre bevarede i Nordtyskland, hvor mange fortsatte som "Damenstift", mens der til gengæld er mere tilbage fra de mandlige klostre i Danmark - om end i ombygget tilstand.

Siden murens fald har der i det gamle Østtyskland været foretaget et utal af arkæologiske udgravninger og bygningsarkæologiske undersøgelser i middelalderlige klostre, som vi i Danmark kun kan være misundelige på. Det hænger naturligvis sammen med, at der var et stort behov for at sætte bygningerne $\mathrm{i}$ stand og forske i de kirkelige monumenter. Samtidig med istandsættelsen er mange klostre også gjort mere tilgængelige for offentligheden. I Danmark er det nærmest gået den modsatte vej. ${ }^{119}$ 
Når man ser på den fysiske situation på klosteranlæggene i MecklenburgVorpommern og det oprindelige middelalderlige Danmark, er der næsten 500 år efter Reformationen naturligt nok ikke mange totalt bevarede middelalderlige klostre, og i Hinterpommern er der endnu færre. Samlet og med udsyn over grænserne har vi alligevel en meget stor viden om de middelalderlige klostre i Nordeuropa - og antallet taget i betragtning noget bedre end i mange katolske områder med moderniseringer i baroktiden.

\section{NOTER}

1. For det danske materiale gives en oversigt i Krongaard Kristensen 2017.

2. Da de danske klostre skønnes bedre bekendte af læserne end de tyske, vil disse sidste i højere grad blive illustreret,

3. Krongaard Kristensen 2013, s. 82.

4. Krongaard Kristensen 2013, s. 100.

5. Lindbæk 1914, s. 55-56; Krongaard Kristensen 2013, s. 72.

6. Krongaard Kristensen 2013, s. 433.

7. På grund af den nuværende politiske opdeling af Pommern mellem Tyskland og Polen er det undertiden nemmest at arbejde med de to dele af Pommern separat.

8. Ebert \& Grundner 2009, s. 12-20.

9. Da der også var et par nonneklostre i byerne, var andelen af nonneklostre betydeligt højere i Mecklenburg-Vorpommern end i Danmark, hvor andelen kun var på $20 \%$.

10. Möller 2003, s. 95-96.

11. Ebert \& Grundner 2009, s. 88.

12. Ebert \& Grundner 2009, s. 41.

13. Ebert \& Grundner 2009, s. 60.

14. Ebert \& Grundner 2009, s. 92.

15. Rügenwalde, se Hoogewg 1925, bd. 2, s. 369-371. Stettin, se Gwiazdowska 2003, s. 212-213.

16. Krongaard Kristensen 2018.

17. Krongaard Kristensen 2013, s. 100-103.

18. Kratzke 2004, s. 107-109.

19. Ebert \& Grundner 2009, s. 163 \& 167.

20. Ebert \& Grundner 2009, s. $101 \& 97$.

21. Ebert \& Grundner 2009, s. 84.

22. Krøniken om Gaabrødrenes fordrivelse fra deres klostre i Danmark; ScrMin II, s. 325-368.

23. Rübner Jørgensen 1979, s. 37.

24. Krongaard Kristensen 2016, s. 19-20.

25. FrIReg, s. $271-273 \& 336$.

26. Hoogeweg 1924, Bd. 1, s. 68-70; Kirchenordnung, s. 18-20.

27. Leder 1985, s. 12-17. 
28. Hoogeweg 1924, Bd. 1, s. 70-71.

29. Buske 1985 , s. $75 \& 78$.

30. Buske 1985, s. 75.

31. Buske 1985, s. 78-80.

32. Buske 1985, s. 72.

33. Ewe 2001, s. 107-109.

34. Hoffmann 2003, s. 105.

35. Ebert \& Grundner 2009, s. 96-97; Hoffmann 2003, s. 107-111.

36. Möller 2014, s. 313-316. Tagværket over skibet regnes for det ældste monumentale tag over en hallekirke i Tyskland.

37. Hoffmann 2003, s. 108.

38. Möller 2014, s. 323.

39. Buske 1985, s. 106-109.

40. Buske 1985, s. 110-115; Schilling 2014, s. 52-53.

41. Leder 1985, s. 12-29.

42. Buske 1985, s. 111-113.

43. Kirchenordnung 1985, s. 112. Vedrørende Bergen: Wichert 2005, s. 8-16; Rother \& Wagner 2005, s. 69-80. Kolberg: Hoogeweg 1924, Bd. 1, s. 372-374. Marienfließ: Hoogeweg 1925, Bd. 2, s. 118; Groeneveld 1999, s. 98-100. Stolp: Hoogeweg 1925, Bd. 2, s. 640-641. Verchen: Hoogeweg 1925, Bd. 2, s. 782; Ebert \& Grundner 2009, s. 104.

44. Buske 1985, s. 60.

45. Hoogeweg 1924-25, passim.

46. Buske 1985, s. 115.

47. Hoogeweg 1925, Bd. 2, s. 497-501; Kloer 1929, s. 2-6; Ebert \& Grundner 2009, s. 58.

48. Hoogeweg 1925, Bd. 2, s. 277-278; Gralak 1999, s. 134-136.

49. Hoogeweg 1925, Bd. 2, s. 183-189; Ebert \& Grundner 2009, s. 53-54.

50. Wolgast 2004, s. 145-147.

51. Wolgast 2004, s. 149-150.

52. Ebert \& Grundner 2009, s. 88-89; Mulsow 2014, s. 373-375.

53. Kunst-Denkmäler Bd. I, s. 240-242; Ebert \& Grundner 2009, s. 88-89.

54. Ebert \& Grundner 2009, s. 84-88; Mulsow 2014, s. 367-372. Om udgravningerne i tiggerklosterne i Rostock, se: Mulsow 2014, s. 375-379.

55. Untermann 2010.

56. Wolgast 2004, s. 168; Ebert \& Grundner 2009, s. 83-84.

57. Mulsow 2014, s. 376-379.

58. Wolgast 2004, s. 150-151.

59. Gralow 2014, s. 232-235; Untermann 2010, s. 34-35.

60. Ebert \& Grundner 2009, s. 58; Gralow 2014, s. 229-240.

61. Wolgast 2004, s. 150-151.

62. Wolgast 2004, s. 153. 
63. Wolgast 2004, s. 160-163.

64. Wolgast 2004, s. 165.

65. Wolgast 2004, s. 165.

66. Ebert \& Grundner 2009, s. 90-92.

67. Ebert \& Grundner 2009, s. 135.

68. Wolgast 2004, s. 168.

69. Ebert \& Grundner 2009, s. 27.

70. Wolgast 2004, s. 169.

71. Schöfbeck, Schöfbeck \& Witt 2009; Schöfbeck 2014, s. 71-74.

72. Ebert \& Grundner 2009, s. 26-27.

73. Ebert \& Grundner 2009, s. 26-27 \& 44.

74. Ebert \& Grundner 2009, s. 14 \& 64-66.

75. Kratzke 2004, s. 342 \& 391-392.

76. Ebert \& Grundner 2009, s. 53.

77. Schöfbeck 2014, s. 90-95. En ny bygningshistorie på grundlag af Schöfbeck dendrokronologiske datering af tagværket til 1297 er fremlagt i Kayser og Rehm 2013.

78. Kolderup-Rosenvinge 1824 IV, p. s. 157-171.

79. Krongaard Kristensen 2013, s. 435-439.

80. Kirkeordinansen 1537/39. Lovgivningen udkom på latin i 1537 og på dansk i 1539. Forbuddet omtales i det dansksprogede udkast til kirkeordinans: Tyggebrödre muncke skulle her effther vdj thette riige icke vppeholdis, the skulle icke heller trygle, icke predicke $\varepsilon c$. Ligeledes i den dansksprogede udgave af 1539 udtrykkes forbuddet mod tiggermunke tydeligt: Ingen Tiggemuncke skulle wdi wore Riiger effter denne dag ophol= dis, Huercken skulle de tigge eller predicke, eller hore skriftemaal.

81. Rübner Jørgensen 2001.

82. Krongaard Kristensen 2013, s. 413; Krongaard Kristensen 2017, s. 19-20.

83. Krongaard Kristensen 2013, s. 436-438.

84. Ved nogle klostre er der i tidens løb foretaget arkæologiske undersøgelser, Biermann 2018, s. 329-338.

85. Först 2014.

86. Således tolket af Untermann 2010a.

87. Om Reformationen i Lübeck, se Hauschild 1981, s. 165-193.

88. Gläser 2003, s. 57; Schneider 2014, s. 407-413.

89. Schneider 2014, s. 413

90. Untermann 2010b.

91. Schöfbeck 2014, s. 110-11.

92. Mührenberg 2003, s. 31; Schneider 2014, s. 413-422.

93. Radis 2003.

94. Hauschild 1981, s. 133-135.

95. Schneider 2014, s. 423-424.

96. Om Reformationen i Lüneburg, se Plath 2016.

97. Ring 2014, s. 385-390. 
98. Plath 2016, s. 4.

99. Ring 2014, s. 389.

100. Ring 2003, s. 16 \& fig. 1.

101. Ring 2014, s. 392-394.

102. Ring 2014, s. 395-398.

103. I det mindste 13 af de studerende i Wittenberg i perioden 1500-1525 kom fra byen Danzig, Bartel 1967, s. 37.

104. Bartel 1967, s. 37.

105. Frandsen 2002, s. 84.

106. Frandsen 2002, s. 85-86.

107. Kowalski 2003, s. 239; Massowa 2003, s. 225.

108. Paner 2014, s. 449-457.

109. Massowa 2003.

110. Massowa 2003, s. 228.

111. Berthelson 1947, s. 362-406.

112. Berthelson 1947, s. 396.

113. Om Albrecht og Reformationen i Preussen, se Lohmeyer 1875.

114. Senere blev det mere broget, især ved ansættelsen af Andreas Osiander, hvis teologi afveg lidt fra Luthers, som professor ved universitet i Königsberg i 1549.

115. Herrmann 2007, s. 264-265.

116. Larsen 2018, s. 15-20.

117. Om klostrene i Danzig, se Herrmann \& von Winterfeld 2015, s. 230-240.

118. Becket 1927, s. 20.

119. I eksempelvis karmeliterklostret i Helsingør, der ofte omtales som Nordens bedst bevarede klosteranlæg, breder stiftsadministrationen sig over en stor del af de historiske rum, som om der er permanent mangel på kontorlokaler i Helsingør.

\section{LITTERATUR}

Bartel, Oskar 1967: Martin Luther und Polen. I: Vierhundertfünfzig Jahre lutherrische Reformation 1517-1967. Festschrift für Franz Lau zum 60. Geburtstag. Göttingen, s. 27-42.

Beckett, Francis 1927: Danmarks Kunst II. Gotikken. København.

Berthelson, Bertil 1947: Studier i Birgittinerordenens byggnadsskick I. Anlägningsplanen och dess tillämpning. Stockholm.

Biermann, Felix 2018: Untergegangene Klöster und Stifte in Pommern: Stand und Perspektiven ihrer archäologischen Erforschung. I: Nils Jörn \& Haik Thomas Podrada (Hrsg.): Die historische Kommission für Pommern 1911-2011. Bilanz und Ausblick. Köln/ Weimar, s. 317-348.

Buske, Norbert 1985: Die Reformation im Herzogtum Pommern. I: Hans-Günter Leder \& Norbert Buske: Reform und Ordnung aus dem Wort. Johannes Bugenhagen und die Reformation im Herzogtum Pommern. Berlin, s. 46-133.

Ebert, Martin \& Thomas Grundner 2009: Klöster in Mecklenburg-Vorpommern. Rostock.

Ewe, Herbert 2001: St. Nikolai und die Reformation. I: Paul-Ferdi Lange (Hrsg.): Wenn Räume singen. St. Nicolai zu Stralsund. Stralsund, s. 105-109. 
Frandsen, Karl Erik 2002: Fine danske damer i Gdansk. En episode fra reformationstiden. I: Charlotte Appel, Peter Henningsen \& Nils Hybel (red.): Mentalitet $\&$ Historie. Om fortidige forestillingsverdener. Ebeltoft, s. 79-94.

FrIReg: Kong Frederik den Førstes danske Registranter, udg. ved Kr. Erslev og W. Mollerup. Kjøbenhavn 1879.

Först, Elke 2014: Hamburgs verschwundene Klöster im Spiegel der historischen und archäologischen ûberlieferung. Lübecker Kolloquium zur Stadtarchäeologie im Hanseraum IX (Die Klöster). Lübeck, s. 181-198.

Gläser, Manfred 2003: Das Lübecker St. Johannis-Kloster vom 12. bis zum 16. Jahrhundert. Stralsunder Beiträge zur Archäologie, Geschichte, Kunst und Volkskunde, Band IV (Klöster und monastische Kultur in Hansestädten), s. 57-68.

Gralack, Justyna 1999: Das Kloster Kolbatz. I: Ulrich Knefelkamp und Wolfgang F. Redding (Hrsg.): Klöster und Landschaften. Zisterzienser westlich und östlich der Oder. Frankfurt an der Oder 1999, s. 131-137.

Gralow, Rita 2014: Klösterliche Einrichtungen im Wismar im archäologischen Kontext. Lübecker Kolloquium zur Stadtarchäeologie im Hanseraum IX, 2014, (Die Klöster), s. 229-244.

Groeneveld, Melanie 1999: Das Zisterzienserkloster Marienfliess. I: Ulrich Knefelkamp und Wolfgang F. Redding (Hrsg.): Klöster und Landschaften. Zisterzienser westlich und östlich der Oder. Frankfurt an der Oder, s. 98-100.

Gwiazdowska, Ewa 2003: Darstellungen der Klosteranlagen in der Ikonographie Stettins vom 16. bis zum 19. Jahrhundert. Stralsunder Beiträge zur Archäologie, Geschichte, Kunst und Volkskunde, Band IV (Klöster und monastische Kultur in Hansestädten), s. 205-224.

Hauschild, Wolf-Dieter 1981: Kirchengeschichte Lübecks - Christentum und Bürgertum in neun Jahrhunderten. Lübeck.

Hermann, Christofer 2007: Mittelalterliche Architektur im Preussenland. Petersberg.

Hermann, Christofer \& Dethard von Winterfeld 2015: Mittelalterliche Architektur in Polen. Romanische und gotische Baukunst zwischen Oder und Weichsel. Petersberg.

Hoffmann, Claudia 2003: Stralsund und die Reformation - Auswirkungen af die Klöster der stadt. Stralsunder Beiträge zur Archäologie, Geschichte, Kunst und Volkskunde, Band IV (Klöster und monastische Kultur in Hansestädten), s. 103-120.

Hoogeweg, Hermann 1924-25: Die Stifter und Klöster der Provinz Pommern, Bd. 1-2. Stettin.

Kayser, Christian \& Jörg Rehm 2013: Der Bau der Klosterkirche von Doberan. Neu Untersuchungen zur Baugeschichte. (Spiritualität und Baukunst. Leben und Wirken der Zisterzienser im Kloster Doberan). Convent. Beiträge zur Geschichte des Klosterwesens in Mecklenburg und Vorpommern, Band 5, s. 110-132.

Kirchenordnung: Die Pommersche Kirchenordnung von Johannes Bugenhagen 1535. Text mit übersetzung, Erläuterungen und Einleitung. (Hrsg. im Auftrag der Evangelischen Landeskirche Greifswald von Norbert Buske). Berlin 1985.

Kirkeordinansen 1537/39: Kirkeordinansen 1537/39: Det danske Udkast til Kirkeordinansen (1537). Ordinatio Ecclesiastica Regnorum Daniae et Norwegiae et Ducatuum Sleswicensis Holtsatiae etc. (1537). Den Danske Kirkeordinans (1539) ved Martin Schwarz Lausten. København 1989.

Kowalski, Krzysztof Maciej 2003: Die epigraphischen Denkmäler in Klosterkirchen Danzigs des Mittelalters und der Neuzeit. Stralsunder Beiträge zur Archäologie, 
Geschichte, Kunst und Volkskunde, Band IV (Klöster und monastische Kultur in Hansestädten), s. 239-252.

Kloer, Hans 1929: Das Zisterzienserkloster Eldena in Pommern. Berlin.

Kolderup-Rosenvinge, J.L.A. 1824: Gamle danske Love IV. København.

Kornerup, J. 1881: Om Esrum Klosters Forbindelser med Venden og de Architektoniske Spor deraf. Aarbøger for nordisk Oldkyndighed og Historie, s. 1-37.

Kratzke, Christine 2004: Das Zisterzienserkloster Dargun in Mecklenburg-Vorpommern. Petersberg.

Krongaard Kristensen, Hans 2013: Klostre i det middelalderlige Danmark. Højbjerg.

Krongaard Kristensen, Hans 2016: Franciskanerklostret i Horsens. Højbjerg.

Krongaard Kristensen, Hans 2017a: Tvilum Kloster. Højbjerg.

Krongaard Kristensen, Hans 2017b: De danske klostre og reformationen. I: Ole Høiris og Per Ingesman (red.): Reformationen. 1500-tallets kulturrevolution. Danmark. Aarhus, s. 223-245.

Krøniken om Graabrødrenes fordrivelse fra deres klostre i Danmark 1967 (oversat af Henning Heilesen). København.

Kunst-Denkmäler: Die Kunst- und Geschichts-Denkmäler des Grossherzogthums Mecklenburg-Schwerin Band I-V (Berab. von Friedrich Schlie). Schwerin 1896-.

Larsen, Morten 2018: Danmarks middelalderlige tiggerklostre. Franciskanernes og dominikanernes bygningskultur. Højbjerg.

Leder, Hans-Günter 1985: Leben und Werk des Reformators Johannes Bugenhagen. I: Hans-Günter Leder \& Norbert Buske (eds.): Reform und Ordnung aus dem Wort. Johannes Bugenhagen und die Reformation im Herzogtum Pommern. Berlin, s. 9-45.

Lindbæk, Johs.,1914: De danske Franciskanerklostre. København.

Lohmeyer, K. 1875: 'Albrecht'. I: Allgemeine Deutscher Biographie. Berlin, s. 293-310.

Lorenzen, Vilh. 1912: De danske Helligaandsklostres Bygningshistorie (= De danske Klostres Bygningshistorie I), København.

Massowa, Zbigniew 2003: Das Franziskanerkloster und Nationalmuseum zu Danzig. Stralsunder Beiträge zur Archäologie, Geschichte, Kunst und Volkskunde Band IV (Klöster und monastische Kultur in Hansestädten), s. 225-238.

Mulsow, Ralf 2014: Klöster und andere monastische Einrichtungen in Rostock. Lübecker Kolloquium zur Stadtarchäeologie im Hanseraum IX, (Die Klöster), s. 309-331.

Mührenberg, Doris 2003: ... und alsbald auf die wüste Stätte ein herrliches Kloster zu bauen ... oder wie aus Lübecker Burg das Marien-Magdalenen-Kloster wurde. Stralsunder Beiträge zur Archäologie, Geschichte, Kunst und Volkskunde, Band IV (Klöster und monastische Kultur in Hansestädten), s. 27-40.

Möller, Gunnar 2003: Zur Topographie der Klosteranlagen in der Hansestadt Stralsund. Stralsunder Beiträge zur Archäologie, Geschichte, Kunst und Volkskunde, Band IV (Klöster und monastische Kultur in Hansestädten), s. 91-102.

Möller, Gunnar 2014: “... hat auch drey schone closter, viele capellen und hospital ...! Klöster, Zisterzienserhöfe und Beginen in der einstigen Hansestadt Stralsund, Lübecker Kolloquium zur Stadtarchäeologie im Hanseraum IX, (Die Klöster), s. 367-384.

Paner, Henryk 2014: Medieval Monasteries in Gdansk. Lübecker Kolloquium zur Stadtarchäeologie im Hanseraum IX, (Die Klöster), s. 449-460.

Plath, Uwe 2016: Chronik der Reformation in Lüneburg, www.spuren-suche-zukunft. de/...Dr-Uwe-Plath/Chronik

Radis, Ursula 2003: Ergebnisse der neuesten archäeologischen Untersuchungen auf 
dem Gelände des ehemaligen Dominikanerkloster zu Lübeck. Stralsunder Beiträge zur Archäologie, Geschichte, Kunst und Volkskunde, Band IV (Klöster und monastische Kultur in Hansestädten), s. 41-56.

Ring, Edgar 2003: Klöster und Klosterhöfe in Lüneburg. Stralsunder Beiträge zur Archäologie, Geschichte, Kunst und Volkskunde, Band IV (Klöster und monastische Kultur in Hansestädten), s. 15-25.

Ring, Edgar 2014: Klöster in Lüneburg - historische, bauhistorische und archäologische forschungen. Lübecker Kolloquium zur Stadtarchäeologie im Hanseraum IX, 2014, (Die Klöster) s. 385-399.

Rother, Hannes \& Jörn Wagner 2005: Der Klostergelände und seine Gestaltung von den Anfängen bis zur Gegenwart. I: Annette Brandes \& Werner Willmes (Hrsg.): Der Klosterhof und die Kirche St. Marien in Bergen auf Rügen. Bergen, s. 64-87.

Rübner Jørgensen, Kaare 2010: Old wine, new wine - Maribo Abbey after the Reformation. Birgittiana 12, s. 121-155.

Rübner Jørgensen, Kaare 1979: De Hvide Brødre i Helsingør. Helsingør Bymuseum Årbog, s. 5-63.

Schneider, Manfred 2014: Archäologie in monastischen Einrichtungen der Hansestadt Lübeck. Lübecker Kolloquium zur Stadtarchäeologie im Hanseraum IX, (Die Klöster) s. 401-428.

Schilling, Johannes 2014: Gespannte Aufmerksamkeit für Luthers Theologie. Die Reformation im Herzogtum Pommern. I: Daniel Mourkojannis (Hrsg.): Orte der Reformation. Mecklenburg und Pommern. Leipzig s. 50-53.

Schäfer, Heiko 1993: Das archäologische und bauhistorische Forschungsprojekt Katharinenkloster zu Rostock. Schriften des Kulturhistorischen Museums in Rostock 1, (= Archäologie des Mittelaters und Bauforschung im Hanseraum), s. 347-352.

Schöfbeck, Tilo 2014: Mittelalterliche Kirchen zwischen Trave und Peene. Studien zur Entwicklung einer norddeutschen Architekturlandschaft. Berlin.

Schöfbeck, Sabine, Tilo Schöfbeck \& Detlef Witt 2009: Kloster Sonnenkamp in Neukloster. Petersberg.

ScrMin: Scriptores minores historic Danica medii ævi I-II, udg. ved M.Cl. Gertz. København 1917-20.

Untermann, Matthias 2010a: Öffentlichkeit und Klausur. Beobachtungen zur franciskanischen Klosterbaukundt in der Provins Saxonia. I: Dirk Schumann (Hrsg.): Brandenburgische Franziskanerklöster und norddeutsche Bettelordensbauten. Architektur - Kunst - Denkmalpflege. Berlin.

Untermann, Matthias 2010b: Wurde die Lübecker Katharinenkirche als Franziskanerkirche gebaut? Zeitschrift für Lübeckische Geschichte. Band 90.

Wichert, Sven 2005: Zur Geschichte des Klosters. I: Annette Brandes \& Werner Willmes (Hrsg.): Der Klosterhof und die Kirche St. Marien in Bergen auf Rügen. Bergen, s. 4-16.

Wislocki, Marcin 1999: Kolbatz und seine Filiationen. Ein kunstgeschichtliche Überblick. I: Ulrich Knefelkamp und Wolfgang F. Redding (Hrsg.): Klöster und Landschaften. Zisterzienser westlich und östlich der Oder. Frankfurt an der Oder, s. 137-146.

Wolgast, Eike 2004: Die Reformation im Herzogtum Mecklenburg. Nordost-Archiv. Zeitschrift für Regionalgeschichte NF, Bd. 13, s. 145-170. 


\section{The dissolution and subsequent fate of Medieval monasteries in Denmark and northern Germany}

There are certain differences in the building histories of monasteries in Denmark and northern Germany due to economic and political developments in the two areas during the Middle Ages. The monasteries in Denmark were founded over a very long period, although none were established in the 14th century and many in the 15th century. In northern Germany, due to the late conversion, establishment took place over a shorter period, with extensive building activity in the 13 th and 14th centuries. The major building boom seen in Denmark up to the Reformation is not evident in the north of Germany.

In the case of the Cistercian abbeys in Denmark, it is characteristic that very few of their churches ever acquired the planned length, and their cloisters were rarely completed until a late date. This contrasts sharply with the situation in northern Germany.

The nunneries in both areas lack systematic investigation. In Denmark, the nuns had, in many cases, an earlier church for their services, so it is uncertain what they themselves preferred. Whatever the situation, we can see that the nuns had their choir on a pulpit at the western end of the nave. It is also quite clear in Denmark that the main wing containing the dormitory was placed to the west. Some scholars in Germany believe that the nuns had their main wing to the east, like the monks.

The mendicant friaries in Denmark are best known from excavations, whereas in the large towns of northern Germany these still stand or are known from 19th century drawings. Very little is known about the early, closed friaries in the smaller towns. The friaries in the major Hanseatic towns had larger churches than those in Denmark and often also two cloisters.

It is quite clear from the examples of monastery dissolution that their fate at the Reformation was, to a major degree, dependent primarily on the faith of the ruler - i.e. a city council, a duke or a king - and secondly on the power this ruler had to carry out their wishes. Accordingly, we see a different pattern in relation to the Reformation in the various principalities and towns of northern Germany.

Interestingly, the Lutheran Reformation in northern Germany did not progress from west to east as is the expected norm for ideas, but rather from east to west. In East Prussia, the Reformation was introduced in 1525 , jointly and without difficulties by the new duke, the Teutonic Order, the two bishops and the other clergy.

Danzig underwent a Lutheran reformation in 1525, but due to a political change in the city council, the king of Poland had an opportunity to intervene and reverse the changes. The religious reformation in Danzig was consequently delayed by 30 years.

The Reformation in Stralsund became rather violent in 1525 but ended after a few days in a common agreement, giving consent to the Lutheran faith. The town was many years ahead of the remainder of the Duchy of Pomeranian.

In Hamburg, the citizens and the town council decided, after some debate, to adopt the Lutheran faith in 1528. A simi- 
lar, uncomplicated transition took place in Rostock in 1531 and Wismar in 1532, too. In other towns, like Lübeck and Lüneburg, there were major divisions between the town council and ordinary citizens, leading to a drawn-out process, but these towns became Protestant nevertheless in 1530-31.

The Reformation that came into force in all Pomerania was decided at a meeting, Landtag, in Treptow in 1534. That is slightly earlier than in Denmark and was without the support of the nobility. In Mecklenburg, with a divided government, there was a long period of transition, during which both faiths existed at the same time. It was first in 1549 that all Mecklenburg was declared a Protestant country with support from all the Estates.

The political situation in Denmark was clearly different from that in Mecklenburg and Pomerania. The government in Denmark was in a way more centralised. On the other hand, the king was very much dependent on his council (Rigsrådet) with a strong component of Catholic clergy. The banishing of the mendicant orders from the friaries was clearly accepted by King Frederik I and was undertaken over a short period (1528-32). However, legal suppression of the friars did not happen until 1537, when the new king, Christian III, was victorious in the civil war. There was therefore a long period when the situation was unresolved and the Reformation in Denmark was a quite extended and in some cases rather violent process. The final Reformation came much later than in most of the neighbouring states in northern Germany. Many of the monastic buildings (or more correctly friaries) were offered to the towns in which they stood, but most disappeared either at the Reformation or during subsequent centuries.

In Mecklenburg-Vorpommern, many friaries were abolished swiftly at the Reformation, which took place at rather different times. In the larger towns, they were then reused as schools and hospitals. On the other hand, it seems that the preserved examples are better known than those in Denmark, while in Farther Pomerania most have been lost over time.

As for the landowning monasteries in rural areas, there are few well-preserved examples in either Denmark or northern Germany. But as a result of excavations and other investigations, we have supplementary information for many existing monastic churches and buildings. Due to the way in which the Reformation was undertaken, it seems that the nunneries are best preserved in Mecklenburg and Pomerania, where many continued as a Protestant Damenstift, while more survives of the male monasteries in Denmark.

As for the physical remains of the monasteries in Mecklenburg-Vorpommern and in Medieval Denmark, there are now not many completely preserved Medieval monasteries, almost 500 years after the Reformation; there are even fewer in Farther Pomerania. But all in all, and looking across borders, we have, however, a great deal of information on the layout of Medieval monasteries in northern Europe - far better than in many Catholic areas with Baroque modernisations.

Hans Krongaard Kristensen Institut for Kultur og Samfund Aarhus Universitet 